\title{
Teachers' perceptions of the effectiveness of the art education preparation program in Kuwait
}

\author{
Ghadeer AlHaddad
}

Follow this and additional works at: https://researchrepository.wvu.edu/etd

\section{Recommended Citation}

AlHaddad, Ghadeer, "Teachers' perceptions of the effectiveness of the art education preparation program in Kuwait" (2014). Graduate Theses, Dissertations, and Problem Reports. 7299.

https://researchrepository.wvu.edu/etd/7299

This Dissertation is protected by copyright and/or related rights. It has been brought to you by the The Research Repository @ WVU with permission from the rights-holder(s). You are free to use this Dissertation in any way that is permitted by the copyright and related rights legislation that applies to your use. For other uses you must obtain permission from the rights-holder(s) directly, unless additional rights are indicated by a Creative Commons license in the record and/ or on the work itself. This Dissertation has been accepted for inclusion in WVU Graduate Theses, Dissertations, and Problem Reports collection by an authorized administrator of The Research Repository @ WVU.

For more information, please contact researchrepository@mail.wvu.edu. 


\title{
TEACHERS' PERCEPTIONS OF THE EFFECTIVENESS OF THE ART EDUCATION PREPARATION PROGRAM IN KUWAIT
}

\author{
Ghadeer AlHaddad
}

Dissertation submitted to the College of Human Resources and Education at West Virginal University In partial fulfillment of the requirements For the degree of

Doctor of Education in Curriculum and Instruction

\author{
Joy Faini Saab, Ed. D. Chair \\ Patricia Obenauf, Ed. D \\ Samuel Stack, Ph. D \\ Malayna Bernstein, Ph. D \\ Victoria Fergus, Ph. D \\ Department of Human Resources \& Education \\ Morgantown, West Virginia \\ 2014
}


UMI Number: 3618080

All rights reserved

INFORMATION TO ALL USERS

The quality of this reproduction is dependent upon the quality of the copy submitted.

In the unlikely event that the author did not send a complete manuscript and there are missing pages, these will be noted. Also, if material had to be removed, a note will indicate the deletion.

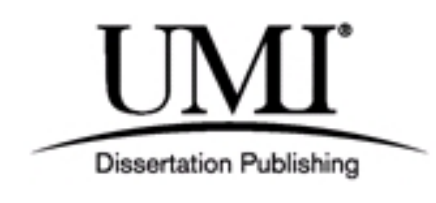

UMI 3618080

Published by ProQuest LLC (2014). Copyright in the Dissertation held by the Author.

Microform Edition () ProQuest LLC.

All rights reserved. This work is protected against unauthorized copying under Title 17, United States Code

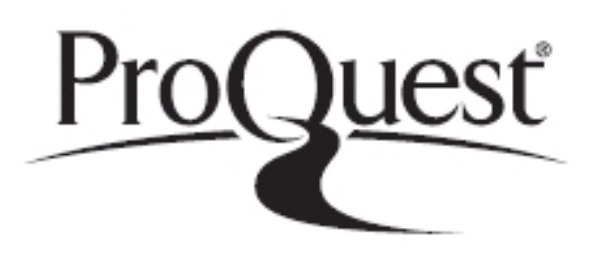

ProQuest LLC.

789 East Eisenhower Parkway

P.O. Box 1346

Ann Arbor, MI 48106 - 1346 


\begin{abstract}
TEACHERS' PERCEPTIONS OF THE EFFECTIVENESS OF THE ART EDUCATION PREPARATION PROGRAM IN KUWAIT
\end{abstract}

\author{
Ghadeer AlHaddad
}

This study was designed to investigate how pre-service, beginners, and advanced art teachers in Kuwait viewed their teacher preparation program by describing and evaluating its effectiveness. To examine the issues of art teacher training and current teaching, this study used quantitative and qualitative research approaches. The study included a qualitative document analysis and a quantitative survey questionnaire of preservice art education teachers who have completed their classroom observation at the end of the fourth year at the College of Basic Education (CBE), beginning art education teachers who are teaching in the first of their second year at the Ministry of Education in Kuwait (MOE), and advanced art teachers who are ready to teach in the beginning of their fourth year at the Ministry of Education in Kuwait (MOE), in light of a description of the art education program in the College of Basic Education from which the teachers graduated.

The purposes of this research study are to view, examine, and investigate the perceptions of pre-service, beginners, and advanced art teachers about the effectiveness of the teacher education program in the State of Kuwait, and to offer suggestions for program improvement and the design of local curricular guidelines for the future of the art teacher program. 


\section{ACKNOWLEDGMENTS}

I would like to thank my committee members, Dr. Joy Faini Saab, Dr. Patricia Obenauf, Dr. Samuel Stack, Dr. Malayna Bernstein, and Dr. Victoria Fergus for sharing their knowledge with me and assisting me throughout my doctoral studies. A special thank you goes to my advisor, professor Dr. Joy Faini Saab, for guiding and supporting me over the years. I would also like to express my deep appreciation to all the art teachers in the public schools and all art students in the college in Kuwait who took time from their busy schedules to respond to the survey.

I would especially like to thank my family, my dear father and mother, brothers and sister for their love and care and for all the support they provided. Last, but not least, I am thankful to my friends, who have been sources of assistance and guidance throughout the completion of this dissertation. 
Table of Contents

\begin{abstract}
Dedication

Table of Content

Chapter 1: Introduction
\end{abstract}

Content and Background

Education in Kuwait

Art Teacher Education in Kuwait

Purpose of the Study

Problem Statement

Research Strategy and Rationale

Research Questions

Brief Overview of the Study

Limitations of the Study

Definition of terms

Summary

Organization of Dissertation Chapters

Chapter 2: Literature Review

Teacher Education and the Art Teacher

How well pre-service art teachers prepared

The role of the university faculty 
Teacher preparation programs and field experience courses

Description of Art Education Programs

Pre-service and in-service art teachers

Summary

Teachers' Problems and Concerns

Well-prepared teachers are more likely to remain in teaching

Good quality teacher preparation helps develop essential knowledge and

teaching skill

Well-prepared teachers produce higher student achievement

The Literature Suggestions

Building a Collaborative Model of Art Teacher Preparation: Cognitive

Coaching: A Model for Collaborative Learning

The role of the student teacher supervisor: Mentoring Model

Conclusion

Chapter 3: Methodology

Introduction

Research Questions

The research proceeding

Overview of the study

Research Strategy and Rationale

Human Subjects Review - IRB

Sources of Data

Population 


\section{Participants}

Procedure

Settings

Instrumentation

Survey questionnaire

Document analysis

Data Collection

Design

Validity

Reliability

The sample selected and group format

Data Analysis

Quantitative Data Analysis Process

Qualitative Data Analysis Process

Time schedule

Summary

Scope and limitation of the study

Chapter 4: Results

Part One: Demographic Data of Participants

Part Two: Art Teachers' perceptions of preparedness and Training Experiences

Pre-service art teacher's perceptions of preparedness

In-service Beginner art teachers' perceptions of preparedness

In-service Advanced art teachers' perceptions of preparedness 
Part Three: Art Teachers' Attitudes and Feelings

Part Four: Research Questions

Part Five: Qualitative Data Analysis

Chapter 5: Conclusions and Discussion if the Result

Research Questions

Supporting Question Number 1

Supporting Question Number 2

Supporting Question Number 3

Supporting Question Number 4

Supporting Question Number 5

Discussion, Implications, and Suggestions

Recommendations for Further research

Limitations of the Study

Summary of Conclusion

Appendix A: The IRB Approval from West Virginia University

Appendix B: Survey Questionnaire for the Pre-Service Art Teachers at the College of Basic Education in Kuwait

Appendix C: Survey Questionnaire for In-Service Art Teachers at the Ministry of Education in Kuwait

Appendix D: Cover letter Form for both the Pre-Service Art Teachers at the CBE and InService Art Teachers at the MOE in Kuwait

Appendix E: Permission letter to the College of Basic Education in Kuwait And the Approval letter from the CBE

Appendix F: Arabic Version of the Permission letter to the College of Basic Education in Kuwait and the Approval letter from the CBE 
Appendix G: Permission letter to the Ministry of Education in Kuwait and the Approval letter from the MOE

Appendix H: Arabic Version of the Permission letter to the Ministry of Education in Kuwait and the Approval letter from the MOE

Appendix I: Arabic Version of the Survey Questionnaire for the Pre-Service Art Teachers Appendix J: Arabic Version of the Survey Questionnaire for the In-Service Art Teachers

Appendix K: Arabic Version of the Cover letter Form for both the Pre-Service Art Teachers at the CBE and In-Service Art Teachers at the MOE in Kuwait

Appendix L: Arabic Version of the Consent Form for both the Pre-Service Art Teachers at the CBE and In-Service Art Teachers at the MOE in Kuwait

Appendix M: Letter of Confirmation of Translations

Appendix N: The CBE Program of Study - in Arabic

Appendix O: A Form for The MOE Numbers of Art Teachers for the 2012-2013 - Arabic

Appendix P: A Form for The MOE Numbers of Schools for the 2012-2013 - Arabic

References 


\section{CHAPTER 1}

\section{INTRODUCTION}

Excellence in education, excellence in arts disciplines, and excellence in related fields must go hand in hand in the way

of preparing teacher of art education. The task of improving art teacher preparation programmes is of central importance in the field of art education today.

Mohammed Al-Amri

Linda Darling-Hammond and John Bransford wrote in Preparing Teachers for a Changing World, the issue of the quality of preparation new teachers. They admitted it takes many years of experience to be name an expert and profession in teaching. Yet, it is important "to provide teachers with the core ideas and broad understanding of teaching and learning that give them traction on their later development" (Hammond and Bransford, 2005, p.3). In that sense, this study focused on the effectiveness of preparation programs for art education teachers in Kuwait.

The effectiveness of preparation programs for art education teachers have been identified as an important aspect of quality art education and an important factor for having well-prepared art teachers (Davis, 1990; Day, 1997; Galbraith, 1990, 1995; Zimmerman, 1994b, 1997; Harrell, 2007; Al-Najar, 2001; Darweesh, 2010; Bufarsan, 2000; al-Hamad, 1986; Al-Ahmad, 1980; Al-Amri, 2010; Smith, 2010). Researchers in the field of art education have determined that doing more research on the preparation of 
art teachers. It is necessary that art teacher preparation should be central to art education research (Al-Najar, 2001; Al-Amri , 2010; Beudert, 2006; Davis, 1990; Day, 1997; Galbraith, 1990, 1995; Galbraith \& Grauer, 2004; Sabol, 2004; Thurber, 2004; Zimmerman, 1997, 2004; Harrell, 2007; Darweesh, 2010; Bufarsan, 2000; al-hamad, 1986; Al-Ahmad, 1980).

In that context, this study reported on the effectiveness of existing art education programs in the College of Basic Education in the State of Kuwait based on the perceptions of pre-service, beginners and advanced art teachers, who teach visual art curricula in the public schools of the state of Kuwait. Perceptions of those who graduated from the programs and currently are teaching in the public schools and those who are in their last year of college and are ready to teach are essential to this study. These perceptions provide insight into how the art education preparation program and the field experience courses can be evaluated and how they can be improved. According to AlAmri, a supervisor for Art teacher training courses at Sultan Qaboos University (SQU), "the Art teacher preparation programmes need to be improved even where they can be described as already strong, as they need to take account of developments in Art Education as a professional field" (2010, p. 2). As Harrell stated in her study, "Examining the perceptions and concerns of beginning art teachers regarding their teaching practices in relation to their preparation to teach can help to inform and improve art education programs in colleges and universities" (2007, p. 2).

\section{Content and Background}

\section{Education in Kuwait}


As stated in Al-Najar study, "there are three basic levels of public education in Kuwait - elementary, intermediate, and secondary. Each level involves four years of study, and schooling usually begins at age six. There are separate schools for boys and girls at these three levels. Students who complete their basic education can continue on to higher education" (2001, p.13).

In Kuwait, there are two major higher educational institutions: Kuwait University and the Public Authority for Applied Education and Training (Al-Najar, 2001). The College of Basic Education (CBE) is offered through the Public Authority for Applied Education and Training. The CBE is the only college in Kuwait that provides a teacher preparation program including the art teachers preparation. It has two separated campuses: one for male and one for female. In 1978, an art education program was added to the CBE (Al-Najar, 2001). In 1986, the College of Basic Education (CBE) first took its name and became a four-year program leading to bachelor's degree in education (Al-Najar, 2001; Darweseh, 2010). Since then, Kuwait has an ongoing encourage improving education. Arab Gulf countries, including Kuwait, recently raised the issue of the importance of improving teacher preparation programs (Al-Ahmad, 1980; Al-Ahmad, 1986; Al-Enezi, 1999; AL-Mass, 1999; Al-Nnjar, 2001; Bufarsan, 2000; Darweesh, 2010).

Researchers in Kuwait had established and encouraged to do more research on the evaluating of the teacher preparation programs. Studies in evaluation of the different teacher preparation programs in Kuwait have been increasable enlarged in the recent years. Yet, not many studies have been focused on the evaluation of the art education teacher program. In 2001, Al-Najar conducted a research study of the first and second 
year elementary art education Kuwaiti teacher's perception of their professional preparation.

The purpose of his study was to examine beginning elementary art teachers' evaluation of the efficacy of their art teacher preparation program at the CBE in Kuwait. Al-Najar study evaluated the CBE art education program through first and second art teachers feeling about their preparation in the three areas: content knowledge, curriculum and assessment. As recommended by Al-Najar, the CBE should strengthen the three areas with more practice experience (Al-Najar, 2001). His study explored how beginning art teachers were well prepared to teach based on three areas in art education: content knowledge, curriculum, and assessment. The result of the study found that the first and second year art teachers felt well prepared and successful in all the three areas (Al-Najar, 2001).

Since there is only one program for preparing art teachers in Kuwait, this study added more knowledge to the continuous evaluation process, and added more evaluation and knowledge to CBE art teacher program in Kuwait. In this study, a survey instrument was adapted and modified from Harrell's study (2007). A different process of evaluation and different contents were used in this study to add more knowledge to the evaluation. The purpose of this research study was to view, examine, and investigate the perceptions of pre-service, beginners, and advanced art teachers about the effectiveness of the teacher education program in the State of Kuwait and to provide comparison between the three groups. This study focused on the effectiveness of the art teacher program, the effectiveness of the field experience-training course in the CBE art teachers program, and the influence of the university faculty and the supervisors to the pre-service art teachers. 
The reason behind the program evaluation is to have a more effective program that will benefit the art teachers. Students who graduated from the CBE could apply to teach art at the MOE. According to the MOE, Kuwait had 807 public schools (elementary, middle, and high schools) and 2446 male and female art teachers. Those schools are located in the five districts (Hawalii, Al-Aasma, Al-Jahra, Al-Ahmedi, Mubarak Al-Kbeer, and Al- Farwaniya). This study focused only on Al-Aasma and Hawalli. Al-Aasma had 102 schools and 429 art teachers. Whereas Hawalii had 89 public schools (elementary, middle, and high schools) and 407 art teachers (Ministry of Education in Kuwait, 2013- Appendix O, P).

\section{Art Teacher Education in Kuwait}

The College of Basic Education in Kuwait offers a four-year bachelors degree in education and allows those who graduated from the CBE to work as teachers in both public and special schools in Kuwait. The CBE offers several teacher preparation programs such as art education, Arabic language, English language, interior design, Islamic education, kindergarten, curriculum and instruction, mathematics, music education, physical education and sport, science education, special education, and social studies (College of Basic Education website).

According to the CBE program for art education, to major in art education, a student in Kuwait is required to complete 130 credits in art education. These required credit hours are distributed as follows: 30 credits for general education courses and elective courses, 69 credits for major requirement courses (Studio Art, Art Production, Aesthetics and Art Criticism) 11 credits for field training courses ( 9 credits for school 
field-training, 2 credits for a seminar course), 20 credits for minor courses in Interior Design (College of Basic Education, 2013 - Appendix N).

Students who complete all the requirements can be successfully employed in the Ministry of Education and practice their teaching. However, "the majority of the CBE graduates face several problems due to the lack of knowledge and skills to teach certain content areas of the art curriculum" (Darweesh, 2010, p. 3).

Some Kuwaiti beginner art teachers struggle in their first year of teaching, while others quit and leave the profession. The lack of important courses, such as the preparation courses, is the reason behind the quality of the program (Mohammad, 2007). Researchers and studies in Kuwait pointed that this problem occurs because some necessary courses are not included in the pre-service art education program (Al-Enezi, 1999; Darweesh, 2010; Al-Mass, 1999; Al-Muhanna, 1989; Al-Ahmad, 1980; Al-Ahmad, 1986; Al-Najar, 2001; Al-Sayegh, 1998; Alnajdi, 2001). They all agreed that the preservice art education program in Kuwait needed to be examined, investigated, and evaluated in order to help Kuwaiti beginner art teachers to start their professional teaching successfully. They also suggested that the College of Basic Education (CBE) should be examined and reviewed (Al-Muhanna, 1989; Al-Ahmad, 1980; Al-Ahmad, 1986; Al-Najar, 2001; Al-Sayegh, 1998; Al-Enezi, 1999; AL-Mass, 1999; Alnajdi, 2001). Darweesh clarified that the CBE preparation courses did not fully serve the curriculum that the Kuwaiti Ministry of Education (MOE) requires art teachers to teach (2010). Therefore, beginner art teachers struggle and face a serious problems because what they are prepared to do as pre-service students did not meet what they are seeing and facing in their everyday teaching practice. 


\section{Purpose of the Study}

In 2001, Al-Najar conducted a study in evaluating the CBE art education program through first and second art teachers feeling about their preparation in the three areas: content knowledge, curriculum and assessment. As recommended by Al-Najar, the CBE should strengthen the three areas with more practice experience (2001).

This study added more knowledge to the continuous evaluation process. The purpose of this research study was (1) to view, examine, and investigate the perceptions of pre-service, beginners, and advanced art teachers about the effectiveness of the teacher education program in the State of Kuwait and provided comparison between the three groups, (2) to offer suggestions for program improvement and the design of local curricular guidelines for the future of the art teacher programs.

Furthermore, this study is a foundation for future research in art education programs. This study offers some recommendations to help improve the art education teacher preparation program in Kuwait. Research studies suggested that more research is needed on how well beginner teachers (Galbraith, 1997; Al-Ahmad, 1980; Al-Ahmad, 1986, Al-Muhanna, 1989; Al-Enezi, 1999) and art teachers manage their teaching practices as they begin their first years of teaching (Duncum, 2003; Harrell, 2007; Smith, 2010).

A quantitative survey questionnaire was used to investigate how pre-service, beginners, and advanced teachers feel about the effectiveness of the teacher education program in preparing them for their occupations (Appendix B \& C).

The data, which was collected from these questionnaires, provided useful 
information for program improvement and the design of local curricular guidelines for the future of art teacher programs. This study provided insight into how the art education teachers preparation program can be improved.

Art education is offered only in the College of Basic Education (CBE), so many students apply to the CBE to be in the art education program. Therefore, those art teachers can work in the ministry of education in Kuwait MOE. On the other hand, Kuwait University also offers important art education courses in the college of education, curriculum and instruction department. These courses are designed to help all the students who are currently enrolled in the college of education and are preparing to be teachers and teach in public schools in Kuwait. In art education classes, students learn the importance of art education and how to apply, adapt, and integrate art education to other educational curriculums (Kuwait University). In that context, this research study will help both the College of Education (KU) and the College of Basic Education (CBE) and will support their art education courses and programs. Additionally, this study will reflect great amount of knowledge that will help Kuwaiti society, Kuwaiti students and art teachers.

This study addressed the issue of existing art education-preparation programs. This study answered the question "what prospective teachers need to learn and how they may best be enabled to learn it?" (Hammond and Bransford, 2005, p. 4). Additionally, this study provided suggestions for improving the curriculum for the preparation of art educators. This research study helped the educational development of the College of Education at Kuwait University and the College of Basic Education at the Public Authority for Applied Education and Training in the state of Kuwait. 
A review of the literature related to the training of teachers and art teachers, and the experiences of pre-service and novice (in-service) teachers was conducted to gain insight into what they learned in their pre-service field experience courses and in the teacher preparation programs in general, and the experiences of beginner teachers and their preparation to teach in their first years.

\section{Problem Statement}

This study took place in Kuwait. This is an important site for this research, because there is only one art teacher program in Kuwait, and it has not had an external evaluation in recent years.

Also, this study addresses the issues that influence the preparation and the quality of art teachers. Based on my own experience, I enrolled in the college in 2001, graduated in 2005, and was an art teacher in Kuwait in 2005. Even though I was aware of the art education materials, I felt stressed and unprepared. I knew my subject very well, but I did not feel prepared to teach and deliver it to my students.

CBE prepares students to teach elementary students, but not middle or high school students. The courses provided in the art teacher preparation program are oriented towards elementary school students only with only 9 credit hours (Appendix N) whereas some art teachers decided to teach at middle schools or high schools.

The CBE program offers a strong program in art teacher education. The art studio courses, art history, art aesthetics, art criticism, and art curriculum are informative and knowledgeable. This study was concerned about the field experience courses, which are only a few credits hours and only focus on elementary students. Some art teachers choose 
to teach at elementary schools, while others transfer to middle or high schools within their first or second years of teaching. The study desired all art teachers, who graduate from the college to be well prepared and able to work satisfactorily in their jobs and continue their service as long as possible. Whether they are teaching in elementary, middle or high schools. I believe pre-service art teachers should have a chance to observe, practice teaching, and trained to teach in elementary, middle, and high schools.

Some art teachers graduate from the college of education and are well prepared to teach art in schools; others are not well prepared, even though they graduated from the same program. "Many of the graduates from the pre-service art teacher program are not prepared to teach some art education classes" (Darweesh, 2010, p. 5). It is important to identify the factors that impact the preparation in Kuwait, and why some art teachers are successful in teaching and are being in-service, while others quit their art-teaching career.

This study asked this question: How do pre-service, beginner, and advanced art teachers in Kuwait describe and evaluate the effectiveness of their teacher preparation program?

The first step towards improving the art teacher training programs is to determine perceptions that are needed for art teachers (Buldu, 2005; Duru, 2006). This study gathered this information by asking three groups to reflect upon their experience teaching in schools and whether what they were taught in the College of Basic Education training programs met their needs on the job. The three groups are: (1) pre-service art teachers who have completed their classroom observation at the end of the fourth year at CBE, (2) beginning art education teachers who are teaching in the first of their second year at the Ministry of Education in Kuwait, and (3) advance art teachers who are ready to teach in 
the beginning of their fourth year at the Ministry of Education in Kuwait.

According to Al-Najar, "Teachers' perceptions play a significant role in providing feedback and recommendations to improve the educational process; in particular, to their preparation program at their colleges or universities"(2001, p.40). He added that art teachers "can provide insights into what they need, since they are the ones who face the challenges of the classroom. Their individual experiences provide a foundation of knowledge" (2001, p.41). Harrell indicated, "Examining what teachers say they valued in the programs they attended and what they feel was missing in light of their teaching situation, art educators can gain a better understanding of the type of program that will support quality art education instruction in today's schools.” (2007, p. 2). Perceptions of those art teachers in Kuwait helped to gather the information needed for how well the art teacher preparation program prepared them to teach art, and whether what they were taught in the College of Basic Education training program met their needs in their jobs.

\section{Research Strategy and Rationale}

Beginner art teachers face serious problems in their first years of teaching (Duru, 2006). Some beginner art teachers decide to leave their jobs, while others decide to switch or transfer to another job. Feeling unprepared is one of the serious reasons that most art teachers leave and quit their jobs. Moreover, unprepared art teachers will affect negatively on the students understanding of the materials and on students' achievements. Linda Darling-Hammond and John Bransford stated in there book Preparing Teachers for a Changing World that "we seek to describe the initial understanding that teachers need to serve adequately the very first students they teach" (Hammond and Bransford, 
2005, p. 3). The questions to be asked are why do some art teachers stay in their positions and teach, while others quit and who is responsible for preparing future art teachers.

According to many experts in the field of art education, well-prepared art teachers are those who are successful in the field of teaching, have a positive impact on their student's achievements, and are more likely to stay in their jobs. Therefore, the art teacher preparations programs need to investigate and evaluate to ensure their efficiency for preparing future art teachers. One way to investigate the efficiency of the program is by asking art teachers' perceptions (Harrell, 2007).

In short, the core of this study was to examine the perceptions of the pre-service, beginners, and advanced art teachers to give insight into how well they feel prepared, how effective was their preparation program, and how the program prepare them to teach effectively during first years of their teaching.

\section{Research Questions}

How do pre-service, beginner, and advanced art teachers in Kuwait describe and evaluate their teacher preparation program?

The supporting questions:

1. What are the perceptions of pre-service, beginner, and advanced art teachers in Kuwait regarding the theoretical and practical training they received in their teacher education program?

2. What are pre-service, beginner, and advanced art teachers in Kuwait feeling regarding how well they think their education prepared them for their current positions? 
3. What are pre-service, beginner, and advanced art teachers in Kuwait feeling regarding the effectiveness of their field experience courses and how it prepared them for their teaching practice during their first years?

4. What are the perceptions of pre-service, beginner, and advanced art teachers in Kuwait regarding what beginner art teachers should know and be able to do and how well they thought their education prepared them for their current position?

5. What are pre-service, beginners, and advanced art teachers in Kuwait feeling towards the most influencing person during their teacher training?

The research followed this schedule:

1. Reviewed of the literature to determine the scope of the research and to define appropriate questions.

2. Developed a survey based on the review of literature, Kuwait culture, and based of the certification of the $\mathrm{CBE}$ at the state of Kuwait to draw out and explore beginner art teachers' perceptions of their preparedness to teach art.

3. Evaluated and compare the data thematically in terms of the questions asked and the themes that emerge.

4. Drew conclusions from the data and make recommendations for art teacher preparation program at CBE in the State of Kuwait.

\section{Brief Overview of the Study}

This study gathered data on teachers' perceptions of the effectiveness of art education teachers preparation program in Kuwait through a survey questionnaire of pre- 
service art education teachers who have completed their classroom observation at the end of the fourth year at $\mathrm{CBE}$, beginners art education teachers who are teaching in the first of their second year at the Ministry of Education in Kuwait, and advanced art teachers who are ready to teach in the beginning of their fourth year at the Ministry of Education in Kuwait. Survey developed in light of the literature review framework.

The survey questionnaire was adapted and modified from Harrell (2007) dissertation, and was modified to be based on the issues that related to teacher preparation and training courses as discussed in the literature review (Blackman, 1977; Chapman, 1979; Darling-Hammond, Chung, \& Frelow, 2002; Jeffers, 1996; Harrell, 2007; Darweesh, 2010; Bufarsan, 2000) and based on the culture, tradition, religion, and CBE requirement to obtain a certificate in teaching art in the state of Kuwait.

The purpose of the survey questionnaire was to gather data on the perceptions of the pre-service, beginner, and advanced art teachers to give insight into how well they feel prepared, how effective was their preparation program, how the program prepare them to teach effectively during first years of their teaching, and to determine what works, what does not work, and what more is needed to add the quality to the art education preparation program.

The survey questionnaire was printed and handed to all art teachers in Kuwait who have completed their classroom observation at the end of the fourth year at College of Basic of Education (CBE), who are teaching in the first of their second year at the Ministry of Education in Kuwait (MOE), and who are ready to teach in the beginning of their fourth year at the Ministry of Education in Kuwait (MOE) (Appendix B \& C).

Data was analyzed through quantitative survey method. The data, which was 
collected, will help for further research studies.

\section{Limitations of the Study}

Unlike some of the other subject areas in the field of education where a strong research base and references do exist internationally, research into the preparation of the Kuwaiti art teachers is more limited. This study was limited by the lack of resources in Kuwaiti literature regarding pre-service programs and art teachers pre-service programs. Because the study was conducted in the State of Kuwait, the findings may not be generalized to other countries and their art teacher preparation programs. Culture, religion, and diversity were major considerations within this study.

The research study was limited to Kuwaiti art teachers. This study was narrowed to include three groups of participants so that there were no large gaps since the art teacher graduated and being in the field. Also, other factors would not affect the quality of well prepared, such as the more time spent in the field the more being professional.

This study was limited to the art education preparation program and art educators in Kuwait. This study was limited to two districts (Al-Aasma and Hawalli) of the five districts in Kuwait (Al-Jahra, Al-Ahmedi, Mubarak Al-Kbeer, and Al- Farwaniya). This study examined only the perceptions of the art teachers who were in their last year at the CBE and those who were working in the MOE at only Al-Asma or Hawalii. This study focused only on art teacher's perceptions toward their preparations efficiency.

\section{Definition of terms}


For the purpose of this study, terms were defined as follows:

Arts Education - Skill based instruction in various art disciplines (New York statewide Local Capacity Building Coordinators, 2005).

Arts in Education - Students and teachers partner with artists and arts and cultural institutions to integrate the arts (New York statewide Local Capacity Building Coordinators, 2005).

Art Education Program - A program of study in a college or university that leads to certification to teach art in schools, grades K-12 (Harrell, 2007).

Art Educator - A faculty member in a university or college who trains a prospective teacher in the visual arts in preparations to teach art K-12 (Harrell, 2007).

Art Teacher - A teacher of visual arts K through 12 (Harrell, 2007).

Beginning Teacher $-\mathrm{A}$ teacher who has three or fewer years of full-time teaching experience (Harrell, 2007).

CBE - College of Basic of Education in Kuwait.

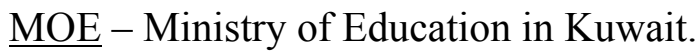

Perception - For the purpose of this study, it is believed or opinion hold by many people and based on appearances (Cambridge dictionary).

Pre-service Teacher - A teaching candidate receiving training in an art education program including the student teaching practicum and prior to employment into their first teaching job (Harrell, 2007).

Quality teachers - teachers who positively influence student learning (J. Cooper and A. Alvarado, 2006). 


\section{Summary}

This chapter presented an introduction, the purpose of the study, problem of the study, research strategy and rational, research questions, overview of the study, definition of terms, limitations of the study, and summary of the study. It also presented a brief background and history of art teachers and art education at the College of Basic Education in the State of Kuwait, and art teachers and art education in the United States of America.

This research study investigated the efficiency of the art teachers preparation program in the state of Kuwait by asking pre-service, beginner, and advanced art teachers in the State of Kuwait to describe and evaluate their teacher preparation program. Their experiences, perceptions were gathered through quantitative survey questionnaires. The data for this study were generated from the answers of the survey. The data used to highlight the art teacher programs' strengths and weaknesses, and used to evaluate the effectiveness of the field experience courses in program.

Results of this study offer suggestions and improvements for existing art teacher program in the state of Kuwait. The next chapter includes the review of the related literature.

\section{Organization of Dissertation Chapters}

Chapter Two provides a review of the literatures of the teacher education and art teachers preparation programs worldwide with a focus on literature in the United States of America and in the State of Kuwait. 
Chapter Three describes the methodology of the research study. It addresses the sources of data for the study such as the data analysis and the survey, and includes the selection of the participants, the process and setting, design of the study, and data analysis. Validity and reliability issues are also addressed. Chapter Four presents the results, findings, and the conclusion of the study. Chapter Five provides discussion and suggestions for future studies. 


\section{CHAPTER 2}

\section{LITERATURE REVIEW}

\section{Teacher Education and the Art Teacher}

According to many researchers, a large number of beginning teachers are either struggling with their teaching practice or leaving their teaching jobs within their first years of teaching (J. Cooper and A. Alvardo, 2006). Teaching effectiveness and teaching quality are of interest to many academics and educational researchers (Unrath and Kerridge, 2009). Studies and researchers are shifting toward investigating the effect of preparation programs on students' effectiveness for those who are planning to become art teachers (Degge, 1987; Al-Muhanna, 1989; L. Darling-Hammond; R, Chung; F, Frelow, 2002; Duncum, 2005; Al-Amri, 2010).

An increasing number of researchers are asking whether and how teacher education preparation programs make a difference in teacher quality in teaching effectiveness, and in how long they remain in teaching (Degge, 1987; Al-Muhanna, 1989; L. Darling-Hammond; R, Chung; F, Frelow, 2002; Duncum, 2005; Al-Amri, 2010). Is it the teacher preparation programs that need to be investigated? An important question was asked by Darling-Hammond in an article in a journal of teacher education, "Does teacher education influence what teachers feel prepared to do when they enter the classroom?" (2002). Does feeling well-prepared matter in the field of teaching?

The first few years of teaching and being in a classroom are sensitive times for teachers. Some teachers struggle in their first years of teaching, while others are more 
successful in the field. Galbraith (as cited in Harrell, 2007) encouraged doing more research on preparing teachers as they begin their first years of teaching. It is no wonder that researchers are asking to do more research on teacher preparation programs, teacher perceptions and effectiveness, and quality of teaching and learning (Harting-McChesney, 2008).

According to many researchers, how well teachers feel prepared is the key to becoming successful teachers. Researchers and educators in the field of education think that it is important to investigate teacher education preparation in order to reach the goal of effective teaching and learning. Many researchers in the field of education have encouraged more research about student teaching (Brimfield \& Leonard, 1983; DarlingHammond, 1998, 2007; Dodds, 1985; Fenimore-Smith, 2004; Lui, 2003; McDermott, 2002; Yost, 1997; Al-Najar, 2001; Al-Muhanna, 1989).

Like general teacher education, art education must consider the importance of teacher preparation programs. Many recent researchers in the field of art education have suggested doing more research on preparing art teachers (Al-Amri , 2010; Al-Ahmad, 1980; Beudert, 2006; Davis, 1990; Day, 1997; Galbraith, 1990, 1995; Sabol, 2004; Thurber, 2004; Zimmerman, 1997, 2004). Preparation of art teachers is considered one of the important factors for better art education (Al-Najar , 2001; Al-Amri , 2010; Davis, 1990; Day, 1997; Galbraith, 1990, 1995; Zimmerman, 1997; Degge, 1987). In a recent study, Milbrandt indicated that teaching experience is a powerful influence on art education students (2006). Field experience courses and preparation courses are essential to art education students. The more experience they have, the more they feel confident and well prepared to teach. 
According to the findings of the literature review, the issue of preparing a good art teacher is an international concern. In Kuwait, Al-Najar pointed that experiences are important in formulating the perspectives of the pre-service teacher course (2001). He added, "Teachers" perceptions play a significant role in providing feedback and recommendations to improve the educational process; in particular, to their preparation program at their colleges or universities" (Al-Najar, 2001, p. 40).

According to Day (as cited in Harrell, 2007), preparing art teachers is one of the most important issues related to art education. The National Art Education Association (NAEA) recommended that researchers examine pre-service and in-service teacher education to improve art education (as cited in Harrell, 2007). When we ask beginning art teachers about their experience and perceptions of their training programs, we generate good data that we can depend on for changing and improving the institution preparation programs (Al-Najar, 2001; Harrell, 2007; Al-Amri, 2010).

For reaching effective teaching and learning, this study used a framework that adapted from John Dewey, Ball and Cohen, and Hammond and Bransford. John Dewey's theory is students centered learning. In his book the Child and the Curriculum, Dewey clarified that an ideal curriculum must meet the child's need. The curriculum should provide the students the opportunity to learn by exploring their experience and connect what they learned to their world (1902). As cited in Preparing Teachers for a Changing World, "It is similar as well to Ball and Cohen's representation of instruction as the interactions of teachers, students, and content, in environments that influence all of these" (Hammond and Bransford, 2005, p. 10). Hammond and Bransford used a framework for understanding teaching and learning. It highlighted three general areas that are important 
for any teachers. These areas focus on knowledge, skills, and dispositions. It stated that any teacher should acquire

- Knowledge of learners and how they learn and develop within social contexts,

- Conception of curriculum content and goals: an understanding of the subject matter and skills to be taught in light of the social purpose of education, and

- An understanding of teaching in light of the content and learners to be taught, as informed by assessment and supported by classroom environments.

This framework allows teachers to connect what they learned, reflect on their practice, and improve their profession teaching.

In Kuwait during the 80s and 90s, many Kuwaiti researchers conducted their studies in the purpose of evaluation or examined the teacher education in Kuwait (Alenezi, 1998; Al-Muhanna, 1989; AL-Mass, 1999). Alenezi' study (1999) focused on the historical development and progress of art education in Kuwait from 1912 until 1997. The purpose of the research was to light the importance of art education in Kuwait and how it effected and improved Kuwaiti society, educate its citizens, raise awareness of the culture, and move the country from a traditional framework into a modern one.

In 2000, Bufarsan conducted research study titled Curriculum Analysis in Teacher Preparation Programs at the College of Basic Education in Kuwait. The purpose of his study was to prepare quality teachers. This study described and compared the stated goals 
and perceived outcomes of teacher preparation programs at the College of Basic Education (CBE) in Kuwait. The study assessed the perceptions of knowledge and skills of student teachers, new teachers, and instructors toward the existing program at the CBE in Kuwait. The literature reviewed recommendations from the United States to develop a framework of five common standards for analyzing the teacher preparation curriculum: content knowledge, instruction, diversity, professional development, and field work. In addition, research and evaluation of teacher education programs were reviewed for perceptions of student teachers and new teachers about their preparation and for methodology (Bufarsan. 2000).

In 2001, Al-Najar and Alnajdi examined and recommended to do more research studies in the field of art education in Kuwait. Al-Najar research study of the first and second year elementary art education Kuwaiti teacher's perception of their professional preparation examined beginning elementary art teachers' evaluation of the efficacy of their art teacher preparation program at the CBE in Kuwait. The study explored how beginner art teachers were well prepared to teach based on three areas in art education: content knowledge, curriculum, and assessment. The result of the study found that the first and second years art teachers felt well prepared and successful in all the three areas (2001). In 2010, Darweesh also examined the knowledge, skills, and experiences in the enameling arts and the attitudes and perceptions of in-service and preservice Kuwaiti art teachers, art supervisors at the Ministry of Education, and art education faculty members at the College of Basic Education (CBE) and Kuwait University (KU) about what they believed pre-service art teachers should know and be able to do in order to teach the enameling arts in Kuwait. The result of his study found 
that most of the respondents revealed limited knowledge and skills and modest experiences in the enameling arts. He added that a revision to the current art education curriculum at the CBE is needed (Darweesh, 2010). This study added more knowledge to the continuous evaluation process.

Mohammad (2007) conducted a research study that was focused on the lack of professional development systems of architectural students and pre services students in Kuwait. The research focused on knowledge and skills needed and recommended for require internship for students before graduation. This study assessed the importance of perceived value, perceived need, and recommended time period of internship programs in Kuwait and proposes recommended knowledge areas/skills for this architectural internship experience, before and after graduation from college. This research study focused on architecture pre service students and recommended the internship course. He clarified the important of the internship course before graduation, which is as important as the field experience courses for the pre-service art teachers in Kuwait (Mohammad, 2007).

The purpose of this research study was to view, examine, and investigate the perceptions of pre-service, beginner, and advanced art teachers about the effectiveness of the teacher education program in the State of Kuwait and to provide comparison between the three groups. This study focused on the effectiveness of the art teacher program, the effectiveness of the field experience-training course in the CBE art teachers program, and the influence of the university faculty and the supervisor to the pre-service art teachers.

The review of the literature revealed that art teacher preparation programs 
internationally affect the quality of art programs and the quality of art teachers. Research considered these factors: (1) how well pre-service art teachers were prepared (Al-Najar, 2001; Darweesh, 2010, Al-Amri, 2010); (2) the role of the university faculty (Milbrandt, 2006; Harrell, 2007; Zimmerman, 1997); and (3) field experience courses and teacher preparation programs (Harrell, 2007; Al-Ahmad, 1980; Susi, 1992). According to experts in the field, each of these factors has an influence on the effectiveness of teacher training programs.

How well pre-service art teachers prepared

To know about how well the pre-service art teachers are prepared, a researcher looked at art teachers' perceptions toward the program (Buldu, 2005). Perceptions are very important for those who are in the art field (Stuckhardt, 1976; Vance, 1989; Buldu, 2005). It is important to consider the perceptions of art students. Darling-Hammond listed teacher preparation and experience as important factors in teacher effectiveness. There is an internationally growing interest in studying pre-service and in-service art teachers' perceptions of their art teacher preparation programs.

Do teachers' perceptions of their preparation programs make a difference? Why do we ask about and examine teachers' perceptions rather than directly measure their effectiveness?

According to Darling-Hammond, Chung, and Frelow, "Teachers' perceptions may depend on both individual differences and contextual differences (e.g., the kind of school where a teacher begins teaching, whether the teacher is working in his or her field of preparation, what kinds of supports are available).” They concluded that teachers' 
perceptions of their preparedness may or may not be related to their actual teaching effectiveness (Darling-Hammond; Chung \& Frelow, 2002). However, teachers' certification status is related to student learning achievement (Darling-Hammond). Therefore, research is needed on the relationship between teachers' perceptions, programs and preparation, and teaching quality and effectiveness.

Knowing about teachers' perceptions may also give us more information about teachers' education, teaching effectiveness, and the future of teachers' occupations. In a recent article, a group of educators stated, "Although teachers' perceptions do not allow a direct examination of teacher effectiveness, they do allow us to explore the relationships between teachers' views of their preparedness and their sense of teaching efficacy as well as their views of their entry pathway and their plans to remain in teaching" (DarlingHammond; Chung \& Frelow, 2002). In summary, teachers' perceptions regarding their teacher preparation programs are important to the field of education in general and to teachers in specific.

A recent study by a group of researchers and educators in New York City found that first-year teachers who are less effective than their peers in teaching are leaving their teaching jobs within their first five years (Boyd; Grossman; Lankford; Loeb \& Wyckoff, 2009). Another international survey study by Monsivais examined 1,252 Mexican American educators' perceptions regarding their professional preparation. The study found that $41 \%$ of Latino teachers felt well prepared to teach their students, whereas $51 \%$ of the respondents said that they did not feel well prepared and that they planned to leave classroom teaching within the next five years. Also $24 \%$ replied that they would likely 
seek an occupation outside education (1990). The issue of feeling unprepared and leaving the teaching profession is similar internationally.

In summary, it is important to examine teachers' perceptions regarding their preparation programs in order to understand, evaluate, and develop the actual program to have the best outcome (future teachers) that meets the goals of better education and learning. Teachers who feel well prepared are more likely to feel confident about the ability to achieve their teaching goals (Darling-Hammond; Chung \& Frelow, 2002). They added that teachers' sense of efficacy is related to perceptions about how well they were prepared (2002).

\section{The role of the university faculty}

Second, the role of the university faculty is another important issue to address. According to Galbraith, university faculties have a strong impact on student's teaching practices (1995). "Quality teacher preparation is not the sole responsibility of Colleges of Education; faculty in a variety of departments throughout the university must be involved" (Cooper \& Alvarado, 2006).

According the NAEA, art education faculties are responsible for preparing future art teachers and they should be experts in theories and practice in art education. Also, NAEA added that art education faculty should be active in the art education profession and on other professional committees. Lastly, the NAEA advised for the use of technology in the classroom. They stated as their major art education standard that art education faculty should use technology in their teaching. For example, NAEA considered using computer technology as a research tool and as an instruction tool in the 
art classroom. Mohammed Al-Amri on his study at Sultan Qabos University in Oman suggested "good Art teachers should understand the subjects they teach, as well as related subjects in considerable depth" and added "more attention should be placed on the roles of Art History, Art Criticism, Aesthetics and Visual Cultures in Art and Design, as well as the need to address other trends and issues, such as new technology in making and teaching Art" (2010, p. 2).

One of the responsibilities of the art education faculty is student teaching preparation (Milbrandt, 2006). According to Darweesh, "The lack of qualified instructors who are capable to educate the pre-service teachers" is one of the major problems that affect the teacher preparation program (2010, p. 14). Harrell stated in her study that a teacher's ability to apply the knowledge and skills in art education programs is influenced not only by what is taught, but also by who teaches (2007). Good qualified instructors are an important factor on the preparation of art education students.

\section{Teacher preparation programs and field experience courses}

Third are the teacher preparation programs. Review and research found that teacher preparation programs are different internationally. For example, in the USA, there are different kinds of teacher education programs, and there are many art education programs, and they offer different certificates. Therefore, teachers are labeled differently, such as teachers who entered teaching without prior preparation (or called emergency credentialed), or through transcript review, whereas in my country of Kuwait, there is only one program for teacher preparation that offers a BA in art education. Therefore, all Kuwaiti citizens who are planning to be art teachers graduate from the College of Basic 
Education. Even though the programs vary, they all have one goal: to have a better preparation program. Even though the art teacher programs are diverse, they all have the same components (Galbraith, 1997).

An earlier study by Darling-Hammond found that well prepared teachers are related to their education preparation programs. The study concluded that the examination of teacher education program outcomes is one strategy that may help us to understand features of successful teacher education programs (2000). According to the NAEA, art teacher preparation programs should focus on the contents of visual arts and theory and practice in art education involving traditional and contemporary studio approaches.

According to Day (as cited in Harrell, 2007), even though art education programs exist, many art teachers suffer from a lack of good quality experiences to be well prepared to teach. When beginning teachers fail, we have to investigate the preparation program they graduated from and make sure that their preparation program was providing all they need to be well prepared in their jobs (Harrell, 2007). Cooper and Alvarado stated in their recent study "although most pre-service teachers describe their practicum experiences as the most valuable component of their teacher preparation programs, many practicum experiences are narrowly focused and disconnected from students' previous coursework" (2006).

Another influencing factor is the evaluation of the field experience courses (Cramer, 2008). The experience that pre-service teachers will have during their student teaching courses will strengthen their beliefs and values about schools and teaching (Arnold, 1976; Al-Sayegh, 1998; Harrell, 2007; Cramer, 2008; Grieco, 2011). Indeed 
"clinical experiences are most effective when they are carefully planned, interwoven with coursework, undertaken with highly effective classroom teachers, and carefully supervised" (Cooper \& Alvarado, 2006). A previous case study by Darling-Hammond and MacDonald indicated that field experience courses and pre-service programs should take from 12 to 24 months to complete, depending on how students organize their course taking. The study concluded that every program should includes a full academic year of student teaching under close supervision from university supervisors who also work as course instructors and advisors (Darling-Hammond \& MacDonald, 2000). A survey study found that "teachers who enter through alternative programs that minimize pre-service training and those who enter without prior experience or training feel poorly prepared for many tasks of teaching" (Darling-Hammond; Chung \& Frelow, 2002).

Field experience courses, sometimes called student teaching, clinical field experience, pre-service courses, or observation courses, are part of any art education teacher preparation program (Hovanec, 2011). It is the only course that links school art teacher faculty, university faculty, and art education students. Therefore, it is an important course students take (Arnold, 1976; Dodds, 1985). This experience is an opportunity for student teachers to gain first-hand knowledge of students and school/classroom procedures (Harrell, 2007). It is the only course where students are able to be in real classrooms.

Therefore, art education students will be able to have the experience as art teachers and to experience what real art teachers do and what responsibilities and obstacles teachers may face (Lim, 2008). Studies of in-service teachers indicated that their field experience courses were the most important part of their preparation for the 
classroom (Susi, 1992; Hovanec, 2011). "What the pre-service teacher sees and experiences in the student teaching practicum will either reinforce or restructure their beliefs, values and attitudes concerning schools and teaching" (Harrell. 2007, p. 13). Unlikely, some programs do not offer the field experiences courses or limit them for a few hours only. An article summarized ten studies that are interested in the importance of the field experiences courses for teacher preparation. As stated in the article, "several studies found that field experiences were often disconnected from other components of teacher preparation, and prospective teachers had difficulty applying what they had learned in those other components when they entered their practice" (Wilson, Floden, Robert \& Ferrini-Mundy, 2001).

\section{Description of Art Education Program in Kuwait}

For the purpose of this study, the data collected from the CBE art education department included the program of study, class descriptions, number of faculty teaching art education coursework, mission goals, length of the program, length of the training courses (field experience courses), amount of coursework required for art including art production, art history, art criticism, aesthetics, art education and general education.

\section{The CBE Program of Study}

Student is required to complete 130 credits in art education. These required credit hours are distributed as follows:

- 30 credits for general education courses and elective courses,

- 69 credits for major requirement courses (Studio Art, Art Production, 


\section{Aesthetics and Art Criticism)}

- 11 credits for field training courses (9 credits for school field-training, 2 credits for a seminar course),

- 20 credits for minor courses in Interior Design (Appendix N).

\section{Pre-service and in-service art teachers}

As stated in Harrell's study, Kowalchuk, an associate professor of visual art education at the university of Kansas, suggested three aspects that affected the quality of pre-service and in-service art teachers. These three aspects were used to describe the perceptions of the pre-service and in-service art teachers toward their preparations. The first aspect is "the ecological interpretation of learning to teach. It examines how environment and life experiences contribute to the teacher's decisions and how a student's personal history and prior beliefs affect his or her learning and teaching practices" (Harrell, 2007, p. 15). For example, if a student of art education decided and chooses to be art teacher or to be an educator it is related to his or her experience in school. The second aspect is the technical-developmental perspective. It "looks at the ways that teachers acquire skills" (Harrell, 2007, p. 15). The skills are gained from either the training in the preparation program or from a personal experience in art. The last aspect is the subject matter orientation. It "looks at the ways that teachers make connections between discipline content knowledge and pedagogy knowledge" (Harrell, 2007, p. 15). This aspect depends on how successful art teacher are to connect what they learned in college and apply it to their teaching practicum.

Pre-service art teachers have framed their beliefs toward the teaching experience 
through their long-term experience at their schools. According to Harrell, "the beliefs and attitudes formed by these experiences become a filter for accepting and assimilating or rejecting what is presented in coursework and clinical experiences" (2007, p. 16).

\section{Summary}

According to the findings of the literature review, there are some important concerns on teacher preparation. Many experts in the field around the world are asking an important question: what do new teachers need to know and be able to do? (The National Academy of Education, National Board for Professional Teaching Standard).

The review of the literature concluded that teacher preparation programs including the art teacher preparation programs internationally affect the quality of art programs and the quality of art teachers. Field experience courses and teacher preparation programs, and the role of the university faculty are the main important elements to have a quality of art programs and the quality of art teachers.

\section{Teachers' Problems and Concerns}

How well-prepared teachers feel when they enter teaching is correlated with their sense of teaching efficacy, their sense of responsibility for student learning, and their plans to remain in teaching (Darling-Hammond; Chung \& Frelow, 2002).

\section{Well-prepared teachers are more likely to remain in teaching}

Harrell stated in her study that art teacher educators should test, question, and evaluate to improve preparation programs. She continued stating that better-prepared art 
teachers are better prepared for the challenges they will face in schools today (2007). Around 50 percent of beginning teachers leave teaching within their first five years because they feel not well prepared for real teaching jobs (Darling-Hammond \& Cobb, 1995). According to the U.S. Department of Education, about $25 \%$ of beginning teachers leave their jobs within their first three years (2007).

A recent study stated that "somewhere between 30 and 50 percent of new teachers in the United States and in the United Kingdom leave teaching within the first five years" (Cooper \& Alvardo, 2006). Within the same study, the researchers also indicated some important data regarding the turnover that accrued among the new teachers internationally. For example, "in Germany (less than 5 percent) of the new teachers leave teaching within their first five years, whereas in France and Portugal were (insignificant). In Asia such as Hong Kong, (less than 10 percent), and in Australia (18 percent for female teachers in the age group 25-29 years of age) of the new teachers leaves teaching within their first five years" (2006). As the finding of the study shows, new teachers are struggling during their first five years and as a result some leave their jobs.

A survey study found that "teachers of low-performing students are more likely to leave their current schools during their first two years of teaching" (Boyd; Grossman; Lankford; Loeb \& Wyckoff, 2009). Other researchers in the field also found that teachers who are less effective transfer or leave teaching (Goldharper, 2007).

On the other hand, teachers who are well-prepared for teaching are more likely to stay in service (Darling-Hammond, Chung \& Frelow, 2002). In a recent study, Shen studied 1,702 teachers who had graduated from college within five years. Shen found that 
$34 \%$ of these teachers had left teaching. These $34 \%$ of teachers have no training. On the other hand, teachers who had training were staying in teaching (2003).

Another survey by Darling-Hammond and others in 1998 asked 3000 beginning teachers in New York City to describe their beliefs and perceptions of their preparation for teaching and their plans to remain in teaching. The findings indicate that teachers who were well prepared in their teacher preparation programs are likely more confident and are planning to remain in teaching, while those who do not feel well-prepared are struggling and thinking of leaving teaching (2002).

The survey study found that "teachers who felt poorly prepared were much less likely to say they would pick the same route into teaching again" whereas "Teachers' sense of preparedness and sense of self-efficacy seem related to their feelings about teaching and their plans to stay in the profession" (Darling-Hammond, Chung, \& Frelow, 2002). More researchers in the field also found that teachers, who were not wellprepared, were struggling and have difficulties in the classroom and that they tend to leave teaching. On the other hand, teachers who were well-prepared performed better in their classrooms and were likely to remain in service (Darling-Hammond, 1992; Grossman, 1989; Jelmberg, 1996; National Center for Research on Teacher Learning, 1992).

\section{Good quality teacher preparation helps develop essential knowledge and teaching} skills

In Preparing Teachers for a Changing World, Darling-Hammond and Bransford (2005) identified what teachers should learn and be able to do. Important issues they 
discussed were teacher knowledge and teaching skills. They stated, "Teacher knowledge matters are an important reason to treat teaching as a profession" (Darling-Hammond \& Bransford, 2005, p.15). Knowing the subject matter and having deep knowledge about it is the way to effective teachers and quality teaching (Ortiz, 2008).

In a recent report, Executive Summary: Teacher Preparation Research: Current Knowledge, Gaps, and Recommendations, the authors concluded that there is a positive connection between teachers' preparation in subject matter and their performance in the classroom (2001). Darling-Hammond and Bransford also labeled another key for effective teachers. They found that those who are able to recognize diverse learners and have an understanding of how people learn are effective teachers (2005).

Darling-Hammond and Bransford (2005) stated that "teachers need to be prepared for learning differences and disabilities that are prevalent" (p.36). This finding summarizes what researchers say about the issues and concerns in teacher preparation and knowledge. There are many essential factors that build effective teacher knowledge such as subject matter preparation and teaching diverse learners.

\section{Well-prepared teachers produce higher student achievement}

Researchers have found relationships between teachers' preparation and its effectiveness with students (Darling-Hammond, 2000; Wenglinsky, 2000; DarlingHammond, Chung \& Frelow, 2002). Cooper and Alvarado found that “[w]hen students have as few as two inferior teachers in a row, they almost never catch up academically with their peers" (Cooper \& Alvarado, 2006). Well-prepared teachers will have a positive impact on students' learning. Goldhaber studied over 700,000 student test scores. He 
found that there is a strong relationship between a student's score and teacher education (Goldhaber, 2006). Cooper and Alvarado stated that "[i]f the teacher is consistently successful in helping students to achieve at or above expected levels of academic performance, then he or she can be considered effective and of high quality" (2006).

In the book Powerful Teacher Education: Lessons from Exemplary Programs, Darling-Hammond (2006) investigated many studies and also found that the relationship between students' scores and teacher education is strong. In contrast, if teachers are unprepared or less prepared, their students will be the victims and will not get good education. A survey study found that "[t]eachers who felt better prepared believe they could reach all of their students, handle problems in the classroom, teach all students to high levels, and make a difference in the lives of their students. Those who felt underprepared, feel uncertain about how to teach some of their students" (DarlingHammond, Chung, \& Frelow, 2002).

Darling-Hammond and other researchers suggested that a strong teacher preparation program requires more subject matter preparation, more intensive coursework on content pedagogy and strategies for meeting the needs of diverse learners, and more systematic and connected clinical experiences (Al-Sayegh, 1998; Darling-Hammond, Chung, \& Frelow, 2002), and "knowing appropriate teaching strategies, using time effectively, and having sufficient materials" (Harrell, 2007, p.16). Indeed Cooper and Alvarado argued that "what seem to be needed are not necessarily more content preparation but rather having sufficient knowledge of content to teach it well" (2006). Besides, "some teacher training programs place greater emphasis on subject-matter knowledge than pedagogical knowledge" (Harrell, 2007, p.17). 
According to a study, "[s]ome universities have developed 5-year models that include a disciplinary major and intensive training for teaching, including a yearlong student teaching experience, often in a professional development school" (Darling-Hammond, Chung, \& Frelow, 2002). Other researchers concluded that the more these factors are in the program the more well-prepared the teachers feel and the more teachers will remain teaching (Al-Ahmad, 1980; Andrew, 1990; Andrew \& Schwab, 1995; Baker, 1993; Darling-Hammond, Chung, \& Frelow, 2002).

\section{Conclusion}

The literature review of both general teacher education and art education indicates that to have a high-quality teacher preparation program, the following factors should be considered: (1) how well the pre-service art teachers are prepared, (2) the role of the university faculty, and (3) field experience courses and teacher preparation programs.

Pre-service teachers who had high-quality preparation will have an effective beginning to their teaching and will mostly remain in teaching, and will have a better impact on students' learning and achievements. 


\title{
CHAPTER 3
}

\section{METHODOLOGY}

\author{
Introduction
}

Researchers in Kuwait have established studies and encouraged colleagues to do more research on the evaluation of teacher preparation programs. In recent years, studies evaluating the different teacher preparation programs in Kuwait have been increasing. Yet, not many studies have focused on the evaluation of the art education teacher program. This study interested on the perceptions of pre-service, beginners, and advanced art teachers in Kuwait toward the effectiveness of their teacher preparation program.

In 2001, Al-Najar conducted a research study titled The First and Second Year Elementary Art Education Kuwaiti Teacher's Perception of Their Professional Preparation. The study used a survey questionnaire measurement for only 103 elementary art teachers. The purpose of his study was to examine beginning elementary art teachers' evaluation of the efficacy of their art teacher preparation program at the College of Basic Education (CBE) in Kuwait.

Al-Najar evaluated the CBE art education program through first- and second-year art teachers' perceptions about their preparation in the three areas: content knowledge, curriculum and assessment. As recommended by Al-Najar, the CBE should strengthen the three areas with more practical experience (2001). The study explored how beginning art teachers were well prepared to teach based on three areas in art education: content 
knowledge, curriculum, and assessment. The result of the study found that the first- and second-year art teachers felt well prepared and successful in all the three areas (content knowledge, curriculum, and assessment) (Al-Najar, 2001).

Since there is only one program for preparing art teachers in Kuwait, this study would add more knowledge to the continuous evaluation process, and would add more evaluation and knowledge to CBE art teacher program in Kuwait.

The focus of this study was on recent changes in art teacher education in Kuwait. A different process of evaluation and different contents were used in this study to add more knowledge to the evaluation. The purpose of this research study was to view, examine, and investigate the perceptions of pre-service, beginner, and advanced art teachers about the effectiveness of the teacher education program in the State of Kuwait, field experience-training course in the CBE art teachers program, and the influence of the university faculty and the supervisor to the pre-service art teachers, and to provide comparison between the three groups. The results and findings of this study would be used as a foundation base to offer suggestions for program improvement and the design of local curricular guidelines for the future of the art teacher programs.

\section{The Research Question}

How do pre-service, beginner, and advanced art teachers in Kuwait describe and evaluate their teacher preparation program?

The supporting questions:

1. What are the perceptions of pre-service, beginner, and advanced art teachers in Kuwait 
regarding the theoretical and practical training they received in their teacher education programs?

2. What are the pre-service, beginner, and advanced art teachers in Kuwait feeling regarding how well they think their education prepared them for their current positions?

3. What are the pre-service, beginner, and advanced art teachers in Kuwait feeling regarding the effectiveness of their field experience courses and how it prepared them for their teaching practice during their first years?

4. What are the perceptions of pre-service, beginner, and advanced art teachers in Kuwait regarding what beginning art teachers should know and be able to do and how well they thought their education prepared them for their current position?

5. What are the pre-service, beginners, and advanced art teachers in Kuwait feeling towards the most influencing person during their teacher training?

The first question focused on the perceptions of pre-service, beginner, and advanced art teachers in Kuwait regarding what they learned and received in their teacher education program. The second question focused on the pre-service, beginner, and advanced art teachers feeling regarding what they learned and received in their teacher education program. The third question focused on the pre-service, beginner, and advanced art teachers feeling regarding the effectiveness of their field experience courses and how it prepared them for their teaching practice during their first years. The fourth question focused on the perceptions of pre-service, beginner, and advanced art teachers in Kuwait regarding their preparation to understand and teach art. The fifth question focused on the pre-service, beginner, and advanced art teachers feeling towards the most 
influencing person during their teacher training.

Here are the sequences of the research:

1. Reviewed the literature to determine the scope of the research and to define appropriate questions.

2. Developed a survey based on the review of literature, Kuwait culture, and based of the certification of the $\mathrm{CBE}$ at the state of Kuwait to draw out and explore beginning art teachers' perceptions of their preparedness to teach art.

3. Evaluated and compared the data thematically in terms of the questions asked and the themes that emerge.

4. Drew conclusions from the data and make recommendations for art teacher preparation program at CBE in the State of Kuwait.

\section{Overview of Study}

This study explored the perceptions of pre-service, beginning, and advanced art teachers in Kuwait regarding their teacher training programs and their teaching practices in order to determine the effectiveness of the existing programs in Kuwait, and to make suggestions for improvements. The literature review investigated the preparations and the experiences of pre-service, beginner, and advanced teachers. The investigation revealed the factors that influence the content, the experiences of teaching, and their ability to process and use what is taught during their preparation and the experiences of practicing their teaching. 
The study used a quantitative survey to measure the perceptions of art teachers about their preparation to teach art (Milbrandt, 2006) and whether what they learned during their college and training program met their need in their current teaching jobs.

The survey allowed the possibility of asking large amount of questions in a short period of time. In addition, the survey allowed covering a large number of participants that are intended to include in the study. Also, the survey allowed collecting a wide range of information such as, demographic information, perceptions, past experience, and opinions.

The reason this study chose the survey questionnaire method is that it needed to keep the analysis focused. This made the analysis one dimensional, which is the quantitative. There are a number of reasons why this study chose to utilize a single dimension of analysis, namely the quantitative one. First, it facilitated the analysis process. Second, the results were shared with my colleagues in order to use it as a basis for further research and policy change.

The data was generated through quantitative survey questionnaires (Morse, 1991). According to Babbie (1995), the best method to collect data for describing and measuring the perceptions of a huge population is the survey research method. To assure and establish internal reliability and validity, the data should gather through different methods (Zimmerman, 1997). This study also used document analysis of mission statements from both the College of Basic Education in Art Education department and the Ministry of Education in Art Education. These documents were freely available online. 


\section{Research Strategy and Rationale}

Researchers used mixed methods design, which combined quantitative and qualitative research techniques. According to Bowen, "There has been an increase in the number of research reports and journal articles that mention document analysis as part of the methodology" (Bowen, 2009, p.27). Bowen also described the benefits of using the document analysis. As stated in Bowen's article, “documents of all types can help the researcher uncover meaning, develop understanding, and discover insights relevant to the research problem" (Bowen, 2009. P. 29).

The study included a qualitative document analysis and a quantitative survey of preservice, beginner, and advance art teachers, in light of a description of the art education program in the college of Basic Education from which the teachers graduated (Appendix $B \& C)$.

Human Subjects Review - IRB

Prior to engaging in the data collection, this study obtained an approval from the Institutional Review Board (IRB) for the protection of the human subjects at the West Virginia University (WVU) (Appendix A). Also this study obtained permission letters from the Kuwaiti educational institutions: Kuwait University (KU), the College of Basic Education (CBE), and the Kuwaiti Ministry of Education (MOE) (Appendix E \& G).

\section{Sources of Data}

The sources of data for this study were: (1) pre-service Kuwaiti art teachers at the College of Basic Education (CBE), (2) in-service art teachers at the Ministry of 
Education (MOE), and (3) document analysis from both the CBE and MOE.

\section{Population}

A sample of the Kuwait public schools was found through a list of all public schools at the Ministry of Education in Kuwait for the 2012- 2013 school year. The list was obtained from the Ministry of Education MOE in Kuwait in September of 2013. Included were school names and locations, numbers of male schools and female schools in each district.

MOE have five different regions: Al-Ahmadi, Al-Aasma, Hawalli, Al-Farwania, Al-Jahra, and Mubarak Al-Kber. This study selected art teachers from both the Al-Aasma and Hawalli regions as part of the whole population. Al-Aasma has 44 elementary schools ( 22 boys schools and 22 girls schools), 32 middle schools ( 15 boys schools and 17 girls schools), and 26 high schools (13 boys schools and 13 girls schools.) Whereas Hawalli has 36 elementary schools (19 boys schools and 17 girls schools), 31 middle schools ( 15 boys schools and 16 girls schools), and 22 high schools (11 boys schools and 10 girls schools) (MOE, statistic 2012-201, Appendix P, O).

A sample of participants was found through a list of all art teachers who worked in the public schools at the Ministry of Education in Kuwait for the 2012- 2013 school year. The list was obtained from the Ministry of Education in Kuwait in September of 2013. Included were a number of male and female art teacher in every districts.

The selection of schools for this study used the random listing methods that chose every third school from the list. The sample was randomly selected from the population of art teachers who work as an art teacher in public schools at either Al-Aasma or 
Hawalli regions in Kuwait. According to the MOE, Al-Aasma has 224 elementary art teachers (21 male and 203 female), 133 middle school art teachers (85 male and 75 female), and 72 high school art teachers (28 male and 44 female). Whereas Hawalli has 222 elementary art teachers (113 male and 109 female), 128 middle school art teachers (48 male and 80 female), and 57 high school art teachers (26 male and 31 female). The total population of art teachers at both al Aasma and Hawalli are 836. (MOE, statistic 2012-2013, Appendix P, O).

\section{Participants}

The sample of this study consisted of Kuwaiti art education students and Kuwaiti art teachers. The sample of this study was selected from the total population of art teachers and students from: (1) pre-service Kuwaiti art teachers who have completed their classroom observation at the end of the fourth year at the College of Basic Education (CBE). The estimated population of the pre-service art teachers in the College of Basic Education (CBE) during the fall 2013 that were participate in this study was 83 with 21 male and 62 female. This population was selected because they are the only national representatives of the pre service art educators in the State of Kuwait. From the whole population of the 83 art students, 80 surveys were delivered to randomly male and female art teachers. A sample of 69 participants were completed the survey with a margin of error $5 \%$ and confidence level $95 \%$. The response rate for this study was $86.25 \%$.

(2) In-service art teachers at the Ministry of Education (MOE). The estimated population of the in-service art teachers in the Ministry of Education (MOE) during the 
fall 2013 that were participate in this study was 836. From the whole population of the 836 of art teachers, 300 surveys were delivered to randomly male and female art teachers. A sample of 264 participants were completed the survey with a margin of error $5 \%$ and confidence level $95 \%$. The response rate for this study was $88 \%$. The in-service art teachers have two groups. First, beginning art education teachers who are teaching in the first of their second year at the Ministry of Education in Kuwait $(n=124)$. Second, advanced art teachers, who are ready to teach in the beginning of their fourth year at the Ministry of Education in Kuwait ( $\mathrm{n}=140)$.

The reason this study focused on only the selected groups was because it do not want large gaps between art teachers who just graduated and art teachers who have more teaching experience. This study focused on the existing program in the College of Basic Education and did not evaluate an old or none existing program. Finally, more experienced art teachers may not remember their program.

\section{Procedure}

The sample selected and group format

Surveys were given to the three groups and they were compared (Murphy, P. Delli, L. M., and Edwards, 2004). The data collected during the first month of the academic school year during the fall semester in October 2013. A total of $(n=333)$ of pre-service male and female Kuwaiti art teachers and in-service male and female Kuwaiti art teachers participated in this study.

\section{Setting}


The survey was conducted through two places. The first place was in classes at the Department of Art Education in the CBE. The researcher and the art instructors who were teaching these art classes were presented during the survey data collection. The second place was at schools in the Ministry of Education MOE. The survey delivered to each school by either by hand or fax (Appendix B \& C). This study cooperated with the head of art education at the Ministry of Education in Kuwait to reach the participants and to schedule a meeting to hand out the survey to the participants. The meeting was in school during the regular hours, and the participants were given the option to not participate or not give personal information.

Participation in the questionnaire was voluntary, and all subjects had the option to choose whether to complete and return the questionnaire. Each participant needed 10 to 15 minutes to complete the survey questionnaire. A cover letter was provided with each survey to explain the importance of the study, the purpose of the study, the amount of time that is needed to complete the questionnaire, a consent form, and contact information for the investigator and the research advisor (names, emails, addresses, and office phone numbers) (Appendix D). The questionnaire was distributed and collected by the researcher. The alpha was a standard 0.05 . This study achieved a response rate of $89 \%$.

Instrument

This study used a quantitative survey questionnaire and qualitative document analysis. The survey questionnaire was used to measure the perceptions of art teachers 
about their preparation to teach art. The measurements were the survey questionnaire and the independent variable was the questions.

The survey questionnaire was adapted and modified from Harrell. The survey was designed to measure the perceptions of the preparation to teach art among art teachers in Florida. Content validity was good because this survey included some of the questions the study intended to cover. The survey questionnaire was also modified to add some survey questions to be suitable to Kuwait.

A survey was adapted from Harrell studies, and was modified to be based on the issues that related to teacher preparation and training courses as discussed in the literature review. (Blackman, 1977; Chapman, 1979; Darling-Hammond, Chung, \& Frelow, 2002; Jeffers, 1996; Harrell, 2007; Darweesh, 2010; Bufarsan, 2000) and based on the culture, tradition, religion, and CBE requirement to obtain a certificate in teaching art in the state of Kuwait. The survey was pre-tested with a convenience sample of two participants and then a convenience sample of ten participants. As Stated in Harrell study, Fowler recommended "the pretest survey included a set of questions specifically about the questionnaire itself, regarding whether the questions were confusing or difficult to answer" (Harrell, 2007, p. 27). This method is used to ensure that the survey questions were clearly understood and the participants are able to answer every question in the questionnaire, and the survey questions would measured what they were intended to measure.

The survey was described in a following segment. The survey contained items asking for demographic and background information, perceptions of an evaluation of how well prepared they felt they were in specific areas of teaching, and their teacher training 
in relation to their teaching experiences. A self-administered questionnaire was used for this study. The mode of the questionnaire used in this study was the type that a respondent completes on his/her own on paper.

The purpose of the survey was to investigate how pre-service, beginner, and advanced teachers feel about the effectiveness of the teacher education program in preparing them for their occupations and to make planned comparisons. The goal was to describe, explore, and explain the particular attributes of a large population (Chapman, 1979; Babbie, 1995; Jaeger, 1997; Sonquist and Dunkelberg, 1977; Burton, 2001; Creswell and Plano Clark, 2007), how well this course prepared them, and how their training has affected their teaching practice. Survey research is "an appropriate methodology for gathering data concerning the attitudes and perceptions of a large group of teachers and for evaluating and developing art programs" (Harrell, 2007, p. 43).

The second part of the instrument was the qualitative document analysis. The document analyses, which were used in this study, were taken from both the College of Basic Education in Art Education department and the Ministry of Education in Art Education. These documents were freely available online. Bowen stated in her study “documents provide supplementary research data base. Information and insights derived from document can be valuable additions to a knowledge base" (Bowen, 2009, p. 30). There are some advantages to use document analysis in a research that were stated in Bowen article such as:

$\circ$ Efficient method: document analysis is less time-consuming.

- Availability: Many document are in the public domain, especially since the event of the Internet and are obtain without the authors' permission. 
- Cost-effectiveness: document analysis is less costly than other research methods (Bowen, 2009, p. 31).

This study used and examined the documents from both art education programs at the MOE, and the art education department at $\mathrm{CBE}$ in order to gain benefits to the research and to help the researcher understand the meaning and goals of the art education in Kuwait.

\section{Description of the survey}

The survey in this study included three parts to gather different types of information. The first part gathered demographic information such as gender, age, level of teaching, years of teaching experience, and institution attended to set a context for evaluating information in the other parts of the survey (Darling-Hammond, Chung, \& Frelow, 2002; Jeffers, 1996, Harrell, 2007). The second part asked the participants to rate how well prepared they felt they were when they first entered the teaching profession. As stated in Harrell study, this section used closed-ended questions to increase consistency of response across respondents and to allow for ranking of how well prepared participants felt they were on each of the skills listed (Darling-Hammond, Chung, \& Frelow, 2002; Jeffers, 1996, Fraenkel \& Wallen, 2003, Harrell, 2007). The format used in this study was a Likert-like scale whether that they felt very well prepared, more than adequately prepared, adequately prepared, less than adequately prepared, or poorly prepared. Harrell suggests, "These dimensions range from teaching studio skills in different media to classroom management and meeting the needs of diverse students" (Harrell, 2007, p. 30). The third part asked the participants to rate their responses through a five point Likert 
scale $(\mathrm{SA}=$ strongly agree, $\mathrm{A}=$ agree, $\mathrm{D}=$ disagree, $\mathrm{SD}=$ strongly disagree and $\mathrm{U}=$ undecided or don't know $=\mathrm{DK}$ ). The rating scale was designed to measure the Kuwaiti pre-service and in-service art teachers' feeling toward the effectiveness of the art teacher preparation. The questions matched the response format and the response categories labeled appropriately. The questions were designed to explore what participants have learned in relation to what they now feel they need to know and whether or not they felt well prepared during their first years of teaching.

According to Seidman (as cited in Harrell, 2007) the selection of participants was a purposeful maximum variation sampling. "This method of sampling allowed for the maximum range of people and sites to be selected from the larger population" (Harrell, 2007).

Permission forms were approved from the IRB in the U.S and Kuwait (Appendix A, E, and F). Also, permission forms were approved from the art education department at the Ministry of Education in Kuwait and from the CBE (Appendix G, H). The participants' selection was through convenience random sampling. Kvale and Brinkmann also suggest a convenience sampling (Kvale \& Brinkman, 2009). It is a convenience sampling because this study wanted to select participants based on the availability and convenience, and it was also a purposive sampling because the participants were only those who met the study. The surveys were translated into Arabic because the first language in Kuwait is Arabic (Appendix I \& J). Both English and Arabic versions of the survey questionnaire were available for the participants to chose from based on their preference (Appendix M). 


\section{Data Collection}

Before collecting the data, permissions from both the College of Basic Education and the Ministry of Education were approved to conduct the study (See Appendix A), and approval from the Institutional Review Board (IRB) (See Appendix E, F, G, H).

The survey questionnaire included: demographic information background and characteristics such as age, gender, level of teaching and years of experience (DarlingHammond, Chung, \& Frelow, 2002), perceptions and feeling of their teacher preparation program. Survey research methodology is the best way for gathering data concerning the perceptions of a large group of teachers and for evaluating and developing art programs (Harrell, 2007; Bullock and Galbraith, 1992).

\section{Design}

This was a cross-sectional study that has three groups testing in the same time period. The first group was art teacher students in their last year in college and in the field experience courses. The second group was art teachers who were in service in their second year. The third group was art teachers who were in their fourth year of service in teaching. Static-group comparison design was used because the study had already three different non-randomly formed groups,

$\mathrm{X} 10$

$\mathrm{X} 20$

X3 0 
The research method was a descriptive method that used quantitative and qualitative approach.

\section{Validity}

The instrument that'll be used to measure perceptions is a locally developed instrument with no solid validity, as it has not been replicated. This study aims at improving the validity of the instrument. However, to increase validity prior to use in this study, the existing instrument will be given to two judges to check for face validity. The judges should ideally be professionals in the field of education or educational psychology, as well as related disciplines. The ratings from these two external judges will be examined for validity.

\section{Reliability}

To ensure reliability of the instrument, this study utilized a test-retest technique. The instrument (without the demographic data part) were given to a small subset of the larger research participant number participants again after two weeks to check for reliability

\section{Data Analysis}

Quantitative Data Analysis Process

This study used the Statistical Package for the Social Survey (SPSS) 16.0 computer software to analyze the data. Descriptive quantitative analysis was used to interpret the survey data. For analyzing the data, this study used a descriptive data 
analysis. The data was presented in a descriptive manner with frequency distributions, percentages, and means.

Total size of population and the percentage of the returns surveys were reported. The demographic responses were categorized through descriptors and reported as percentages. Survey respondents were coded, and comparisons between responses also were reported. The perceptions responses were analysis through mean rating. Those rating "were calculated in order to rank teaching competencies from those teachers who felt most prepared to perform to those who felt less prepared to perform" (Harrell, 2007, p. 33). A comparison between the mean ratings of the survey responses were reported and analyzed.

The responses were analysis through post-coding. "With regards to the coding process, each category (answer) for each item/concept in the questionnaire was assigned with a numerical code. Then, these items/concepts were computed to set a total score" (Darweesh, 2010, p. 65). The data compared the answers statistically between the three groups thorough coding the answers by themes and compared them. The average of the rating of each group and the percentages of the participants' responded were used in this study. "The research findings were reported as percentages. Those percentages enabled the researcher to understand and describe the data" (Darweesh, 2010, p. 65). Comparisons between individual responses to the survey questions were conducted to determine the differences among the three groups.

After all the data have been collected, and the analysis has been completed, the researcher wrote an extensive summary of the all findings for this study. 


\section{Qualitative Content Data Analysis Process}

Bowen stated in her article "document analysis involves skimming, reading, and interpretation" (Bowen, 2009, p.32). Bowen stated in her article "document analysis involves skimming, reading, and interpretation" (Bowen, 2009, p.32). According to Hsieh, content analysis is a widely used in qualitative research (Hsieh, 2005). Hsied added, Content analysis allows interpreting meaning from the content of text. This study used the summative content analysis because it involves comparisons between the content followed by the interpretation of the underlying context. An examination of the Web pages of both the MOE and CBE mission goals was conducted to gather information regarding the similarity and the differences between both general mission goals.

A chart describing which survey questions answer which research questions:

Main research question:

How do pre-service, beginner, and advanced art teachers in Kuwait describe and evaluate their teacher preparation program?

The supporting questions:

\begin{tabular}{|l|l|l|}
\hline$\#$ & Research supporting question & $\begin{array}{l}\text { Survey research questions } \\
\text { that answer the research } \\
\text { question }\end{array}$ \\
\hline 1 & $\begin{array}{l}\text { What are the perceptions of pre-service, beginner, and } \\
\text { advanced art teachers in Kuwait regarding the } \\
\text { theoretical and practical training they received in their } \\
\text { teacher education programs? }\end{array}$ & $\begin{array}{l}\text { Survey (Pre-service) } \\
\text { questions number: } \\
15,16,17,18,19,21 \\
\text { Survey (In-service) } \\
\text { questions number: } \\
18,19,20,21,22,24\end{array}$ \\
\hline 2 & $\begin{array}{l}\text { What are the of pre-service, beginner, and advanced } \\
\text { art teachers in Kuwait feeling regarding how well they } \\
\text { think their education prepared them for their current } \\
\text { positions? }\end{array}$ & $\begin{array}{l}\text { Survey (Pre-service) } \\
\text { questions number: } \\
\text { 22, 26, 31, 32, 35 } \\
\text { Survey (In-service) } \\
\text { questions number: }\end{array}$ \\
\hline
\end{tabular}




\begin{tabular}{|c|c|c|}
\hline & & $25,29,34,35,38$ \\
\hline 3 & $\begin{array}{l}\text { What are the pre-service, beginner, and advanced art } \\
\text { teachers in Kuwait feeling regarding the effectiveness } \\
\text { of their field experience courses and how it prepared } \\
\text { them for their teaching practice during their first } \\
\text { years? }\end{array}$ & $\begin{array}{l}\text { Survey (Pre-service) } \\
\text { questions number: } \\
25,30,33,34 \\
\text { Survey (In-service) } \\
\text { questions number: } \\
28,33,36,37\end{array}$ \\
\hline 4 & $\begin{array}{l}\text { What are the perceptions of pre-service, beginner, and } \\
\text { advanced art teachers in Kuwait regarding what } \\
\text { beginning art teachers should know and be able to do } \\
\text { and how well they thought their education prepared } \\
\text { them for their current position? }\end{array}$ & $\begin{array}{l}\text { Survey (Pre-service) } \\
\text { questions number: } \\
4,5,6,7,8,9,10,11,12 \text {, } \\
13,14,20 \\
\text { Survey (In-service) } \\
\text { questions number: } \\
7,8,9,10,11,12,13,14 \text {, } \\
15,16,17,23\end{array}$ \\
\hline 5 & $\begin{array}{l}\text { What are the pre-service, beginner, and advanced art } \\
\text { teachers in Kuwait feeling towards the most } \\
\text { influencing person during their teacher training? }\end{array}$ & $\begin{array}{l}\text { Survey (Pre-service) } \\
\text { questions number: } \\
23,24,27,28,29 \\
\text { Survey (In-service) } \\
\text { questions number: } \\
26,27,30,31,32 \\
\end{array}$ \\
\hline
\end{tabular}

\section{Time schedule}

The chart below describes the time sequences that used for this study to select, collect, and analysis the data.

\begin{tabular}{|l|l|l|l|l|l|}
\hline & October & November & December & January & February \\
\hline $\begin{array}{l}\text { Select } \\
\text { participants }\end{array}$ & ------------- & & & & \\
\hline $\begin{array}{l}\text { Distribute the } \\
\text { survey }\end{array}$ & - ------------- & & & & \\
\hline Execute study & --------------- & & & & \\
\hline $\begin{array}{l}\text { Collect survey } \\
\text { data }\end{array}$ & ------------ & & & & \\
\hline Analyze data & & ------------- & --------------- & & \\
\hline Write report & & & & ----------- & -------------- \\
\hline
\end{tabular}




\section{Summary}

This chapter described the methodology that been used in this study. It addressed the sources of data for the study, survey questionnaires, document analysis, setting, research design, procedure, data selection, data collection, and qualitative and quantitative data analysis. Research main questions and supporting questions, sequences

of the research, and participants of the study are described and defined. IRB, validity and reliability issues were also addressed.

Scope and limitation of the study

This study examined effectiveness of the existing art education preparation program in Kuwait. Therefore participants who have received their teacher education outside the program were not included in this study. Art teachers whom teaching experience exceeded four years were also excluded from the study. This study focused only on art teacher's perceptions toward their preparations efficiency. 


\section{Chapter Four}

\section{RESULTS}

This chapter presents the results of a study that examined how pre-service, beginning, and advanced art teachers in Kuwait view their teacher preparation program. The data were gathered through a survey questionnaire (Appendix B, C). The survey instrument were adapted and modified from Harrell study (Harrell, 2007). The surveyincluded information regarding how well prepared art teachers feel they were to teach and practice skills, concepts, and duties in art education. Descriptive statistics were generated to summarize the quantitative data. Additionally qualitative content analyses were identified and analyzed using comparative analysis to identify key themes and categories related to the research questions to illustrate the finding.

\section{Part One: Demographic Data of Participants}

A total of 333 pre-service, beginners and advanced art teachers participated in this study. Most of the participants $(\mathrm{N}=324,97.3 \%)$ were Kuwaiti pre-service and in-service art teachers whereas, 9 participants were Non-Kuwaiti (2.7\%). 69 of the participants were pre-service art teachers $(20.7 \%), 124$ of the participants were in-service beginning art teachers $(37.2 \%)$, and 140 of the participants were in-service advanced art teachers $(42.0 \%)$

Table 1. 
Number of participants in the three groups

\begin{tabular}{|l|l|l|}
\hline Respondents & Number & Percentage \\
\hline Pre-service Art Teachers & 69 & $20.7 \%$ \\
\hline In-service Beginner Art Teachers & 124 & $37.2 \%$ \\
\hline In-service Advanced Art Teachers & 140 & $42.0 \%$ \\
\hline
\end{tabular}

Gender of Participants

The first item in the survey asked respondents their gender. The 333 of the respondent were female $65.2 \%(\mathrm{n}=217)$ and a much lower percentage of males reported at $34.8 \%(\mathrm{n}=116)$. Pre-service art teachers reported 21 male and 48 female, whereas inservice beginning art teachers reported 49 male and 75 female, and in-service advanced art teachers reported 46 male and 94 female.

Table 2.

Gender of Participants

\begin{tabular}{|l|l|l|}
\hline Gender & Numbers & Percentage \\
\hline Male & 116 & $34.8 \%$ \\
\hline Female & 217 & $65.2 \%$ \\
\hline Total & 333 & $100.0 \%$ \\
\hline
\end{tabular}

Table 3.

Gender of Participants in Each Group

\begin{tabular}{|l|l|l|}
\hline Respondents & Gender & Total \\
\hline
\end{tabular}




\begin{tabular}{|l|c|c|l|}
\hline & \multicolumn{1}{|l|}{ Male } & Female & \\
\hline Pre-service Art Teachers & 21 & 48 & 69 \\
\hline In-service Beginner Art Teachers & 49 & 75 & 124 \\
\hline In-service Advanced Art Teachers & 46 & 94 & 140 \\
\hline Total & 116 & 217 & 333 \\
\hline
\end{tabular}

Age of Participants

Respondents were asked what their age was based on a scale which included 18$22,23-27,28-32$, and over 33 . The highest percentage was in the range from 23-27 with $36 \%(n=120)$. The second highest was $28-32$ with $26.7 \%(n=89)$ and the third highest was $18-22$ with $21.6 \%(n=72)$. The last group of the 33 and more reported the least participants with $15.6 \%(\mathrm{n}=52)$.

Table 4.

Age of the participants

\begin{tabular}{|l|l|l|}
\hline Age & Numbers & Percentage \\
\hline $18-22$ & 72 & $21.6 \%$ \\
\hline $23-27$ & 120 & $36 \%$ \\
\hline $28-32$ & 89 & $26.7 \%$ \\
\hline $33+$ & 52 & $15.6 \%$ \\
\hline Total & 333 & $100 \%$ \\
\hline
\end{tabular}

\section{Level Teaching}

Respondents were asked what their level they teach right now. The highest percentage was elementary teaching with $41.1 \%(n=137)$. The second highest was 
teaching in middle school with $28.8 \%(\mathrm{n}=96)$ and the third highest was the pre-service art teachers with $20.7 \%(n=69)$. The last group was teaching in high school reported the least participants with $9.3 \%(n=31)$.

Table 5.

Level Teaching

\begin{tabular}{|l|l|l|}
\hline & Frequency & Percentage \\
\hline Elementary & 137 & $41.1 \%$ \\
\hline Middle School & 96 & $28.8 \%$ \\
\hline High School & 31 & $9.3 \%$ \\
\hline Pre-service Art Education Students & 69 & $20.7 \%$ \\
\hline Total & 333 & $100 \%$ \\
\hline
\end{tabular}

Years of Teaching Experience

The participants were asked the number of years they had been teaching art including the current year. The majorities at 24.9\% $(n=83)$ were in their fourth year of teaching experience while $20.7 \%(n=69)$ reported were still in college, and $17.1 \%(n=57)$ reported being in their first years. Two years group $12.9 \%(n=43)$ and more than four years group $12.9 \%(n=43)$ reported same data. Lastly, the three year group reported the least participants as $11.4 \%(\mathrm{n}=38)$.

Table 6.

Number of Years Teaching Art

\begin{tabular}{|l|l|l|}
\hline Number of Years Teaching & Frequency & Percentage \\
\hline
\end{tabular}




\begin{tabular}{|l|l|l|}
\hline Art & & \\
\hline One Year & 57 & $17.1 \%$ \\
\hline Two Years & 43 & $12.9 \%$ \\
\hline Three Years & 38 & $11.4 \%$ \\
\hline Four Years & 83 & $24.9 \%$ \\
\hline More Than Four Years & 43 & $12.9 \%$ \\
\hline $\begin{array}{l}\text { Pre-service Art Education } \\
\text { Students }\end{array}$ & 69 & $20.7 \%$ \\
\hline Total & 333 & $100 \%$ \\
\hline
\end{tabular}

\section{College/ University Attending}

Most of the participants in this survey were graduated from the College of Basic Education in Kuwait $90.1 \%(\mathrm{n}=300)$, whereas $7.5 \%(\mathrm{n}=25)$ were graduated from other institutes. Another 8 (2.4\%) participants reported that they graduated from Kuwait University.

Table 7.

College/ University Attending

\begin{tabular}{|l|l|l|}
\hline & Frequency & Percentage \\
\hline College of Basic Education CBE & 300 & $90.1 \%$ \\
\hline Kuwait University KU & 8 & $2.4 \%$ \\
\hline Others & 25 & $7.5 \%$ \\
\hline Total & 333 & $100 \%$ \\
\hline
\end{tabular}

\section{Part Two: Art Teachers' perceptions of preparedness and Training Experiences}

In part two, respondents were asked to rank their perceptions of their 
preparedness to teach or perform 18 skills required by the College of Basic Education in Kuwait in order to obtain art education certification. They could indicate their preparedness on a five-point scale from very well prepared to poorly prepared. Ranked from lowest to highest means, the lowest mean is the more prepared they feel. Mean scales were 1 - 5 . Mean below 2 on the scale represent very well prepared. Mean range from $2-2.5$ represented more than adequately prepared. Mean range from $2.5-3$ represented adequately prepared. Mean range from $3-3.5$ represented less than adequately prepared. Mean above 3.5 represented poorly prepared.

\section{Pre-service art teacher's perceptions of preparedness}

Pre-service art teachers of CBE felt very well prepared to teach drawing, painting, art history, and maintain control of classroom management (Mean between 1.5 2 on the scale). They were also more than adequately prepared to teach art criticism, maintain control of student behavior, meet the needs of culturally diverse students, teach ceramics, meet the needs of the gifted and talented students, use technology in classroom, teach sculpture, and teach printmaking (Mean between $2-2.5$ on the scale). The respondents felt adequately prepared to teach fiber arts, meet the needs of the handicapped, use a variety of assessments to determine student progress, teach mixed media, teach graphic design, and teach computer applications (Mean between 2.5 - 3 on the scale).

Table 8 .

Pre-service art teachers' perceptions of preparedness 


\begin{tabular}{|l|c|}
\hline How well prepared did you feel to: & Mean \\
\hline Teach drawing & 1.5072 \\
\hline Teach painting & 1.5942 \\
\hline Teach art history & 1.7826 \\
\hline Maintain control of classroom management & 1.8986 \\
\hline Teach art criticism & 2.0000 \\
\hline Maintain control of student behavior & 2.0290 \\
\hline Meet the needs of culturally diverse students & 2.1159 \\
\hline Teach ceramics & 2.1449 \\
\hline Meet the needs of the gifted and talented students & 2.1739 \\
\hline Use technology in classroom & 2.1884 \\
\hline Teach sculpture & 2.2609 \\
\hline Teach printmaking & 2.3913 \\
\hline Teach fiber arts & 2.5507 \\
\hline Meet the needs of the handicapped & 2.5507 \\
\hline Use a variety of assessments to determine student progress & 2.5797 \\
\hline Teach mixed media & 2.6377 \\
\hline Teach graphic design & 2.7246 \\
\hline Teach computer applications & 2.8261 \\
\hline
\end{tabular}

In-service Beginner art teachers' perceptions of preparedness

In-service beginners art teachers at MOE felt more than adequately prepared to teach drawing, painting, art history, maintain control of classroom management, teach art criticism, maintain control of student behavior, and meet the needs of culturally diverse students (Mean between $2-2.5$ on the scale). They were also adequately prepared to teach ceramics and to meet the needs of the gifted and talented students (Mean between 2.5 - 3 on the scale). The respondents felt less than adequately prepared to teach sculpture, use technology in classroom, teach printmaking, teach fiber arts, meet the needs of the handicapped, use a variety of assessments to determine student progress, and teach mixed media (Mean between $3-3.5$ on the scale). The respondents felt poorly prepared to teach graphic design and to teach computer applications (Mean 
between 3.5 - 4 on the scale).

Table 9

In-service Beginner art teachers' perceptions of preparedness

\begin{tabular}{|l|c|}
\hline How well prepared did you feel to: & Mean \\
\hline Teach drawing & 2.1290 \\
\hline Teach painting & 2.1452 \\
\hline Teach art history & 2.1694 \\
\hline Maintain control of classroom management & 2.1855 \\
\hline Teach art criticism & 2.1855 \\
\hline Maintain control of student behavior & 2.3145 \\
\hline Meet the needs of culturally diverse students & 2.5000 \\
\hline Teach ceramics & 2.5403 \\
\hline Meet the needs of the gifted and talented students & 2.7016 \\
\hline Use technology in classroom & 3.2016 \\
\hline Teach sculpture & 3.2339 \\
\hline Teach printmaking & 3.2823 \\
\hline Teach fiber arts & 3.3548 \\
\hline Meet the needs of the handicapped & 3.3952 \\
\hline Use a variety of assessments to determine student progress & 3.4113 \\
\hline Teach mixed media & 3.4839 \\
\hline Teach graphic design & 3.5645 \\
\hline Teach computer applications & 3.7097 \\
\hline
\end{tabular}

In-service Advanced art teachers' perceptions of preparedness

In-service advanced art teachers at MOE felt more than adequately

prepared to teach drawing, painting, art history, maintain control of classroom

management, and to teach art criticism (Mean between $2-2.5$ on the scale). They were also felt adequately prepared to maintain control of student behavior, meet the needs of culturally diverse students, teach ceramics, meet the needs of the gifted and talented students, use technology in classroom, teach sculpture, teach printmaking, teach fiber 
arts, and meet the needs of the handicapped (Mean between 2.5 - 3 on the scale). The respondents felt less than adequately prepared use a variety of assessments to determine student progress, teach mixed media, teach graphic design, and teach computer applications (Mean between $3-3.5$ on the scale).

Table 10

In-service Advanced art teachers' perceptions of preparedness

\begin{tabular}{|l|c|}
\hline How well prepared did you feel to: & Mean \\
\hline Teach drawing & 2.2143 \\
\hline Teach painting & 2.2500 \\
\hline Teach art history & 2.3286 \\
\hline Maintain control of classroom management & 2.4429 \\
\hline Teach art criticism & 2.4571 \\
\hline Maintain control of student behavior & 2.5214 \\
\hline Meet the needs of culturally diverse students & 2.5857 \\
\hline Teach ceramics & 2.6071 \\
\hline Meet the needs of the gifted and talented students & 2.7000 \\
\hline Use technology in classroom & 2.8071 \\
\hline Teach sculpture & 2.9071 \\
\hline Teach printmaking & 2.9286 \\
\hline Teach fiber arts & 2.9571 \\
\hline Meet the needs of the handicapped & 2.9714 \\
\hline Use a variety of assessments to determine student progress & 3.0857 \\
\hline Teach mixed media & 3.1500 \\
\hline Teach graphic design & 3.1643 \\
\hline Teach computer applications & 3.3286 \\
\hline
\end{tabular}

\section{Part Three: Art Teachers' Attitudes and Feelings}

In part three, the last section in the survey questionnaire involved the use of 5point Likert scale (strongly disagree as SD, disagree as D, Don't Know as DK, agree as 
A, strongly agree as SA) to evaluate the Kuwaiti pre-service and in-service art teachers' feelings towards how well they think their education prepared them for their current positions, towards the most influencing person during their teacher training, and regarding the effectiveness of their field experience courses and how it prepared them for their teaching practice during their first years. The survey included fourteen items $(22$, $23,24,25,26,27,28,29,30,31,32,33,34$, and 35) regarding their feelings towards the effectiveness of their preparation program.

Positive and negative opinions and feelings were reported in the results. The first table shows positive opinions and feelings toward the preparedness to teach art in the first year of teaching among pre-service art teachers groups. The majority of pre-service art teachers agreed that they felt well prepared in their first year of their teaching $(44.9 \%, n=$ 31), and the majority of in-service beginner art teachers also agreed that they felt well prepared to teach during their first year of teaching $(32.3 \%, n=40)$, whereas the majority of in-service advanced art teachers reported negative opinions toward the preparedness to teach art in the first year of teaching $(25.7 \%, n=36)$.

Table 11

I feel well prepared to teach art in the first years of teaching

\begin{tabular}{|l|l|l|l|l|l|l|l|l|}
\hline$\#$ & \multicolumn{2}{|l|}{$\begin{array}{l}\text { I feel well prepared to teach art in the first } \\
\text { years of teaching }\end{array}$} & SD & D & DK & A & SA & Total \\
\hline 1 & Pre-Service Art Teachers & $\mathrm{N}$ & 7 & 14 & 5 & 31 & 12 & 69 \\
\cline { 3 - 9 } & & $\%$ & 10.1 & 20.3 & 7.2 & 44.9 & 17.4 & 100 \\
\hline 2 & In-Service Beginner Art Teachers & $\mathrm{N}$ & 27 & 22 & 5 & 40 & 30 & 124 \\
\cline { 3 - 9 } & & $\%$ & 21.8 & 17.7 & 4.0 & 32.3 & 24.2 & 100 \\
\hline 3 & \multirow{2}{*}{ In-Service Advanced Art Teachers } & $\mathrm{N}$ & 30 & 36 & 17 & 35 & 22 & 140 \\
\cline { 3 - 9 } & $\%$ & 21.4 & 25.7 & 21.1 & 25.0 & 15.7 & 100 \\
\hline
\end{tabular}


The next item asked the participants to respond to whether they were able to have contact with other art teachers in either in the same school or in other schools. The majority of respondents in the pre-service art teachers group have positive attitude toward being able to contact with other art teachers in the same school $(33.3 \%, n=23)$, whereas uncertain or don't know opinions and feelings about being able to contact with other art teachers in the other school were reported at $(30.4 \%, n=21)$.

Table 12

I have contact with other art teachers either in the same school or in other schools (Preservice art teachers)

\begin{tabular}{|l|l|l|l|l|l|l|l|l|}
\hline$\#$ & Statement & SD & D & DK & A & SA & Total \\
\hline 1 & $\begin{array}{l}\text { I have contact with other art teachers in } \\
\text { the same school }\end{array}$ & $\mathrm{N}$ & 7 & 8 & 13 & 23 & 18 & 69 \\
\cline { 4 - 10 } & $\%$ & 10.1 & 11.6 & 18.8 & 33.3 & 26.1 & 100 \\
\hline 2 & $\begin{array}{l}\text { I have contact with other art teachers in } \\
\text { other schools }\end{array}$ & $\mathrm{N}$ & 9 & 10 & 21 & 18 & 11 & 69 \\
\cline { 4 - 10 } & $\%$ & 13.0 & 14.5 & 30.4 & 26.1 & 15.9 & 100 \\
\hline
\end{tabular}

Note: Percentage (\%), and numbers of the respondents (N)

Similarly, the majority of in-service beginner art teachers have positive opinions and feelings toward being able to contact other art teachers in the same school $(29.8 \%, n$ =37). Consequently, positive opinions and feelings were also reported toward being able to contact with other art teachers in the other school $(33.9 \%, n=42)$. Admittedly, that the more experience art teaches have the more knowledge they will gain about other schools and others art teachers.

Table 13 
I have contact with other art teachers either in the same school or in other schools (Inservice beginner art teachers)

\begin{tabular}{|c|l|l|l|l|l|l|l|l|}
\hline$\#$ & Statement & $\mathrm{SD}$ & $\mathrm{D}$ & $\mathrm{DK}$ & $\mathrm{A}$ & $\mathrm{SA}$ & Total \\
\hline 1 & $\begin{array}{l}\text { I have contact with other art teachers in } \\
\text { the same school }\end{array}$ & $\mathrm{N}$ & 28 & 24 & 8 & 37 & 27 & 124 \\
\cline { 3 - 10 } & $\%$ & 22.6 & 19.4 & 6.5 & 29.8 & 21.8 & 100.0 \\
\hline 2 & $\begin{array}{l}\text { I have contact with other art teachers in } \\
\text { other schools }\end{array}$ & $\mathrm{N}$ & 21 & 23 & 9 & 42 & 29 & 124 \\
\cline { 3 - 10 } & $\%$ & 16.9 & 18.5 & 7.3 & 33.9 & 23.4 & 100.0 \\
\hline
\end{tabular}

Note: Percentage (\%), and numbers of the respondents (N)

Similarly to in-service beginner art teachers, the majority of in-service advanced art teachers have a positive attitude toward being able to contact other art teachers in the same school $(30.0 \%, n=42)$. And, positive opinions and feelings were reported toward being able to contact with other art teachers in the other school $(38.6 \%, n=54)$.

\section{Table 14}

I have contact with other art teachers either in the same school or in other schools (Inservice advanced art teachers)

\begin{tabular}{|c|l|l|l|l|l|l|l|l|}
\hline$\#$ & Statement & $\mathrm{SD}$ & $\mathrm{D}$ & $\mathrm{DK}$ & $\mathrm{A}$ & $\mathrm{SA}$ & Total \\
\hline 1 & $\begin{array}{l}\text { I have contact with other art teachers } \\
\text { in the same school }\end{array}$ & $\mathrm{N}$ & 15 & 32 & 17 & 42 & 34 & 140 \\
\cline { 3 - 10 } & $\%$ & 10.7 & 22.9 & 12.1 & 30.0 & 24.3 & 100.0 \\
\hline 2 & $\begin{array}{l}\text { I have contact with other art teachers } \\
\text { in other schools }\end{array}$ & $\mathrm{N}$ & 14 & 29 & 13 & 54 & 30 & 140 \\
\cline { 4 - 10 } & $\%$ & 10.0 & 20.7 & 9.3 & 38.6 & 21.4 & 100.0 \\
\hline
\end{tabular}

Note: Percentage (\%), and numbers of the respondents (N)

Positive and negative opinions and feelings were reported in the results. The majority of pre-service art teachers groups showed positive opinions and feelings toward the availability of having adequate budget for their equipment and supplies $(26.1 \%, n=$ 
18). Similarly, the majority of in-service advanced art teachers reported positive feelings $(26.4 \%, n=37)$. However the majority of in-service beginner art teachers reported negative feelings toward the availability of having adequate budget for their equipment and supplies $(29.8 \%, n=37)$.

\section{Table 15}

I have adequate budget for equipment and supplies

\begin{tabular}{|l|l|l|l|l|l|l|l|l|}
\hline$\#$ & \multicolumn{2}{|l|}{$\begin{array}{l}\text { I have adequate budget for equipment and } \\
\text { supplies }\end{array}$} & SD & D & DK & A & SA & Total \\
\hline 1 & Pre-Service Art Teachers & $\mathrm{N}$ & 16 & 17 & 15 & 18 & 3 & 69 \\
\cline { 3 - 9 } & & $\%$ & 23.2 & 24.6 & 21.7 & 26.1 & 4.3 & 100 \\
\hline 2 & In-Service Beginner Art Teachers & $\mathrm{N}$ & 33 & 37 & 11 & 34 & 9 & 124 \\
\cline { 3 - 9 } & & $\%$ & 26.6 & 29.8 & 8.9 & 27.4 & 7.3 & 100 \\
\hline 3 & In-Service Advanced Art Teachers & $\mathrm{N}$ & 29 & 31 & 19 & 37 & 24 & 140 \\
\cline { 3 - 8 } & $\%$ & 20.7 & 22.1 & 13.6 & 26.4 & 17.1 & 100 \\
\hline
\end{tabular}

Positive opinions were reported among the three groups. The majority of preservice art teachers group reported positive opinions toward having enough time for preparation for teaching $(31.9 \%, n=22)$. Similarly, The majority of in-service beginner art teachers reported positive opinions $(35.5 \%, n=44)$, and the majority of in-service advanced art teachers also reported positive opinions $(40.7 \%, n=57)$. No doubt everyone was able to have enough time for preparation for teaching.

\section{Table 16}

I have enough time for preparation for teaching.

\begin{tabular}{|l|l|l|l|l|l|l|l|}
\hline$\#$ & $\begin{array}{l}\text { I have enough time for preparation for } \\
\text { teaching. }\end{array}$ & SD & D & DK & A & SA & Total \\
\hline
\end{tabular}




\begin{tabular}{|c|c|c|c|c|c|c|c|c|}
\hline \multirow[t]{2}{*}{1} & \multirow[t]{2}{*}{ Pre-Service Art Teachers } & $\mathrm{N}$ & 12 & 12 & 13 & 22 & 10 & 69 \\
\hline & & $\%$ & 17.4 & 17.4 & 18.8 & 31.9 & 14.5 & 100 \\
\hline \multirow{2}{*}{2} & \multirow{2}{*}{ In-Service Beginner Art Teachers } & $\mathrm{N}$ & 20 & 16 & 12 & 44 & 32 & 124 \\
\hline & & $\%$ & 16.1 & 12.9 & 9.7 & 35.5 & 25.8 & 100 \\
\hline \multirow[t]{2}{*}{3} & \multirow[t]{2}{*}{ In-Service Advanced Art Teachers } & $\mathrm{N}$ & 13 & 26 & 12 & 57 & 32 & 140 \\
\hline & & $\%$ & 9.3 & 18.6 & 8.6 & 40.7 & 22.9 & 100 \\
\hline
\end{tabular}

Respondents were asked to rate the most influential person during their teacher training. Different influential people were reported. The majority of pre-service art teachers reported that their classmates and other art teachers were the most influential people during their teacher training by $44.9 \%(n=31)$ of the respondents.

\section{Table 17}

Describe the most influential person during your teacher training (Pre-service art teachers)

\begin{tabular}{|c|l|l|l|l|l|l|l|l|}
\hline$\#$ & Statement & $\mathrm{SD}$ & $\mathrm{D}$ & $\mathrm{DK}$ & $\mathrm{A}$ & $\mathrm{SA}$ & Total \\
\hline 1 & $\begin{array}{l}\text { My supervisor was the most influential } \\
\text { person during my teacher training. }\end{array}$ & $\mathrm{N}$ & 8 & 11 & 15 & 18 & 17 & 69 \\
\cline { 5 - 11 } & $\%$ & 11.6 & 15.9 & 21.7 & 26.1 & 24.6 & 100.0 \\
\hline 2 & $\begin{array}{l}\text { My classmates and other art teachers } \\
\text { were the most influential people } \\
\text { during my teacher training. }\end{array}$ & $\mathrm{N}$ & 5 & 6 & 14 & 31 & 13 & 69 \\
\cline { 5 - 11 } & $\%$ & 7.2 & 8.7 & 20.3 & 44.9 & 18.8 & 100.0 \\
\hline 3 & $\begin{array}{l}\text { My art education professor was the } \\
\text { most influential person during my } \\
\text { teacher training. }\end{array}$ & $\mathrm{N}$ & 6 & 5 & 7 & 30 & 21 & 69 \\
\cline { 5 - 10 } & $\%$ & 8.7 & 7.2 & 10.1 & 43.5 & 30.4 & 100.0 \\
\hline
\end{tabular}

Note: Percentage (\%), and numbers of the respondents (N)

The majority of in-service beginner art teachers reported that their supervisor was the most influential person during their teacher training by $36.3 \%(n=45)$ of the respondents. 
Table 18

Describe the most influential person during your teacher training (In-service beginner art teachers)

\begin{tabular}{|c|l|l|l|l|l|l|l|l|}
\hline$\#$ & Statement & $\mathrm{SD}$ & $\mathrm{D}$ & $\mathrm{DK}$ & $\mathrm{A}$ & $\mathrm{SA}$ & Total \\
\hline 1 & $\begin{array}{l}\text { My supervisor was the most influential } \\
\text { person during my teacher training. }\end{array}$ & $\mathrm{N}$ & 17 & 21 & 12 & 45 & 29 & 124 \\
\cline { 5 - 10 } & $\%$ & 13.7 & 16.9 & 9.7 & 36.3 & 23.4 & 100.0 \\
\hline 2 & $\begin{array}{l}\text { My classmates and other art teachers } \\
\text { were the most influential people } \\
\text { during my teacher training. }\end{array}$ & $\mathrm{N}$ & 15 & 30 & 20 & 28 & 31 & 124 \\
\cline { 3 - 10 } 3 & $\%$ & 12.1 & 24.2 & 16.1 & 22.6 & 25.0 & 100.0 \\
\hline & $\begin{array}{l}\text { My art education professor was the } \\
\text { most influential person during my } \\
\text { teacher training. }\end{array}$ & $\mathrm{N}$ & 18 & 36 & 12 & 30 & 28 & 124 \\
\cline { 2 - 10 } & $\%$ & 14.5 & 29.0 & 9.7 & 24.2 & 22.6 & 100.0 \\
\hline
\end{tabular}

Note: Percentage (\%), and numbers of the respondents $(\mathrm{N})$

The majority of in-service advanced art teachers reported that their art education professor was the most influential person during their teacher training by $36.4 \% \%(n=51)$ of the respondents.

Table 19

Describe the most influential person during your teacher training (In-service advanced art teachers)

\begin{tabular}{|c|c|c|c|c|c|c|c|c|}
\hline$\#$ & Statement & & SD & $\mathrm{D}$ & $\mathrm{DK}$ & A & SA & Total \\
\hline \multirow[t]{2}{*}{1} & \multirow{2}{*}{$\begin{array}{l}\text { My supervisor was the most influential } \\
\text { person during my teacher training. }\end{array}$} & $\mathrm{N}$ & 14 & 26 & 18 & 49 & 33 & 140 \\
\hline & & $\%$ & 10.0 & 18.6 & 12.9 & 35.0 & 23.6 & 100.0 \\
\hline \multirow[t]{2}{*}{2} & \multirow{2}{*}{$\begin{array}{l}\text { My classmates and other art teachers } \\
\text { were the most influential people } \\
\text { during my teacher training. }\end{array}$} & $\mathrm{N}$ & 14 & 31 & 14 & 50 & 31 & 140 \\
\hline & & $\%$ & 10.0 & 22.1 & 10.0 & 35.7 & 22.1 & 100.0 \\
\hline \multirow[t]{2}{*}{3} & \multirow{2}{*}{$\begin{array}{l}\text { My art education professor was the } \\
\text { most influential person during my } \\
\text { teacher training. }\end{array}$} & $\mathrm{N}$ & 18 & 15 & 21 & 51 & 35 & 140 \\
\hline & & $\%$ & 12.9 & 10.7 & 15.0 & 36.4 & 25.0 & 100.0 \\
\hline
\end{tabular}

Note: Percentage (\%), and numbers of the respondents (N) 
Positive opinions and feelings toward teacher training effectiveness occurred among pre-service art teachers. The majority agreed that their teacher training during the field experience course was very effective $(34.8 \%, n=24)$, and their teacher training needs to be improved $(342.0 \%, n=29)$.

Table 20

Teacher training effectiveness (Pre-service art teachers)

\begin{tabular}{|c|l|l|l|l|l|l|l|l|}
\hline$\#$ & Statement & $\mathrm{SD}$ & $\mathrm{D}$ & $\mathrm{DK}$ & $\mathrm{A}$ & $\mathrm{SA}$ & Total \\
\hline 1 & $\begin{array}{l}\text { My teacher training during the field } \\
\text { experience course was very effective. }\end{array}$ & $\mathrm{N}$ & 5 & 7 & 20 & 24 & 13 & 69 \\
\cline { 5 - 10 } & $\%$ & 7.2 & 10.1 & 29.0 & 34.8 & 18.8 & 100.0 \\
\hline 2 & $\begin{array}{l}\text { My teacher training needs to be } \\
\text { improved. }\end{array}$ & $\mathrm{N}$ & 2 & 10 & 9 & 29 & 19 & 69 \\
\cline { 3 - 10 } 3 & $\begin{array}{l}\text { My teacher training does not need to } \\
\text { be changed. }\end{array}$ & $\mathrm{N}$ & 20 & 28 & 11 & 8 & 2 & 69 \\
\cline { 2 - 10 } & $\%$ & 29.0 & 40.6 & 15.9 & 11.6 & 2.9 & 100.0 \\
\hline
\end{tabular}

Note: Percentage (\%), and numbers of the respondents (N)

Just in the same way of the pre-service art teachers group, positive opinions and feelings toward teacher training effectiveness occurred among in-service beginner art teachers. The majority agreed that their teacher training during the field experience course was very effective $(34.7 \%, n=41)$, and their teacher training needs to be improved $(34.7 \%, n=43)$.

Table 21

Teacher training effectiveness (In-service beginner art teachers) 


\begin{tabular}{|c|l|l|l|l|l|l|l|l|}
\hline$\#$ & Statement & $\mathrm{SD}$ & $\mathrm{D}$ & $\mathrm{DK}$ & $\mathrm{A}$ & $\mathrm{SA}$ & Total \\
\hline 1 & $\begin{array}{l}\text { My teacher training during the field } \\
\text { experience course was very effective. }\end{array}$ & $\mathrm{N}$ & 25 & 23 & 7 & 41 & 28 & 124 \\
\cline { 5 - 10 } & $\%$ & 20.2 & 18.5 & 5.6 & 33.1 & 22.6 & 100.0 \\
\hline 2 & $\begin{array}{l}\text { My teacher training needs to be } \\
\text { improved. }\end{array}$ & $\mathrm{N}$ & 18 & 20 & 13 & 43 & 30 & 124 \\
\cline { 2 - 10 } 3 & $\begin{array}{l}\text { My teacher training does not need to } \\
\text { be changed. }\end{array}$ & $\mathrm{N}$ & 28 & 30 & 17 & 30 & 19 & 124 \\
\cline { 5 - 10 } & $\%$ & 22.6 & 24.2 & 13.7 & 24.2 & 15.3 & 100.0 \\
\hline
\end{tabular}

Note: Percentage (\%), and numbers of the respondents (N)

As well pre-service art teachers group and in-service beginner art teachers group, the majority of in-service advanced art teachers group also reported positive opinions and feelings toward teacher training effectiveness occurred among in-service beginner art teachers. The majority agreed that their teacher training during the field experience course was very effective $(32.9 \%, n=46)$, and their teacher training needs to be improved $(42.9 \%, n=60)$.

Table 22

Teacher training effectiveness (In-service advanced art teachers)

\begin{tabular}{|l|l|l|l|l|l|l|l|l|}
\hline$\#$ & Statement & $\mathrm{SD}$ & $\mathrm{D}$ & $\mathrm{DK}$ & $\mathrm{A}$ & $\mathrm{SA}$ & Total \\
\hline 1 & $\begin{array}{l}\text { My teacher training during the field } \\
\text { experience course was very effective. }\end{array}$ & $\mathrm{N}$ & 19 & 19 & 21 & 46 & 35 & 140 \\
\cline { 5 - 10 } & & $\%$ & 13.6 & 13.6 & 15.0 & 32.9 & 25.0 & 100.0 \\
\hline 2 & $\begin{array}{l}\text { My teacher training needs to be } \\
\text { improved. }\end{array}$ & $\mathrm{N}$ & 7 & 15 & 16 & 60 & 42 & 140 \\
\cline { 3 - 10 } 3 & $\begin{array}{l}\text { My teacher training does not need to } \\
\text { be changed. }\end{array}$ & $\mathrm{N}$ & 33 & 46 & 22 & 24 & 15 & 140 \\
\cline { 5 - 10 } & $\%$ & 23.6 & 32.9 & 15.7 & 17.1 & 10.7 & 100.0 \\
\hline
\end{tabular}

Note: Percentage (\%), and numbers of the respondents (N) 
The majority of pre-service art teachers group reported positive opinions and feelings toward the length of the field experience course $(42.0 \%, n=29)$. Yet, equally positive and negative feelings were reported toward the willing to have a longer field experience courses before entering their first classroom $(30.4 \%, n=21)$.

Table 23

Field experience course length (Pre-service art teachers)

\begin{tabular}{|l|l|l|l|l|l|l|l|l|}
\hline$\#$ & Statement & $\mathrm{SD}$ & $\mathrm{D}$ & $\mathrm{DK}$ & $\mathrm{A}$ & $\mathrm{SA}$ & Total \\
\hline 1 & $\begin{array}{l}\text { My field experience course length was } \\
\text { perfect. }\end{array}$ & $\mathrm{N}$ & 4 & 12 & 12 & 29 & 12 & 69 \\
\cline { 2 - 11 } & $\%$ & 5.8 & 17.4 & 17.4 & 42.0 & 17.4 & 100.0 \\
\hline 2 & $\begin{array}{l}\text { I would like to have a longer field } \\
\text { experience courses before entering my } \\
\text { first classroom. }\end{array}$ & $\mathrm{N}$ & 7 & 21 & 8 & 21 & 12 & 69 \\
\cline { 2 - 11 } & $\%$ & 10.1 & 30.4 & 11.6 & 30.4 & 17.4 & 100.0 \\
\hline
\end{tabular}

Note: Percentage (\%), and numbers of the respondents (N)

On the other hand, the majority of in-service beginner art teachers group reported negative feelings toward the length of the field experience course $(29.8 \%, n=37)$.

Nevertheless, positive feelings were reported toward the willing to have a longer field experience courses before entering their first classroom $(33.9 \%, n=42)$.

Table 24

Field experience course length (In-service beginner art teachers)

\begin{tabular}{|l|l|l|l|l|l|l|l|l|}
\hline$\#$ & Statement & $\mathrm{SD}$ & $\mathrm{D}$ & $\mathrm{DK}$ & $\mathrm{A}$ & $\mathrm{SA}$ & Total \\
\hline 1 & $\begin{array}{l}\text { My field experience course length was } \\
\text { perfect. }\end{array}$ & $\mathrm{N}$ & 30 & 37 & 13 & 26 & 18 & 124 \\
\cline { 2 - 10 } & & $\%$ & 24.2 & 29.8 & 10.5 & 21.0 & 14.5 & 100.0 \\
\hline 2 & I would like to have a longer field & $\mathrm{N}$ & 18 & 17 & 7 & 40 & 42 & 124 \\
\hline
\end{tabular}




\begin{tabular}{|l|l|l|l|l|l|l|l|l|}
\hline $\begin{array}{l}\text { experience courses before entering my } \\
\text { first classroom. }\end{array}$ & $\%$ & 14.5 & 13.7 & 5.6 & 32.2 & 33.9 & 100.0 \\
\hline
\end{tabular}

Note: Percentage (\%), and numbers of the respondents $(\mathrm{N})$

Similarly, the majority of in-service advanced art teachers group reported negative feelings toward the length of the field experience course $(42.1 \%, n=59)$. Further, positive feelings were reported toward the willing to have a longer field experience courses before entering their first classroom $(40.0 \%, n=56)$.

Table 25

Field experience course length (In-service advanced art teachers)

\begin{tabular}{|c|l|l|l|l|l|l|l|l|}
\hline$\#$ & Statement & $\mathrm{SD}$ & $\mathrm{D}$ & $\mathrm{DK}$ & $\mathrm{A}$ & $\mathrm{SA}$ & Total \\
\hline 1 & $\begin{array}{l}\text { My field experience course length was } \\
\text { perfect. }\end{array}$ & $\mathrm{N}$ & 22 & 59 & 22 & 25 & 12 & 140 \\
\cline { 2 - 10 } & $\%$ & 15.7 & 42.1 & 15.7 & 17.9 & 8.6 & 100.0 \\
\hline 2 & $\begin{array}{l}\text { I would like to have a longer field } \\
\text { experience courses before entering my } \\
\text { first classroom. }\end{array}$ & $\mathrm{N}$ & 11 & 22 & 15 & 56 & 36 & 140 \\
\cline { 2 - 10 } & $\%$ & 7.9 & 15.7 & 10.7 & 40.0 & 25.7 & 100.0 \\
\hline
\end{tabular}

Note: Percentage (\%), and numbers of the respondents (N)

Positive opinions and feelings were reported among the three groups. The majority of pre-service art teachers group reported positive feelings to become an art teacher again, given the opportunity to start over $(31.9 \%, n=22)$. Similarly, the majority of in-service beginner art teachers reported positive feelings $(32.3 \%, n=40)$, and the majority of in-service advanced art teachers also reported positive feelings $(32.1 \%, n=$ 45). It is easy to see that everyone is willing to become an art teacher again, given the opportunity to start over. 
Table 26

I would become an art teacher again, given the opportunity to start over.

\begin{tabular}{|l|l|l|l|l|l|l|l|l|}
\hline$\#$ & \multicolumn{2}{|l|}{$\begin{array}{l}\text { I would become an art teacher again, given } \\
\text { the opportunity to start over }\end{array}$} & $\mathrm{SD}$ & $\mathrm{D}$ & $\mathrm{DK}$ & $\mathrm{A}$ & $\mathrm{SA}$ & Total \\
\hline 1 & Pre-Service Art Teachers & $\mathrm{N}$ & 7 & 13 & 7 & 20 & 22 & 69 \\
\cline { 3 - 9 } & $\%$ & 10.1 & 18.8 & 10.1 & 29.0 & 31.9 & 100 \\
\hline 2 & In-Service Beginner Art Teachers & $\mathrm{N}$ & 14 & 16 & 24 & 40 & 30 & 124 \\
\cline { 3 - 9 } & & $\%$ & 11.3 & 12.9 & 19.4 & 32.3 & 24.2 & 100 \\
\hline 3 & In-Service Advanced Art Teachers & $\mathrm{N}$ & 19 & 23 & 20 & 45 & 33 & 140 \\
\cline { 3 - 8 } & $\%$ & 13.6 & 16.4 & 14.3 & 32.1 & 23.6 & 100 \\
\hline
\end{tabular}

\section{Part Four}

\section{Research Questions}

How do pre-service, beginner, and advanced art teachers in Kuwait describe and evaluate their teacher preparation program?

The supporting questions:

1. What are the perceptions of pre-service, beginner, and advanced art teachers in Kuwait regarding the theoretical and practical training they received in their teacher education programs?

2. What are the pre-service, beginner, and advanced art teachers in Kuwait feelings regarding how well they think their education prepared them for their current positions?

3. What are the pre-service, beginner, and advanced art teachers in Kuwait feelings regarding the effectiveness of their field experience courses and how it prepared them for their teaching practice during their first years?

4. What are the perceptions of pre-service, beginner, and advanced art teachers in Kuwait 
regarding what beginning art teachers should know and be able to do and how well they thought their education prepared them for their current position?

5. What are the pre-service, beginners, and advanced art teachers in Kuwait feelings towards the most influencing person during their teacher training?

In this part, the data is sub-scaled into five categories according to the research questions. In sub-scale number 1 and 4, the lower Mean (below 3.00) is positive and the higher Mean (above 3.00) is negative. One the other hand, subscale number 2, 3, and 5, the higher Mean (above 0.) is positive and the lower Mean (below 0.) is negative.

In responded to the first research question, the perceptions of pre-service, beginner, and advanced art teachers in Kuwait regarding the theoretical and practical training they received in their teacher education programs, pre-service art teachers $(\mathrm{M}=2.2246, n=69)$, in service beginner $(\mathrm{M}=2.7581, n=124)$ and advanced $(\mathrm{M}=2.6762$, $n=140)$ art teachers reported positively.

The result of the second research question, the pre-service, beginner, and advanced art teachers in Kuwait feelings regarding how well they think their education prepared them for their current positions, only in-service beginner $(\mathrm{M}=.1081, n=124)$ and in-service advanced art teachers $(\mathrm{M}=2.6762, n=140)$ reported positively. On the contrary pre-service art teachers reported negatively $(\mathrm{M}=-.1130, n=69)$.

The third research question, the pre-service, beginner, and advanced art teachers in Kuwait feelings regarding the effectiveness of their field experience courses and how it prepared them for their teaching practice during their first years, only pre-service art 
teachers reported positive $(\mathrm{M}=.1123, n=69)$. In-service beginner $(\mathrm{M}=-.2681, n=124)$

and in-service advanced art teachers $(\mathrm{M}=-.1482, n=140)$ reported negatively.

The fourth research question, the perceptions of pre-service, beginner, and advanced art teachers in Kuwait regarding what beginning art teachers should know and be able to do and how well they thought their education prepared them for their current position, indicated positive results among the three groups. Pre-service art teachers reported $(\mathrm{M}=2.2174, n=69)$, in-service beginner art teacher reported $(\mathrm{M}=2.9133, n=$ 124), and in-service advanced art teachers reported $(\mathrm{M}=2.7792, n=140)$.

Lastly, the fifth research question, the pre-service, beginner, and advanced art teachers in Kuwait feelings towards the most influencing person during their teacher training, showed positive impact among the three groups. Pre-service art teachers reported $(\mathrm{M}=.4928, n=69)$, in-service beginner art teacher reported $(\mathrm{M}=.2226, n=124)$, and in-service advanced art teachers reported $(M=.4129, n=140)$.

\section{Table 27}

Shows the results.

\begin{tabular}{|c|l|l|l|l|l|l|l|}
\hline$\#$ & Pre-service/In-Service Teacher & $\mathrm{Q} 1$ & $\mathrm{Q} 2$ & $\mathrm{Q} 3$ & $\mathrm{Q} 4$ & $\mathrm{Q} 5$ \\
\hline 1 & Pre-Service Art Teachers & $\mathrm{N}$ & 69 & 69 & 69 & 69 & 69 \\
\cline { 3 - 8 } & & Mean & 2.2246 & -.1130 & .1123 & 2.2174 & .4928 \\
\hline 2 & $\begin{array}{l}\text { In-Service Beginner Art } \\
\text { Teachers }\end{array}$ & $\mathrm{N}$ & 124 & 124 & 124 & 124 & 124 \\
\cline { 3 - 8 } 3 & $\mathrm{Mean}$ & 2.7581 & .1081 & -.2681 & 2.9133 & .2226 \\
\hline $\begin{array}{l}\text { In-Service Advanced Art } \\
\text { Teachers }\end{array}$ & $\mathrm{N}$ & 140 & 140 & 140 & 140 & 140 \\
\cline { 3 - 8 } & Mean & 2.6762 & 2.6762 & -.1482 & 2.7792 & .4129 \\
\hline
\end{tabular}




\section{Part Five: Qualitative Data Analysis}

Bowen stated in her article "document analysis involves skimming, reading, and interpretation" (Bowen, 2009, p.32). According to Hsieh, content analysis is a widely used in qualitative research (Hsieh, 2005). Hsied added, content analysis allows interpreting meaning from the content of text. This study used the summative content analysis because it involves comparisons between the content followed by the interpretation of the underlying context. An examination of the Web pages of both the $\mathrm{MOE}$ and $\mathrm{CBE}$ mission goals was conducted to gather information regarding the similarity and the differences between both general mission goals.

A chart designed by the researcher to clarify and describe the content comparison between the College of Basic Education and the Ministry of Education in Kuwait.

Table 28

\begin{tabular}{|c|c|c|c|}
\hline \# & Mission Statement & $\begin{array}{l}\text { Ministry of Education } \\
\text { Art Education }\end{array}$ & $\begin{array}{l}\text { College of Basic } \\
\text { Education } \\
\text { Art Education }\end{array}$ \\
\hline 1 & The overall goal & $\begin{array}{l}\text { Create appropriate } \\
\text { opportunities to } \\
\text { help individuals for } \\
\text { a total grow, in } \\
\text { light of the nature } \\
\text { of the Kuwaiti } \\
\text { society, } \\
\text { philosophy, and } \\
\text { hopes, and of the } \\
\text { principles of Islam, } \\
\text { Arab heritage, and } \\
\text { contemporary }\end{array}$ & $\begin{array}{l}\text { Guide the learners } \\
\text { to understand the } \\
\text { definition of } \\
\text { aesthetic and } \\
\text { artistic values of } \\
\text { the environment } \\
\text { and culture based } \\
\text { on the capabilities } \\
\text { of learners to } \\
\text { develop creative } \\
\text { artworks. } \\
\text { - Identify the }\end{array}$ \\
\hline
\end{tabular}




\begin{tabular}{|c|c|c|c|}
\hline & & $\begin{array}{l}\text { culture. } \\
\text { Create a balance } \\
\text { achieving between } \\
\text { individuals and } \\
\text { Kuwaiti society in } \\
\text { particular and the } \\
\text { Arab community } \\
\text { and the world at } \\
\text { large. }\end{array}$ & $\begin{array}{l}\text { materials of the } \\
\text { environment and } \\
\text { its relationship to } \\
\text { the methods of the } \\
\text { Fine Arts and } \\
\text { work. }\end{array}$ \\
\hline 2 & $\begin{array}{l}\text { Religious identity and } \\
\text { national belonging }\end{array}$ & $\begin{array}{l}\text { Establish an } \\
\text { artistic growth of } \\
\text { the learner within } \\
\text { the framework of } \\
\text { our Islamic } \\
\text { religion. } \\
\text { - Establish a national } \\
\text { belonging of the } \\
\text { learner. }\end{array}$ & $\begin{array}{l}\text { Familiarize } \\
\text { students to work } \\
\text { with different } \\
\text { materials } \\
\text { especially } \\
\text { materials that are } \\
\text { connected to his } \\
\text { or her homeland } \\
\text { environment to } \\
\text { foster his or her } \\
\text { national } \\
\text { belonging. }\end{array}$ \\
\hline 3 & Art production & $\begin{array}{l}\text { Acknowledge the } \\
\text { learner with the } \\
\text { experience, skills, } \\
\text { and knowledge } \\
\text { that he or she will } \\
\text { need according to } \\
\text { his or her ability to } \\
\text { learn and age. } \\
\text { Develop a creative } \\
\text { expressive through } \\
\text { creative thinking } \\
\text { and imagination. }\end{array}$ & $\begin{array}{l}\text { Encourage the } \\
\text { learners to use } \\
\text { their senses to be } \\
\text { creative. }\end{array}$ \\
\hline 4 & Art taste & $\begin{array}{l}\text { Enrich the artistic } \\
\text { awareness of } \\
\text { learning through } \\
\text { recognizing the } \\
\text { aesthetic values in } \\
\text { order to affect his } \\
\text { or her behavior. }\end{array}$ & $\begin{array}{l}\text { Develop an } \\
\text { artistic taste of the } \\
\text { aesthetic values } \\
\text { and to express } \\
\text { their opinion. }\end{array}$ \\
\hline 5 & Art History & $\begin{array}{l}\text { Acknowledged } \\
\text { about art history, } \\
\text { Islamic Heritage } \\
\text { art, and the artistic }\end{array}$ & $\begin{array}{l}\text { Recognize the } \\
\text { diverse culture } \\
\text { and identify the } \\
\text { artistic value }\end{array}$ \\
\hline
\end{tabular}




\begin{tabular}{|c|c|c|c|}
\hline & & heritage of Kuwait. & around the globe. \\
\hline 6 & Art criticism & $\begin{array}{l}\text { Define the critical } \\
\text { thinking through } \\
\text { describing and } \\
\text { analyzing works of } \\
\text { art. }\end{array}$ & $\begin{array}{l}\text { Encourage } \\
\text { learners to gain } \\
\text { critical thinking. }\end{array}$ \\
\hline 7 & $\begin{array}{l}\text { Communication and } \\
\text { Collaboration }\end{array}$ & $\begin{array}{l}\text { Create artistic } \\
\text { achievement } \\
\text { through the } \\
\text { possibility to } \\
\text { participate in } \\
\text { exhibitions and art } \\
\text { competitions } \\
\text { internal and } \\
\text { external. }\end{array}$ & \\
\hline 8 & $\begin{array}{l}\text { Feeling and emotion } \\
\text { development }\end{array}$ & & $\begin{array}{l}\text { Develop the } \\
\text { emotional and } \\
\text { sentimental } \\
\text { aspects by } \\
\text { practicing the } \\
\text { artwork, which } \\
\text { helps for a sense } \\
\text { of well being that } \\
\text { adapt from the } \\
\text { surrounding } \\
\text { environment. }\end{array}$ \\
\hline 9 & Professional life & & $\begin{array}{l}\text { - Achieving and } \\
\text { developing the } \\
\text { educational value } \\
\text { of work. }\end{array}$ \\
\hline 10 & $\begin{array}{l}\text { Gifted and talented } \\
\text { learners }\end{array}$ & & $\begin{array}{l}\text { - Support gifted and } \\
\text { talented students. }\end{array}$ \\
\hline 11 & Beauty & & $\begin{array}{l}\text { Help to create and } \\
\text { build beautiful } \\
\text { environment and } \\
\text { community. }\end{array}$ \\
\hline 12 & Spare time & & $\begin{array}{l}\text { Motivate the } \\
\text { learners to work } \\
\text { on producing art } \\
\text { during their spare } \\
\text { time. }\end{array}$ \\
\hline
\end{tabular}


The chart above described both MOE and CBE mission statements. The first statement is about the overall goal. As stated in both web sites, the overall goal is different between them. MOE encourage their teacher to create appropriate opportunities to help individuals for a total grow, in light of the nature of the Kuwaiti society, philosophy, and hopes, and of the principles of Islam, Arab heritage, and contemporary culture, and to create a balance achieving between individuals and Kuwaiti society in particular and the Arab community and the world at large. The MOE focused on the individuals' growth within their awareness of the nature of the Kuwaiti society in particular and the Arab community and the world at large.

Whereas the CBE focuses on the awareness and development of the fine arts itself and guides the learners to understand the definition of aesthetic and artistic values of the environment and culture based on the capabilities of learners to develop creative artworks, and to identify the materials of the environment and its relationship to the methods of the fine arts and work.

The second mission statement is similar to both MOE and CBE. They both encourage their students and teachers to connect their art work with their national belonging and religion identity. The third mission statement is related to the art production and it is similar in both MOE and CBE. They both encourage their learners to use, express, and develop their sense to be creative. The fourth mission statement is related to the art taste and it is also similar in both MOE and CBE. They both encourage 
their learners to enrich and develop an artistic taste of the aesthetic values and to express their opinion.

The fifth mission statement is related to the art history and it is different in both MOE and CBE. The MOE encourage their art teachers to be acknowledged about art history, Islamic Heritage art, and the artistic heritage of Kuwait. Whereas CEB encourages their students recognize the diverse culture and identify the artistic value around the globe. The sixth mission statement is related to the art criticism and it is also similar in both MOE and CBE. They both encourage their learners to gain critical thinking.

The seventh mission statement is related to the communication and collaboration. It only exists in the MOE missions' statements. It encourages art teachers to create artistic achievement through the possibility to participate in exhibitions and art competitions internal and external. Even though the CBE don't have the participation in exhibitions and art competitions internal and external in their mission statement, they do organize and support a yearly art exhibition for their art students.

The eight-mission statement is related to the feeling and emotion development. It is only exists in the CBE missions' statements board. This statement designed to help develop the emotional and sentimental aspects by practicing the artwork, which helps for a sense of well being that adapt from the surrounding environment. The ninth mission statement is related to the professional life of the art teachers. It is also only exists in the 
CBE missions' statements board, and it focuses on achieving and developing the educational value of work.

The tenth mission statement is related to support the gifted and talented learners, and it is only exists in the CBE missions' statements board. The eleventh mission statement is about beauty in art. It only exists in the CBE missions' statements board. This mission designed to help to create and build beautiful environment and community Lastly the twelve's mission statement is about spare time. It only exists in the CBE missions' statements board. This mission designed to motivate the learners to work on producing art during their spare time.

There are strong connection between MOE and CBE in Kuwait. Students who complete all the requirements at CBE can be successfully employed in the Ministry of Education and practice their teaching. As stated in Al-Najar study, "The Ministry of Education in Kuwait maintains that improving the quality of the art curriculum has been a major focus of art educators" (2001, p.15). The MOE in Kuwait encouraged doing more research on art education in order to improve the quality of art education. Al-Najar also stated that, "The Ministry has set up objectives and guidelines for art teaching to ensure effective art education in schools" (2001, p.15). Eventhogh both MOE and CBE worked together to ensure the quality of art education, some art teachers graduate from the college of education and are well prepared to teach art in schools; others are not well prepared, even though they graduated from the same program. Examining both the MOE and CBE mission goals was conducted to gather information regarding the similarity and 
the differences between both general mission goals.

There are some similarities between MOE and CBE mission statements but there are some contrasts between them. These differences may cause missing information that may lead to confused beginner's art teachers or may build a gap between the only two institutions in the field of art education in Kuwait. Darweesh clarified that the CBE preparation courses did not fully serve the curriculum that the Kuwaiti Ministry of Education (MOE) requires art teachers to teach (Darweesh, 2010). Therefore, beginner art teachers struggle and face a serious problems because what they are prepared to do as pre-service students did not meet what they are seeing and facing in their everyday teaching practice.

Recommendations of this study are to encourage having similar mission statements in both $\mathrm{CBE}$ and MOE so that pre-service and in-service art teachers won't be confused during their first year of teaching. 


\section{Chapter Five \\ CONCLUSIONS AND DISCUSSION OF THE RESULTS}

This chapter discusses the findings of the present study that examined how preservice, beginning, and advanced art teachers in Kuwait view their teacher preparation program. This study used quantitative and qualitative research approaches. The study included a qualitative document analysis and a quantitative survey of pre-service art education teachers who have completed their classroom observation at the end of the fourth year at College of Basic of Education CBE, beginning art education teachers who are teaching in the first of their second year at the Ministry of Education in Kuwait MOE, and advance art teachers who are ready to teach in the beginning of their fourth year at the Ministry of Education in Kuwait MOE, to provide a description of the art education program in the college of Basic Education from which the teachers graduated.

A total of 333 in-service and pre-service art teachers participated in the study. Descriptive statistics were generated to summarize the quantitative data. Mean ratings of teachers' sense of their preparedness were compared. Perceptions of the 333 participants of the effectiveness of the teacher education program in the State of Kuwait have been presented in this study for consideration for those who concerned with the improvement of the training of art teachers, and to offer suggestions for program improvement and the design of local curricular guidelines for the future of the art teacher programs.

The data are used here to answer the following research question and supporting 
questions that have guided this study.

\section{Research Question}

The guiding question of this study is: How do pre-service, beginner, and advanced art teachers in Kuwait describe and evaluate their teacher preparation program?

The supporting questions are:

1. What are the perceptions of pre-service, beginner, and advanced art teachers in Kuwait regarding the theoretical and practical training they received in their teacher education programs?

2. What are the pre-service, beginner, and advanced art teachers in Kuwait feelings regarding how well they think their education prepared them for their current positions? 3. What are the pre-service, beginner, and advanced art teachers in Kuwait feelings regarding the effectiveness of their field experience courses and how it prepared them for their teaching practice during their first years?

4. What are the perceptions of pre-service, beginner, and advanced art teachers in Kuwait regarding what beginning art teachers should know and be able to do and how well they thought their education prepared them for their current position?

5. What are the pre-service, beginners, and advanced art teachers in Kuwait feelings towards the most influencing person during their teacher training?

\section{Supporting Question \#1: What are the perceptions of pre-service, beginner, and}




\section{advanced art teachers in Kuwait regarding the theoretical and practical training they received in their teacher education programs?}

As supported by the results of this study, pre-service art teachers felt more than adequately prepared to meet the needs of culturally diverse students by $M=2.1159$, $(n=69)$, whereas, in-service beginners art teachers felt adequately prepared by $M=2.5000$, $(n=124)$, and in-service advanced art teachers also felt adequately prepared by $M=2.5857$, $(n=140)$. Further, pre-service art teachers felt adequately prepared to meet the needs of the handicapped by $M=2.5507,(n=69)$. Conversely, in-service beginners art teachers felt less than adequately prepared by $M=3.3952$, $(n=124)$. By comparison, in-service advanced art teachers shared the same feeling with pre-service art teachers that they felt adequately prepared to meet the needs of the handicapped by $M=2.9714$, $(n=140)$.

Furthermore, pre-service art teachers felt more than adequately prepared to meet the needs of the gifted and talented students by $M=2.1739$, $(n=69)$, whereas, in-service beginners art teachers felt adequately prepared by $M=2.7016,(n=124)$, and in-service advanced art teachers felt adequately prepared by $M=2.7000,(n=140)$. Moreover, preservice art teachers felt more than adequately prepared to maintain control of student behavior by $M=2.0290,(n=69)$. Similarly, in-service beginners art teachers also felt more than adequately prepared $M=2.3145,(n=124)$. While in-service advanced art teachers felt adequately prepared to maintain control of student behavior $M=2.5214$, $(n=140)$. Most pre-service art teachers provided strong training in maintaining control of classroom management by $M=1.8986,(n=69)$. In comparison to in-service beginners art teachers, who felt more than adequately prepared by $M=2.1855,(n=124)$, and in-service advanced art teachers, who felt more than adequately prepared $M=2.4429,(n=140)$. Lastly, pre- 
service art teachers felt adequately prepared to use a variety of assessments to determine student progress by $M=2.5797$, $(n=69)$. Instead, in-service beginners art teachers felt less than adequately prepared $M=3.4113$, $(n=124)$. Indeed in-service advanced art teachers also felt less than adequately prepared to use a variety of assessments to determine student progress $M=3.0857,(n=140)$.

In short, participants in this study felt very well prepared to maintain control of classroom management, and certainly needs to be more prepared to meet the needs of the handicapped and to use a variety of assessments to determine student progress. As

reported by respondents, the program is successful in preparing them to meet the needs of the gifted, talented students, and to meet the needs of culturally diverse students.

Therefore, as reported by the respondents, art education teacher training program at the CBE had well prepared and trained these art teachers to maintain control of student behavior and to gain theoretical and practical training.

\section{Supporting Question \#2: What are the pre-service, beginner, and advanced art teachers in Kuwait feelings regarding how well they think their education prepared them for their current positions?}

In this study it is clear that pre-service art teachers felt well prepared to teach art in the first years of teaching $(44.9 \%, n=31)$, and in-service beginner art teachers also felt well prepared to teach art in the first years of teaching $(32.3 \%, n=40)$. However, inservice advanced art teachers did not felt that they were well prepared to teach art in the first years of teaching $(25.7 \%, n=36)$. In a like manner, pre-service art teachers $(31.9 \%$, $n=22)$, in-service beginner art teachers $(35.5 \%, n=44)$, and in-service advanced art 
teachers $(40.7 \%, n=57)$ reported that they were able to have enough time for preparation for teaching.

As supported by the finding of this study, pre-service art teachers agreed that their teacher training during the field experience course was very effective $(34.8 \%, n=24)$, and their teacher training needs to be improved $(342.0 \%, n=29)$. Just in the same way of the pre-service art teachers group, in-service beginner art teachers also agreed that their teacher training during the field experience course was very effective $(34.7 \%, n=41)$, and their teacher training needs to be improved $(34.7 \%, n=43)$. As well pre-service art teachers group and in-service beginner art teachers group, in-service advanced art teachers group also agreed that their teacher training during the field experience course was very effective $(32.9 \%, n=46)$, and their teacher training needs to be improved $(42.9 \%, n=60)$.

The result indicated that pre-service art teachers $(26.1 \%, n=18)$ and in-service advanced art teachers $(26.4 \%, n=37)$ agreed that they have adequate budget for their equipment and supplies. In contrast, in-service beginner art teachers did not agree that they have adequate budget for their equipment and supplies $(29.8 \%, n=37)$.

Finally, according to the participants in this study, pre-service $(31.9 \%, n=22)$, and in-service beginner $(32.3 \%, n=40)$, and advanced $(32.1 \%, n=45)$ art teachers strongly agreed to become an art teacher again, given the opportunity to start over. It is clear to see that all participants of this study are willing to become an art teacher again, given the opportunity to start over.

In short, pre-service and in-service beginner art teachers felt well prepared to teach art in the first years of teaching, whereas, in-service advanced art teachers did not 
feel that they were well prepared to teach art in the first years of teaching. Moreover, preservice and in-service art teachers agreed that their teacher training during the field experience course was very effective. Yet, their teacher training needs to be improved.

Moreover, pre-service art teachers and in-service advanced art teachers agreed that they have adequate budget for their equipment and supplies. In contrast, in-service beginner art teachers did not agree that they have adequate budget for their equipment and supplies. As reported by respondents, they are strongly agreed to become an art teacher again, given the opportunity to start over. Therefore, art education teacher training program at the $\mathrm{CBE}$ had well prepared art teachers for their current positions.

\section{Supporting Question \#3: What are the pre-service, beginner, and advanced art teachers in Kuwait feelings regarding the effectiveness of their field experience courses and how it prepared them for their teaching practice during their first years?}

This study examined the art education program in the State of Kuwait. The description of art education program revealed that required credit hours to obtain a degree in art education were 130 total semester hours during four academic years. Examining the number of hours required by the College of Basic Education revealed that more hours of study are dedicated to studio courses and skills than any of the other areas such as the field experience-training course.

For example, to major in art education, a student in Kuwait is required to complete 130 credits in art education. These required credit hours are distributed as follows: 30 credits for general education courses and elective courses, 69 credits for 
major requirement courses (Studio Art, Art Production, Aesthetics and Art Criticism) 11 credits for field training courses ( 9 credits for school field-training, 2 credits for a seminar course), 20 credits for minor courses in Interior Design (College of Basic Education, 2013 - Appendix N).

According to the participants in this study, pre-service art teachers agreed that the length of the field experience course was perfect $(42.0 \%, n=29)$. Similarly, in-service advanced art teachers agreed that the length of the field experience course was perfect $(42.1 \%, n=59)$. On the other hand, in-service beginner art teachers disagreed that the length of the field experience course was perfect $(29.8 \%, n=37)$.

Further as supported by the results of this study, pre-service art teachers showed equally results to have longer field experience courses before entering their first classroom. Some of the participants agreed $(30.4 \%, n=21)$, the other disagreed $(30.4 \%$, $n=21)$, while the rest divided between strongly agreed $(17.4 \%, n=12)$ and strongly disagreed $(10.1 \%, n=7)$. The last part responded as don't know by $(11.6 \%, n=8)$.

Furthermore, in-service beginner art teachers strongly agreed to have a longer field experience courses before entering their first classroom $(33.9 \%, n=42)$. Indeed, inservice advanced art teachers also agreed to have a longer field experience courses before entering their first classroom $(40.0 \%, n=56)$.

As a result, pre-service and in-service advanced art teachers agreed that the length of the field experience course was perfect. On the other hand, in-service beginner art teachers disagreed that the length of the field experience course was perfect. As reported by respondents, art teachers agreed to have a longer field experience courses before entering their first classroom. 
It was found that the art education program in the CBE in Kuwait has a strong training program but dictate fewer school field training courses comparing to art method courses such as studio coursework, or art history coursework, and education coursework. Based on the data from the survey responses, descriptions of art education courses and the review of the literature, these results indicate that the field experience courses were the most important part of the preparation for art teachers. Therefore, consideration for more classroom observation and longer internships as recommended by the responses of the participants in this study.

\section{Supporting Question \#4: What are the perceptions of pre-service, beginner, and advanced art teachers in Kuwait regarding what beginning art teachers should know and be able to do and how well they thought their education prepared them for their current position?}

Participants were asked to rank their perceptions of their preparedness to teach or perform 18 skills required by the College of Basic Education in Kuwait in order to obtain art education certification. They could indicate their preparedness on a five-point scale from very well prepared to poorly prepare. Ranked from lowest to highest means, the lowest mean is the more prepared they feel.

Through the data gathered from the respondents' perceptions of their preparedness to teach and perform the 18 skills, pre-service art teachers of CBE felt very well prepared to teach drawing, painting, art history, and maintain control of classroom management (Mean between 1.5 - 2 on the scale). They were also more than adequately prepared to teach art criticism, maintain control of student behavior, meet the needs of 
culturally diverse students, teach ceramics, meet the needs of the gifted and talented students, use technology in classroom, teach sculpture, and teach printmaking (Mean between $2-2.5$ on the scale). The respondents felt adequately prepared to teach fiber arts, meet the needs of the handicapped, use a variety of assessments to determine student progress, teach mixed media, teach graphic design, and teach computer applications (Mean between 2.5 - 3 on the scale).

Secondly, in-service beginners art teachers at MOE felt more than adequately prepared to teach drawing, painting, art history, maintain control of classroom management, teach art criticism, maintain control of student behavior, and meet the needs of culturally diverse students (Mean between $2-2.5$ on the scale). They were also adequately prepared to teach ceramics and to meet the needs of the gifted and talented students (Mean between 2.5 - 3 on the scale). The respondents felt less than adequately prepared to teach sculpture, use technology in classroom, teach printmaking, teach fiber arts, meet the needs of the handicapped, use a variety of assessments to determine student progress, and teach mixed media (Mean between $3-3.5$ on the scale). The respondents felt poorly prepared to teach graphic design and to teach computer applications (Mean between 3.5 - 4 on the scale).

Lastly, in-service advanced art teachers at MOE felt more than adequately prepared to teach drawing, painting, art history, maintain control of classroom management, and to teach art criticism (Mean between $2-2.5$ on the scale). They were also felt adequately prepared to maintain control of student behavior, meet the needs of culturally diverse students, teach ceramics, meet the needs of the gifted and talented students, use technology in classroom, teach sculpture, teach printmaking, teach fiber 
arts, and meet the needs of the handicapped (Mean between 2.5 - 3 on the scale). The respondents felt less than adequately prepared use a variety of assessments to determine student progress, teach mixed media, teach graphic design, and teach computer applications (Mean between $3-3.5$ on the scale).

The mean ratings for each skill across all the three groups indicated that these art teachers as a whole felt more than adequately prepared to teach drawing, painting, art history, and art criticism. Besides, these art teachers felt adequately prepared to teach ceramics, and less than adequately prepared to teach to teach sculpture, use technology in classroom, teach printmaking, teach fiber arts. Lastly they felt poorly prepared to teach mixed media, teach graphic design, and use computer applications.

Based on data of this study, it was concluded that art education training program at CBE provided strong training in drawing, painting, art history, and art criticism, ceramics, and a less training skills in mixed media, graphic design, printmaking, and fiber arts. In conclusion, according to the participants in this study, beginning art teachers in Kuwait believed their teacher education program was related to their teaching effectiveness.

\section{Supporting Question \#5: What are the pre-service, beginners, and advanced art teachers in Kuwait feelings towards the most influencing person during their teacher training?}

Participants were asked to respond to whether they were able to contact with other art teachers in either in the same school or in other schools. Pre-service art teachers responded toward being able to contact with other art teachers in the same school (33.3\%, 
$n=23$ ), whereas uncertain or don't know opinions about being able to contact with other art teachers in the other school were reported at $(30.4 \%, n=21)$. Similarly, in-service beginner art teachers have positive attitude toward being able to contact with other art teachers in the same school $(29.8 \%, n=37)$. Consequently, positive feelings were also reported toward being able to contact with other art teachers in the other school $(33.9 \%, n$ =42). Admittedly, that the more experience art teaches have the more knowledge they will gain about other schools and others art teaches. As well as in-service beginner art teachers, in-service advanced art teachers have positive attitude toward being able to contact with other art teachers in the same school $(30.0 \%, n=42)$. And, positive feelings were also reported toward being able to contact with other art teachers in the other school $(38.6 \%, n=54)$.

Secondly, respondents were asked to rate the most influential person during their teacher training. Different influential people were reported. Pre-service art teachers reported that their classmates and other art teachers were the most influential people during their teacher training by $44.9 \%(n=31)$ of the respondents. In-service beginner art teachers reported that their supervisor was the most influential person during their teacher training by $36.3 \%(n=45)$ of the respondents. Lastly, in-service advanced art teachers reported that their art education professor was the most influential person during their teacher training by $36.4 \% \%(\mathrm{n}=51)$ of the respondents. In final consideration, participants in this study indicated that there was a connection between the influence of classmates and other art teachers, supervisors, and art education professors and effective preparation for teaching. 


\section{Guiding Research Question: How do pre-service, beginner, and advanced art teachers in Kuwait describe and evaluate their teacher preparation program?}

On the whole of the purpose of this study, pre-service, beginning, and advanced art teachers in Kuwait described and evaluated their teacher preparation and training program. According to the findings of this study, the most valuable preparation for teaching was being able to practice and perform art studio skills and to gain experience through the impact of the field experience courses or internships.

\section{Discussion, Implications, and Suggestions}

In related to the five research questions, this discussion focused on field experience courses, observation levels, influential people during teacher training, and assigning more art studio classes or skills.

According to the literature review, results, and findings, and according to the perceptions of the pre-service and in-service Kuwaiti art teachers, this study offered two suggestions:

(1) According to the finding of this study, pre-service and in-service beginner art teachers felt well prepared to teach art in the first years of teaching. Likewise as stated in Al-Najar study, it was found that the first and second year art teachers felt well prepared and successful in all the three areas (Al-Najar, 2001). Yet, in-service advanced art teachers did not feel that they were well prepared to teach art in the first years of 
teaching. Indeed, as stated by Harrell, "Teachers clearly expressed a need for more practical information on what to do and how to do it" (Harrell, 2007, p.168).

An important shift of teachers' perceptions regarding their feeling of art teacher preparation occurred. Pre-service and in-service beginner art teachers felt well prepared to teach art in the first years of teaching, whereas, in-service advanced art teachers did not feel that they were well prepared to teach art in the first years of teaching. Art teachers have shifted their perceptions from very well prepared during their first year of their teaching to adequately prepared or poorly prepared. The shifting in their perception was because of their experience in teaching.

As stated in the results, the majority of art teachers agreed to have longer field experience and training courses. In a recent study, Milbrandt indicated that teaching experience is a powerful influence on art education students (2006). The more experience they have, the more they feel confident and well prepared to teach. According to Harrell, "to gain more practical skills, a need for more observation and practice in the classroom through longer internships," is important (Harrell, 2007, p. 169). The more time they spent in the field experience, the more prepared they would feel.

A previous case study by Darling-Hammond and MacDonald indicated that field experience courses and pre-service programs should take from 12 to 24 months to complete, depending on how students organize their course taking. The study concluded that every program should include a full academic year of student teaching under close supervision from university supervisors who also work as course instructors and advisors (Darling-Hammond \& MacDonald, 2000). It is also suggested that field experience 
courses should offer more options on school observation. This includes: elementary, middle and high school observations. As Harrell stated, "Beginning teachers are not guaranteed employment in the grade levels where they intern. If they do accept teaching positions at grade levels where they have had no prior experience, they will find themselves at a further disadvantage during their first years of teaching" (Harrell, 2007, p.172). Pre-service art teachers should have a chance to observe and practice teaching in different level of classrooms (elementary, middle, and high school classrooms). It was also recommended that the program could be improved with the addition of more studio courses.

A chart describe the shift in the differences between art teachers' perceptions toward how well they felt prepared to teach in their first year of their teaching.

Table 29

\begin{tabular}{|l|l|l|l|l|l|l|l|l|}
\hline$\#$ & \multicolumn{2}{|l|}{$\begin{array}{l}\text { I feel well prepared to teach art in the first } \\
\text { years of teaching }\end{array}$} & $\mathrm{SD}$ & $\mathrm{D}$ & $\mathrm{DK}$ & $\mathrm{A}$ & $\mathrm{SA}$ & Total \\
\hline 1 & Pre-Service Art Teachers & $\mathrm{N}$ & 7 & 14 & 5 & 31 & 12 & 69 \\
\cline { 3 - 10 } & $\%$ & 10.1 & 20.3 & 7.2 & 44.9 & 17.4 & 100 \\
\hline 2 & In-Service Beginner Art Teachers & $\mathrm{N}$ & 27 & 22 & 5 & 40 & 30 & 124 \\
\cline { 3 - 9 } & & $\%$ & 21.8 & 17.7 & 4.0 & 32.3 & 24.2 & 100 \\
\hline \multirow{2}{*}{3} & In-Service Advanced Art Teachers & $\mathrm{N}$ & 30 & 36 & 17 & 35 & 22 & 140 \\
\cline { 3 - 9 } & $\%$ & 21.4 & 25.7 & 21.1 & 25.0 & 15.7 & 100 \\
\hline
\end{tabular}

The majority of pre-service art teachers agreed that their field experience course length was perfect $(42.0 \%, n=29)$. Yet, equally positive and negative feelings were reported toward the willing to have a longer field experience courses before entering their first classroom $(30.4 \%, n=21)$. On the other hand, the majority of in-service beginner art teachers did not agree that the length of the field experience course was perfect $(29.8 \%, n$ 
$=37)$. Yet, they strongly agreed to have longer field experience courses before entering their first classroom $(33.9 \%, n=42)$. Finally, the majority of in-service advanced art teachers disagreed that the length of the field experience course was perfect $(42.1 \%, n=$ 59). Besides they agreed to have longer field experience courses before entering their first classroom $(40.0 \%, n=56)$.

(2) Recommendations for Further Research

This study suggested doing more research on art teacher preparation programs and how those preparation programs affect pre-service teaching practice. Moreover, this study recommended investigating the different perceptions between male and female art teachers. It is also advised to use different data methods such as observation, interviews, and case studies to find and explore more factors that may affect the effectiveness of the teacher training programs. Further research is needed to investigate more factors that affect the preparation programs, and to address and identify more skills in the art curriculum (internet technology, computers application, etc).

This study also recommended the investigation on the collaboration between universities and public schools, and to build connections between the universities faculties and art teachers. This improves art teachers' skills during their field experience courses, and has a long-term effect on their art education, teaching and learning (Milbrandt, 2006). Art teachers who are willing to collaborate with others may be more knowledgeable about other teaching styles, values, and cultures (Milbrandt, 2006).

Harrell suggested that there should be more collaboration between universities and schools to bridge the gap between what is taught at the university and translated into 
practice (2007). Literature in the field of education also suggested for collaboration between pre-service teachers and teacher educators (Hanes and Schiller, 1994; Henry, 2007; Milbrandt, 2006). Additionally, researchers such as Eisner and Zimmerman have implied for collaboration between universities and public schools (Eisner, 1972; Zimmerman, 1994).

Harrell stated in her study that "collaboration is important and beneficial in building communication, sharing responsibility, and processing all that occurs within classrooms and schools" (2007, p. 12). Hutchens determined that there should be a strong relationship between art education faculty and university faculty, especially among preservice art teachers (1997). This relation will build the skills needed for art teachers and will support pre-service teachers' professional growth. It is important to make sure that pre-service teachers are applying what they learned in their universities to their schools. In summary, there should be a link between universities, pre-service teachers, and schools.

Finally this study recommended investigating the role of the student teacher supervisor. Supervising teachers have a strong impact on art education students. They help to fill the gap between pre-service art education students and their schools. They are there not only to evaluate, but also to provide emotional and educational support to their pre-service students. Their role in mentoring and coaching is important on pre-service art education students.

According to Ryan "teacher educators should follow their new teachers into their entry-level jobs to help them resolve the problems they face as beginning teachers" (As cited in Harrell, 2007). Milbrandt said, "Topics of mentoring began to merge with topics 
of professional development and research" (2006). The art teacher supervisor during the student's teaching experience has a strong influence on the teacher's professional development (Milbrandt, 2006). According to Susi, "The supervising intern teachers typically are chosen based on three factors: years of experience, knowledge of the subject matter, and instructional skills that are assumed to be superior to those of the intern" (As cited in Harrell, 2007).

Linda Darling-Hammond and John Bransford stated in their book, Preparing Teachers for a Changing World, that teacher training is necessary before entering schools:

If improvement in education is the goal, it is not enough to prepare good teachers and send them out to schools. If teachers are to be effective, they must work in setting where they can use what they know-where, for example, they can come to know students and families well; work with other teachers to provide a coherent, well-grounded curriculum; evaluate and guide student progress using information rich assessments; and use texts and materials that support thoughtful learning (Hammond and Bransford, 2005, p. 4).

The suggestions in which Hammond and Bransford offered are important for every teacher institutions, colleges, and universities. Even though seeking quality of teacher education and preparing good teachers are our goal, there are other important areas we need to be more concern about. These areas are: good relationship between teachers and their students, collaboration with other teachers in the field, knowledge and skills about the materials and teaching, and professional development. 


\section{Limitation of the Study}

The research study was limited to Kuwaiti art teachers who have completed their classroom observation. These are students in their last year at College of Basic Education $\mathrm{CBE}$, those who are teaching in the first of their second year at the Ministry of Education in Kuwait MOE, or those who are ready to teach in the beginning of their fourth year at the Ministry of Education in Kuwait MOE. This study was narrowed to include three groups of participants (pre-service, in-service beginner, and in-service advanced art teachers) and was focused only on art teacher's perceptions toward their preparations' efficiency.

\section{Summary of Conclusions}

This study viewed, examined, and investigated the perceptions of pre-service, beginner, and advanced art teachers about the effectiveness of the teacher education program in the State of Kuwait. This study has offered some specific recommendations based on the finding of the data. It was suggested to have more art studio skills and classes, longer field experience courses and internships, more classroom observations at all teaching levels, and more collaboration between the college and the public schools. This study clarified the influence of classmates and other art teachers, supervisor, and art education professor and the effective preparation for teaching. 


\section{Appendix A}

The IRB Approval from West Virginia University 


\section{W. WestlirginiaUniversity. \\ Office of Research Integrity and Compliance}

\section{Acknowledgement Letter Exempt Initial Protocol Review}

To

From

Approval Period

Subject

Protocol Tracking

Title
Joy Saab

WVU Office of Research Integrity and Compliance

09/30/2013 Expiration Date 09/29/2016

Acknowledgement Letter Exempt Initial Protocol Review

1308083431

Perceptions and attitudes of the effectiveness of art education teachers preparation program in Kuwait

The above-referenced study was reviewed by the West Virginia University Institutional Review Board IRB and was granted exemption in accordance with $45 \mathrm{CFR} 46.101$.

- This research study was granted an exemption because the Research involves educational tests, survey procedures, interview procedures or observation of public behavior and (i) information obtained is recorded in such a manner that human subjects cannot be identified, directly or through identifiers linked to the subjects; and (ii) any disclosure of the human subjects responses outside the research could not reasonably place the subjects at risk of criminal or civil liability or be damaging to the subjects financial standing, employability, or reputation [45 CFR 46.101(2)]. All exemptions are only good for three years. If this research extends more than three years beyond the approved date, then the researcher will have to request another exemption. The following documents have been acknowledged for use in this study and are available in the WVU+kc system:

Documents for use in this study have been acknowledged and validated and are available in the WVUkc system in the Notes and Attachments section of your protocol.

If you have any questions, please contact the IRB at 3042937073.

Thank you.

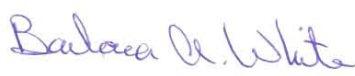

Board Designee Barbara White 
Letter Sent By Barbara White on 09/30/2013 at 09:29:54-04:00

Once you begin your human subject research, the following regulations apply:

1. Any modifications to the study protocol must be reviewed and acknowledged by the IRB prior to implementation.

2. You may not use a modified form until it has been acknowledged by the IRB. 


\section{Appendix B}

Survey Questionnaire for the Pre-Service Art Teachers at the College of Basic Education in Kuwait 


\section{SURVEY QUESTIONNAIRE FOR PRE-SERVICE ART TEACHERS AT THE COLLEGE OF BASIC EDUCATION IN KUWAIT}

Instructions: Please read each statement carefully. Check $(\sqrt{ })$ the response that best shows your opinion.

Part 1: Demographic Information:

1. Gender:

Male $\square \quad$ Female $\square$

2. Nationality: Kuwaiti $\square \quad$ Non- Kuwaiti $\square$

3. Age:

$$
18-22 \square \quad 23-27 \square \quad 28-32 \square \quad 33+\square
$$

Part 2: Perceptions \& Training Experiences:

Instructions: Please read each statement carefully. Check $(\sqrt{ })$ the response that best indicates your opinion.

\begin{tabular}{|l|l|l|l|l|l|}
\hline $\begin{array}{l}\text { How well prepared did } \\
\text { you feel to: }\end{array}$ & $\begin{array}{l}\text { Very } \\
\text { Well } \\
\text { Prepared } \\
1\end{array}$ & $\begin{array}{l}\text { More Than } \\
\text { Adequately } \\
\text { Prepared } \\
2\end{array}$ & $\begin{array}{l}\text { Adequately } \\
\text { Prepared }\end{array}$ & $\begin{array}{l}\text { Less Than } \\
\text { Adequately } \\
\text { Prepared } \\
4\end{array}$ & $\begin{array}{l}\text { Poorly } \\
\text { Prepared }\end{array}$ \\
\hline 4. Teach drawing. & & & & 5 & \\
\hline 5. Teach painting. & & & & & \\
\hline 6. Teach sculpture. & & & & & \\
\hline 7. Teach printmaking. & & & & & \\
\hline 8. Teach ceramics. & & & & & \\
\hline 9. Teach fiber arts. & & & & & \\
\hline 10. Teach mixed media. & & & & & \\
\hline 11. Teach graphic design. & & & & & \\
\hline $\begin{array}{l}\text { 12. Teach computer } \\
\text { applications. }\end{array}$ & & & & & \\
\hline 13. Teach art history. & & & & & \\
\hline 14. Teach art criticism. & & & & & \\
\hline $\begin{array}{l}\text { 15. Meet the needs of } \\
\text { culturally diverse } \\
\text { students. }\end{array}$ & & & & & \\
\hline $\begin{array}{l}\text { 16. Meet the needs of the } \\
\text { handicapped. }\end{array}$ & & & & & \\
\hline $\begin{array}{l}\text { 17. Meet the needs of the } \\
\text { gifted and talented } \\
\text { students. }\end{array}$ & & & & & \\
\hline $\begin{array}{l}\text { 18. Maintain control of } \\
\text { student behavior. }\end{array}$ & & & & & \\
\hline
\end{tabular}




\begin{tabular}{|l|l|l|l|l|l|}
\hline $\begin{array}{l}\text { How well prepared did } \\
\text { you feel to: }\end{array}$ & $\begin{array}{l}\text { Very } \\
\text { Well } \\
\text { Prepared } \\
1\end{array}$ & $\begin{array}{l}\text { More Than } \\
\text { Adequately } \\
\text { Prepared } \\
2\end{array}$ & $\begin{array}{l}\text { Adequately } \\
\text { Prepared }\end{array}$ & $\begin{array}{l}\text { Less Than } \\
\text { Adequately } \\
\text { Prepared } \\
4\end{array}$ & $\begin{array}{l}\text { Poorly } \\
\text { Prepared }\end{array}$ \\
\hline $\begin{array}{l}\text { 19. Maintain control of } \\
\text { classroom management. }\end{array}$ & & & & 5 \\
\hline $\begin{array}{l}\text { 20. Use technology in } \\
\text { classroom }\end{array}$ & & & & & \\
\hline $\begin{array}{l}\text { 21. Use a variety of } \\
\text { assessments to determine } \\
\text { student progress. }\end{array}$ & & & & & \\
\hline
\end{tabular}

Part 3: Attitudes:

Instructions: Please read each statement carefully. Check $(\sqrt{ })$ the response that best shows your attitudes regarding your art-training program.

\begin{tabular}{|l|l|l|l|l|}
\hline SD & D & DK & A & SA \\
\hline $\begin{array}{l}\text { Strongly } \\
\text { Disagree }\end{array}$ & Disagree & Don't Know & Agree & Strongly Agree \\
\hline
\end{tabular}

\begin{tabular}{|c|c|c|c|c|c|c|}
\hline \# & Statement & SD & $\mathrm{D}$ & DK & A & SA \\
\hline 22 & $\begin{array}{l}\text { I feel well prepared to teach art in the first years of } \\
\text { teaching. }\end{array}$ & & & & & \\
\hline 23 & I have contact with other art teachers in the same school. & & & & & \\
\hline 24 & I have contact with other art teachers in other schools. & & & & & \\
\hline 25 & I have adequate budget for equipment and supplies. & & & & & \\
\hline 26 & I have enough time for preparation for teaching. & & & & & \\
\hline 27 & $\begin{array}{l}\text { My supervisor was the most influential person during my } \\
\text { teacher training. }\end{array}$ & & & & & \\
\hline 28 & $\begin{array}{l}\text { My classmates and other art teachers were the most } \\
\text { influential people during my teacher training. }\end{array}$ & & & & & \\
\hline 29 & $\begin{array}{l}\text { My art education professor was the most influential person } \\
\text { during my teacher training. }\end{array}$ & & & & & \\
\hline 30 & $\begin{array}{l}\text { My teacher training during the field experience course was } \\
\text { very effective. }\end{array}$ & & & & & \\
\hline 31 & My teacher training needs to be improved. & & & & & \\
\hline 32 & My teacher training does not need to be changed. & & & & & \\
\hline 33 & My field experience course length was perfect. & & & & & \\
\hline 34 & $\begin{array}{l}\text { I would like to have a longer field experience courses } \\
\text { before entering my first classroom. }\end{array}$ & & & & & \\
\hline 35 & $\begin{array}{l}\text { I would become an art teacher again, given the opportunity } \\
\text { to start over. }\end{array}$ & & & & & \\
\hline
\end{tabular}




\section{Appendix C}

Survey Questionnaire for In-Service Art Teachers at the Ministry of Education in Kuwait 


\section{SURVEY QUESTIONNAIRE FOR IN-SERVICE ART TEACHERS AT THE PUBLIC SCHOOLS IN KUWAIT}

Instructions: Please read each statement carefully. Check $(\sqrt{ })$ the response that best shows your opinion.

Part 1: Demographic Information:

1. Gender:

Male $\square \quad$ Female $\square$

2. Nationality: Kuwaiti $\square \quad$ Non- Kuwaiti $\square$

3. Age:

$$
18-22 \square \quad 23-27 \square \quad 28-32 \square \quad 33+\square
$$

4. What level do you teach?

Elementary $\square \quad$ Middle School $\square \quad$ High School $\square$

5. Number of Years Teaching Art

One Year $\square$ Two years $\square$ Three Years $\square$ Four Years $\square$ More than Four Years $\square$

6. What university/College did you attend?

College of Basic if Education $\square$ Kuwait University $\square$ others $\square$........... None $\square$

Part 2: Perceptions \& Training Experiences:

Instructions: Please read each statement carefully. Check $(\sqrt{ })$ the response that best indicates your opinion.

\begin{tabular}{|l|l|l|l|l|l|}
\hline $\begin{array}{l}\text { How well prepared did } \\
\text { you feel to: }\end{array}$ & $\begin{array}{l}\text { Very } \\
\text { Well } \\
\text { Prepared } \\
1\end{array}$ & $\begin{array}{l}\text { More Than } \\
\text { Adequately } \\
\text { Prepared } \\
2\end{array}$ & $\begin{array}{l}\text { Adequately } \\
\text { Prepared }\end{array}$ & $\begin{array}{l}\text { Less Than } \\
\text { Adequately } \\
\text { Prepared } \\
4\end{array}$ & $\begin{array}{l}\text { Poorly } \\
\text { Prepared }\end{array}$ \\
\hline 7. Teach drawing. & & & & & 5 \\
\hline 8. Teach painting. & & & & & \\
\hline 9. Teach sculpture. & & & & & \\
\hline 10. Teach printmaking. & & & & & \\
\hline 11. Teach ceramics. & & & & & \\
\hline 12. Teach fiber arts. & & & & & \\
\hline 13. Teach mixed media. & & & & & \\
\hline
\end{tabular}




\begin{tabular}{|l|l|l|l|l|l|}
\hline 14. Teach graphic design. & & & & \\
\hline $\begin{array}{l}\text { How well prepared did } \\
\text { you feel to: }\end{array}$ & $\begin{array}{l}\text { Very } \\
\text { Well } \\
\text { Prepared } \\
1\end{array}$ & $\begin{array}{l}\text { More Than } \\
\text { Adequately } \\
\text { Prepared } \\
2\end{array}$ & $\begin{array}{l}\text { Adequately } \\
\text { Prepared }\end{array}$ & $\begin{array}{l}\text { Less Than } \\
\text { Adequately } \\
\text { Prepared } \\
4\end{array}$ & $\begin{array}{l}\text { Poorly } \\
\text { Prepared }\end{array}$ \\
\hline $\begin{array}{l}\text { 15. Teach computer } \\
\text { applications. }\end{array}$ & & & & 5 \\
\hline 16. Teach art history. & & & & & \\
\hline 17. Teach art criticism. & & & & & \\
\hline $\begin{array}{l}\text { 18. Meet the needs of } \\
\text { culturally diverse } \\
\text { students. }\end{array}$ & & & & & \\
\hline $\begin{array}{l}\text { 19. Meet the needs of the } \\
\text { handicapped. }\end{array}$ & & & & & \\
\hline $\begin{array}{l}\text { 20. Meet the needs of the } \\
\text { gifted and talented } \\
\text { students. }\end{array}$ & & & & & \\
\hline $\begin{array}{l}\text { 21. Maintain control of } \\
\text { student behavior. }\end{array}$ & & & & & \\
\hline $\begin{array}{l}\text { 22. Maintain control of } \\
\text { classroom management. }\end{array}$ & & & & & \\
\hline $\begin{array}{l}\text { 23. Use technology in } \\
\text { classroom }\end{array}$ & & & & & \\
\hline $\begin{array}{l}\text { 24. Use a variety of } \\
\text { assessments to determine } \\
\text { student progress. }\end{array}$ & & & & & \\
\hline
\end{tabular}

Part 3: Attitudes:

Instructions: Please read each statement carefully. Check $(\sqrt{ })$ the response that best shows your attitudes regarding your art-training program.

\begin{tabular}{|l|l|l|l|l|}
\hline SD & D & DK & A & SA \\
\hline $\begin{array}{l}\text { Strongly } \\
\text { Disagree }\end{array}$ & Disagree & Don't Know & Agree & Strongly Agree \\
\hline
\end{tabular}

\begin{tabular}{|l|l|l|l|l|l|l|}
\hline$\#$ & Statement & SD & D & DK & A & SA \\
\hline 25 & $\begin{array}{l}\text { I feel well prepared to teach art in the first years of } \\
\text { teaching. }\end{array}$ & & & & \\
\hline 26 & I have contact with other art teachers in the same school. & & & & & \\
\hline 27 & I have contact with other art teachers in other schools. & & & & & \\
\hline 28 & I have adequate budget for equipment and supplies. & & & & \\
\hline
\end{tabular}




\begin{tabular}{|c|c|c|c|c|c|c|}
\hline 29 & I have enough time for preparation for teaching. & & & & & \\
\hline \# & Statement & SD & $\mathrm{D}$ & DK & A & SA \\
\hline 30 & $\begin{array}{l}\text { My supervisor was the most influential person during my } \\
\text { teacher training. }\end{array}$ & & & & & \\
\hline 31 & $\begin{array}{l}\text { My classmates and other art teachers were the most } \\
\text { influential people during my teacher training. }\end{array}$ & & & & & \\
\hline 32 & $\begin{array}{l}\text { My art education professor was the most influential person } \\
\text { during my teacher training. }\end{array}$ & & & & & \\
\hline 33 & $\begin{array}{l}\text { My teacher training during the field experience course was } \\
\text { very effective. }\end{array}$ & & & & & \\
\hline 34 & My teacher training needs to be improved. & & & & & \\
\hline 35 & My teacher training does not need to be changed. & & & & & \\
\hline 36 & My field experience course length was perfect. & & & & & \\
\hline 37 & $\begin{array}{l}\text { I would like to have a longer field experience courses } \\
\text { before entering my first classroom. }\end{array}$ & & & & & \\
\hline 38 & $\begin{array}{l}\text { I would become an art teacher again, given the opportunity } \\
\text { to start over. }\end{array}$ & & & & & \\
\hline
\end{tabular}




\section{Appendix D}

Cover letter Form for both the Pre-Service Art Teachers at the CBE and In-Service Art Teachers at the MOE in Kuwait 


\section{Dear Participant,}

This letter is a request for you to take part in a research project to collect information regarding perceptions towards the art teacher education and teaching experiences from College of Basic Education for my dissertation research. This project is being conducted by Ghadeer Alhaddad, in Kuwait with supervision of Dr. Joy Saab, a professor in the College of Education at West Virginia University, for a Doctor's Degree in Education. Your participation in this project is greatly appreciated and will take approximately 10 minutes to fill out the attached questionnaire. Your involvement in this project will be kept as confidential as legally possible. All data will be reported in the aggregate. You must be 18 years of age or older to participate. I will not ask any information that should lead back to your identity as a participant. Your participation is completely voluntary. You may skip any question that you do not wish to answer and you may discontinue at any time. I hope that you will participate in this research project, as it could be beneficial for providing information that will lead to increases knowledge regarding the teaching experiences of beginning teachers. This Knowledge can assist in the increased effectiveness of art teacher preparation program in Kuwait and will support improving the preparation of pre-service art teachers in the College of Basic Education (CBE) in the State of Kuwait.

Thank you very much for your time. Should you have any questions about this letter or the research project, please feel free to contact Ghadeer Alhaddad at (724) 7778855 (email-galhadda@mix.wvu.edu) or Dr. Joy Faini Saab, an Art Education faculty advisor who supervises this research project, at (304-293-3778) (emailjoy.saab@mail.wvu.edu) for answers to questions about this research or my rights.

Thank you for your time and help with this project.

Sincerely,

Ghadeer Alhaddad

West Virginia University

College of education and human services

Curriculum and instruction

Art Education galhadda@mix.wvu.edu 


\section{Appendix E}

Permission letter to the College of Basic Education in Kuwait And the Approval letter from the CBE 
Dear Sir/Madam,

I am a doctoral student majoring in Curriculum and Instruction in Art Education at West Virginia University, and I am eager to collect information regarding perceptions towards the teacher education and teaching experiences from College of Basic Education for my dissertation research. The result of this investigation will support the improvement of the preparation of pre-service art teachers in the College of Basic Education. The purpose of this research study is (1) to view, examine, and investigate the perceptions and of pre-service, beginner, and advanced art teachers about the effectiveness of the art teacher education program in the State of Kuwait and (2) to offer suggestions for program improvement and the design of local curricular guidelines for the future of the art teacher programs.

Therefore, please accept this letter as a request for permission to distribute my survey questionnaire in the art classes at the Department of Art Education in the College of Basic Education.

Respectfully,

Ghadeer Alhaddad

West Virginia University

College of education and human services

Curriculum and instruction

Art Education

galhadda@mix.wvu.edu 
THE PUBLIC AUTHORITY FOR APPLIED EDUCATION \& TRAINING.

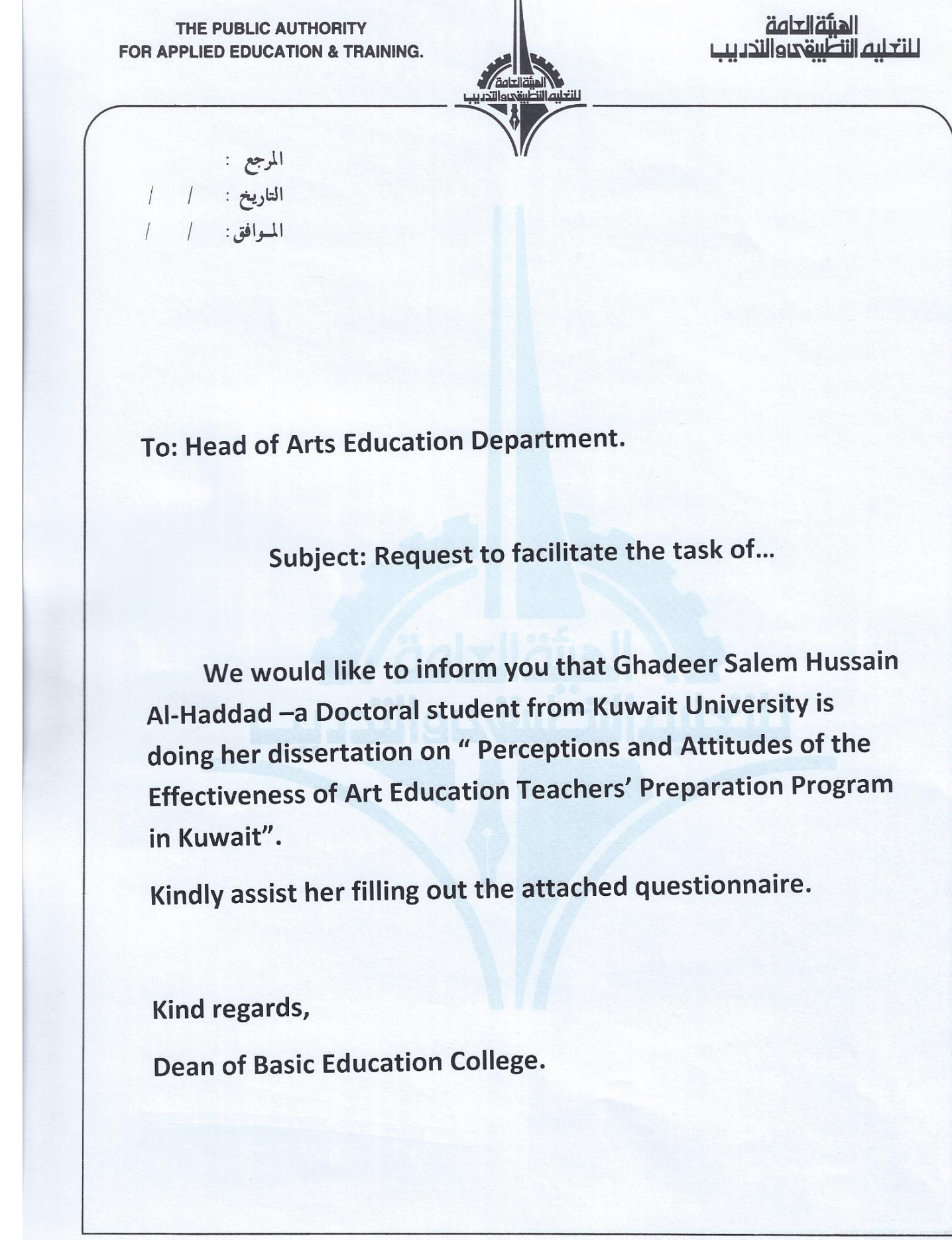


Appendix F

Arabic Version of the Permission letter to the College of Basic Education in Kuwait and the Approval letter from the CBE 


$$
\text { السادة الأعزاءه }
$$

أنا طالبة في الدكتراة، تخصص مناهج وتعليم في الثربية الفنبة في جامعة ويبت فرجينيا، وأتمنى الحصول على معلومات فيما يتعلق بالمفاهيم والميول تجاه تعليم المدرس وخبرات التدريس من كلية التربية الأساسية في رسالتي البحثية. نتيجة هذا البحث ستاعم عملية تحسين أداء مدرسي التربية الفنية قبل الخدمة في كلية الثربية الأساسية. الغرض من هذه الدراسة البحثية هو 1) مراجعة، فحص وبحث مفاهيم

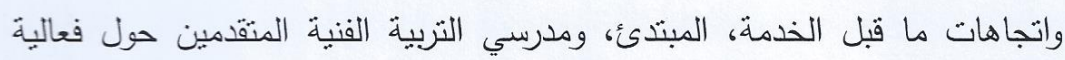
برنامج تعليم المدرس في دولة الكويت و 2) ثقديم اقتراحات لتصسين البرنامج وتصميم إرشادات مناهج محلية لمسنقبل براهج ددرسي التربية الفنبة.

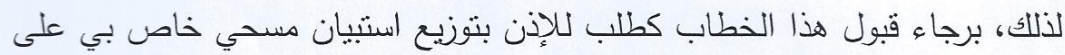
فصول التربية الفنية في قنم التربية الفنية في كلية التربية الأساسية.

$$
\begin{aligned}
& \text { مع التحية، } \\
& \text { غدير الحداد } \\
& \text { جامعة ويست فرجينيا } \\
& \text { كلبة التزبية والخدمات الإنسانية } \\
& \text { مناهج وتربية } \\
& \text { تربية فنبة }
\end{aligned}
$$

galhadda@mix.wvu.edu

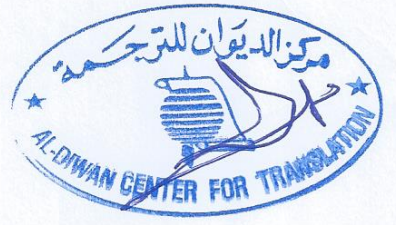




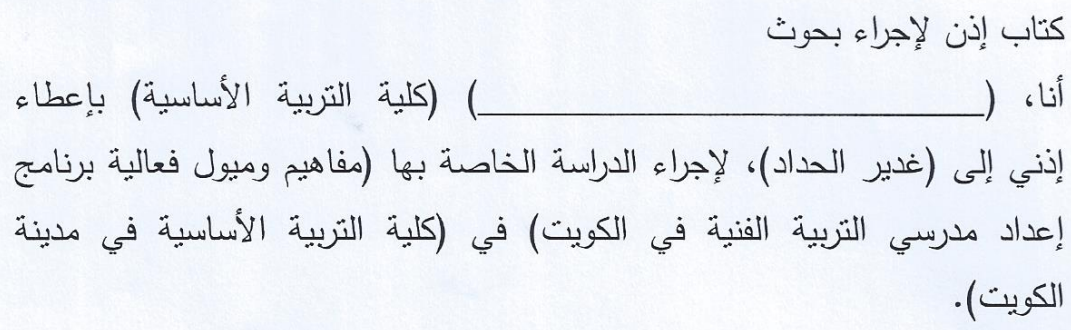

$$
\text { توقيع مدير الموقع مدير الموقع مطبوعًا }
$$

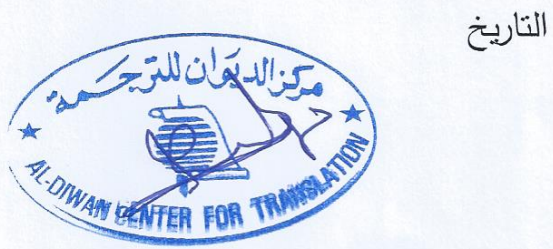




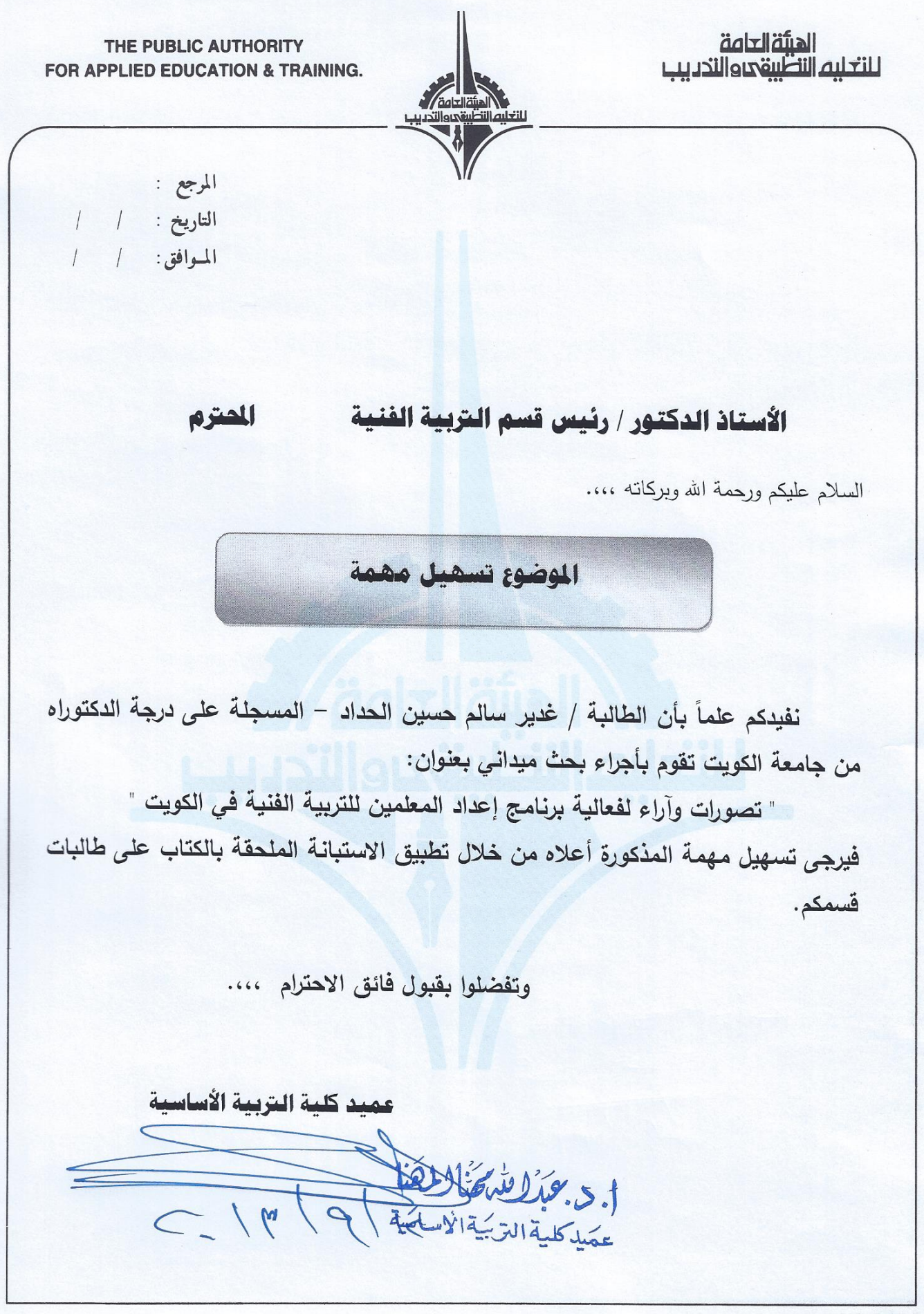


الخمبس

\section{الأستاذ الدكتمر / عميد كلية التزبية الأساسية}

السيلام عليكم ورحمة الله ويركاته ،6، 6.

\section{الموضوع تسهيل همهمة الطالبة / غدير سالم هسين المداد}

$$
\begin{aligned}
& \text { أفيادم علما بأنني أنا الطالبة / غدير سالم حسين العداد - المسجلة على درجة }
\end{aligned}
$$

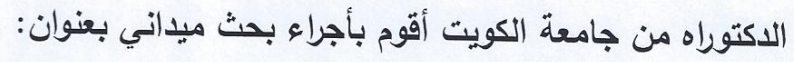

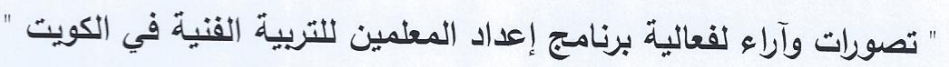

لذا أرجو التكرم بتسهيل مهيتي المذكورة أعلاه من خلال تطبيث الاستبانة الملحقة

$$
\text { بالكتاب على طالبات قسم التربية الفنية في كلية التربية الأساسية. }
$$

وتفضلوا بقبول فائق الاحترام ،6، .

$$
\text { المر فقات: نسخة من الاستبانة }
$$

\section{مقدهـ: الطالبة / غدير سالم حسين العداد}

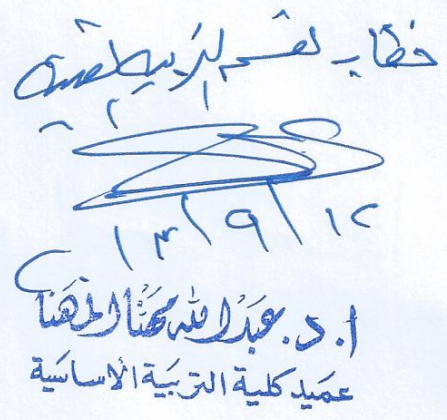




\section{Appendix G}

Permission letter to the Ministry of Education in Kuwait and the Approval letter from the MOE 
Dear Sir/Madam,

I am a doctoral student majoring in Curriculum and Instruction in Art Education at West Virginia University, and I am eager to collect information regarding perceptions towards the teacher education and teaching experiences from College of Basic Education for my dissertation research. The result of this investigation will support the improvement of the preparation of pre-service art teachers in the College of Basic Education. The purpose of this research study is (1) to view, examine, and investigate the perceptions of pre-service, beginner, and advanced art teachers about the effectiveness of the teacher education program in the State of Kuwait and (3) to offer suggestions for program improvement and the design of local curricular guidelines for the future of the art teacher programs.

Therefore, please accept this letter as a request for permission to distribute my survey questionnaire at the Department of Art Education in the Ministry of Education.

Respectfully,

Ghadeer Alhaddad

West Virginia University

College of education and human services

Curriculum and instruction

Art Education

galhadda@mix.wvu.edu 


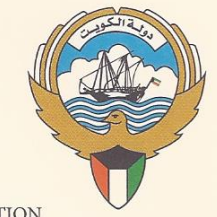

$$
\text { وزارة التربية }
$$

قطاع البحوث التريوية والمناهيج

EDUCATIONAL RESEARCH \& DEVELOPMENT ADMINISRATION

\begin{tabular}{|c|c|}
\hline 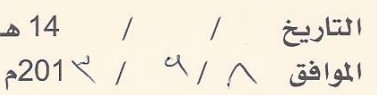 & الرقرف: وت/ / \\
\hline
\end{tabular}

\section{Letter of Permission to Conduct Research at Government schools}

\section{Head of Hawalli Governorate}

To whom it may concern,

I, (The Director of Educational Research Department) give my permission for ( Ghadeer AlHaddad) to conduct her questionnaire related to (Perceptions and Attitudes of the Effectiveness of Art Education Teachers Preparation Program In Kuwait) at (The Government Schools in Hawally and capital districts in Kuwait).

Ebtesam A. Al Hay

Director of Educational Research Department, Ministry of Education, Kuwait.
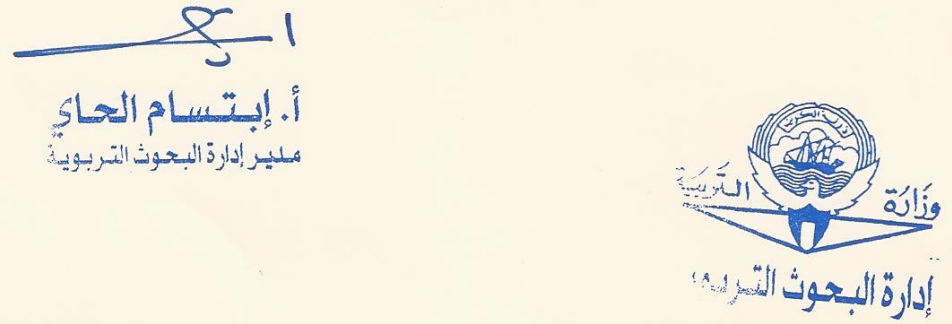

Al _Qurain -Block (1) - Street No (1)

القرين - قطعة (1) - (1) - شارع رقمى (1) - (1) Tel.. 25417942 - Fax: 25417694 -25417943

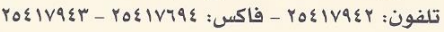
Email: behooth@hotmail.com 
0085698

MINISTRY OF EDUCATION

Educational Research and

Curricula Sector

EDUCATIONAL RESEARCH \& DEVELOPMENT ADMINISRATION

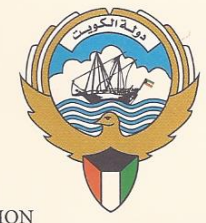

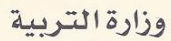

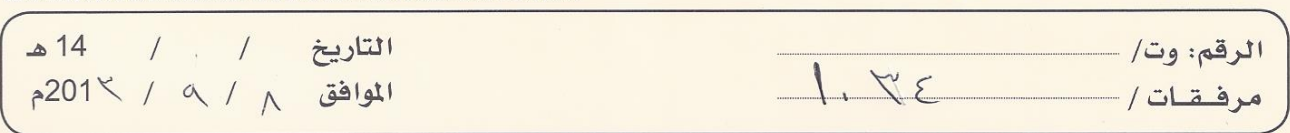

\section{Letter of Permission to Conduct Research at Government schools}

\section{Head of Al.Aasma Governorate}

To whom it may concern,

I, (The Director of Educational Research Department) give my permission for ( Ghadeer AlHaddad) to conduct her questionnaire related to (Perceptions and Attitudes of the Effectiveness of Art Education Teachers Preparation Program In Kuwait) at (The Government Schools in Hawally and capital districts in Kuwait).

Ebtesam A. Al Hay

Director of Educational Research Department, Ministry of Education, Kuwait.
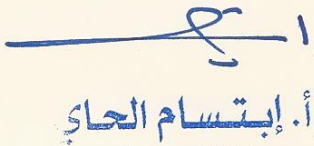

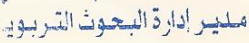

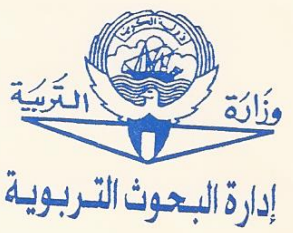

Al _Qurain -Block (1) - Street No (1)

القرين - قطعة (1) - شارع رقم (1) - (1)

Tel.. 25417942 - Fax: 25417694 -25417943

Email: behooth@hotmail.com 


\section{Appendix $\mathrm{H}$}

Arabic Version of the Permission letter to the Ministry of Education in Kuwait and the Approval letter from the MOE 


$$
\text { السادة الأعزاء، }
$$

أنا طالبة في الدكتوراة، تخصص مناهج وتعليم في الثربية الفنية في جامعة ويست فرجينيا، وأتنىى الحصول على معلومات فيما يتعلق بالمفاهيم والميول تجاه تعليم لتيم

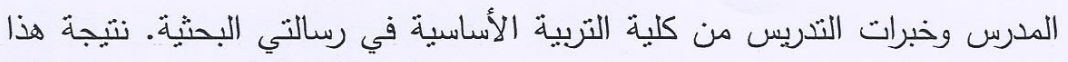
البحث ستدعم عملية تحسين أداء مدرسي التربية الفنية قبل الخدمة في كلية التربية الأساسية. الغرض من هذه الدراسة البحثية هو 1) مراجعة، فحص وبحث مفاهيم واتجاهات ما قبل الخدمة، المبندئ، ومدرسي التربية الفنية المثقدمين حول فعالية برنامج تعليم المدرس في دولة الكويت، و 2) ثقديم اقتراحات لتحسين البرنامج وتصميم إرشادات مناهج محلية لمستقبل براهج ددرسي التربية الفنبة.

لذللك، برجاء قبول هذا الخطاب كطلب للإذن بتوزيع استبيان مسحي خاص بي في قسم التربية الفنية في وزارة التربية.

$$
\begin{aligned}
& \text { همع التحبة، } \\
& \text { غدير الحداد } \\
& \text { جامعنة ويست فرجينيا } \\
& \text { كلية التربية والخدمات الإنسانية } \\
& \text { مناهج وتربية }
\end{aligned}
$$
galhadda@,mix.wvu.edu

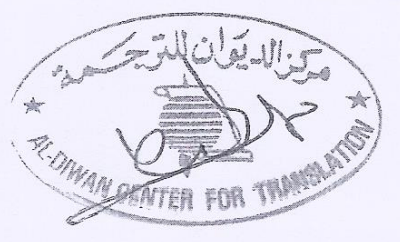


MINISTRY OF EDUCATION

Educational Research and

Curricula Sector

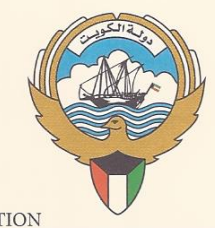

$$
\text { وزارة التتربية }
$$

قطاع البحوث التربوية والمناهج

EDUCATIONAL RESEARCH \& DEVELOPMENT ADMINISRATION

إدارة البحوث والتطوير انتربوي

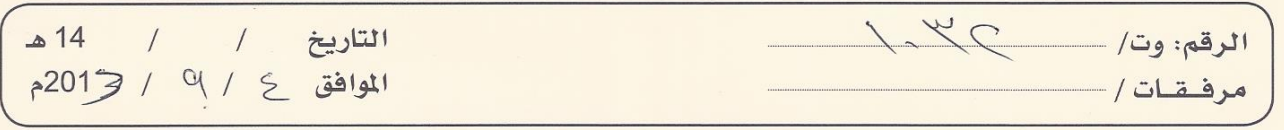

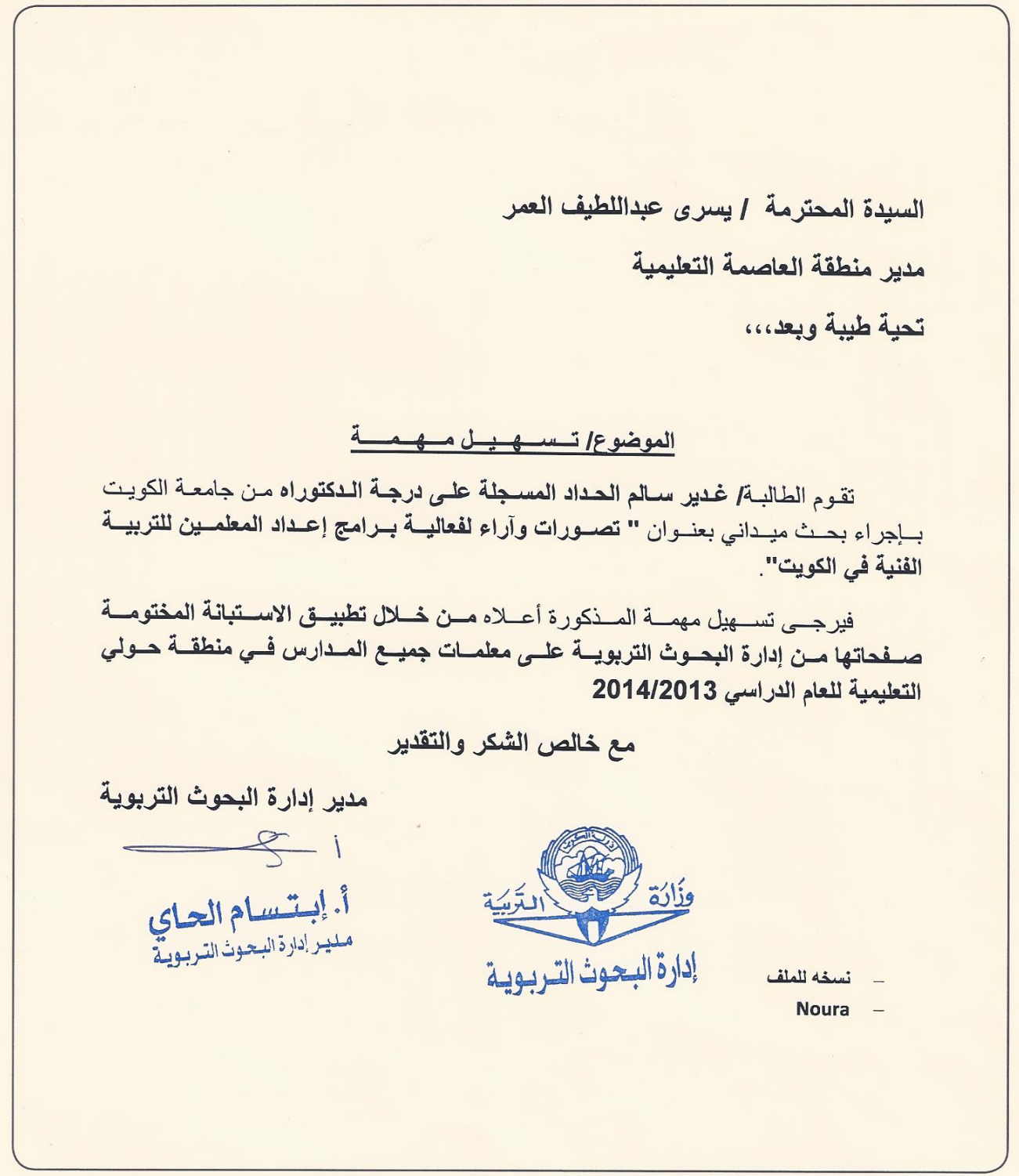

Al _Qurain _Block (1) - Street No (1)

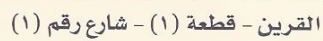

Tel:. 25417942 - Fax: 25417694 -25417943

تلفون: ro\&IV9\& - ro\&IV79 \&

Email: behooth@hotmail.com 
MINISTRY OF EDUCATION

Educational Research and

Curricula Sector

EDUCATIONAL RESEARCH \& DEVELOPMENT ADMINISRATION

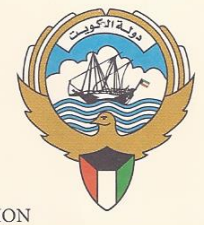

$$
\text { وزارة التتربية }
$$

قطاع البحوث التريوية والمناهـج

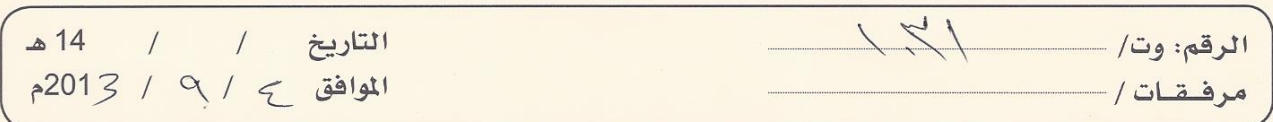

السبد المحترم / عبدالله هلال الحربي

مدير منطقة حولي التعليمية

تصية طيبة وبعد،6، 6

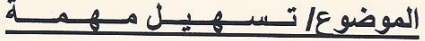

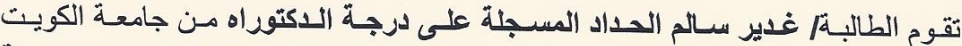

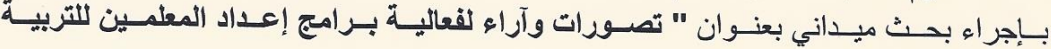

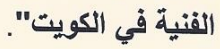

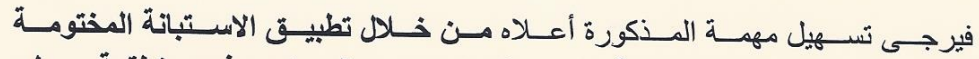

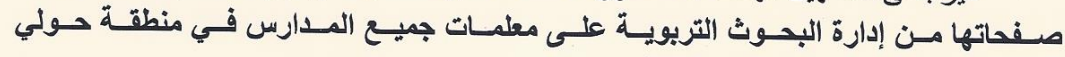

التعليمية للعام الدراسي $2014 / 2013$

$$
\text { مع خالص الشَكر والتقدير }
$$

مدير إدارة البحوث التربوية
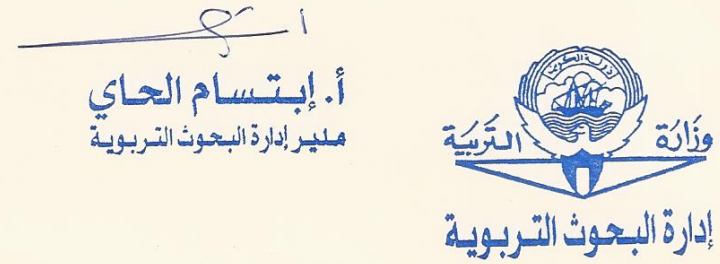

نسخه للملف

Noura

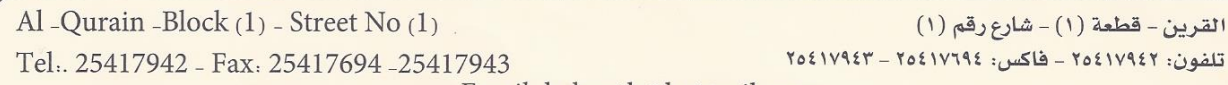
Email: behooth@hotmail.com 


\section{Appendix I}

Arabic Version of the Survey Questionnaire for the Pre-Service Art Teachers 


$$
\begin{aligned}
& \text { استبيان مسحي لهدرسي التربية الفنية قبل الخدمة في كلبة التربية الأساسية في } \\
& \text { الكويت } \\
& \text { توجيهات: برجاء قراءة المستتد بعناية، ضع دائرة صغيرة جوار الإجابة التي تمثل } \\
& \text { رأيكا. } \\
& \text { الجزء 1: المعلومات الديموغرافية }
\end{aligned}
$$

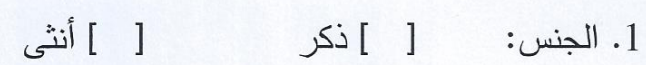

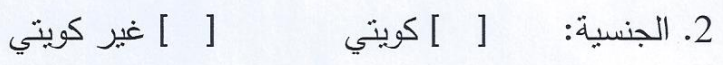

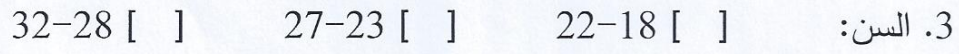

$$
\begin{aligned}
& 33+[\quad]
\end{aligned}
$$$$
\text { الجزء 2: الدفاهيم والخبرات التدرييية: }
$$$$
\text { توجيهات: برجاء قراءة المستند بعناية، ضع دائرة صغيرة جوار الإجابة التي ثمثل }
$$

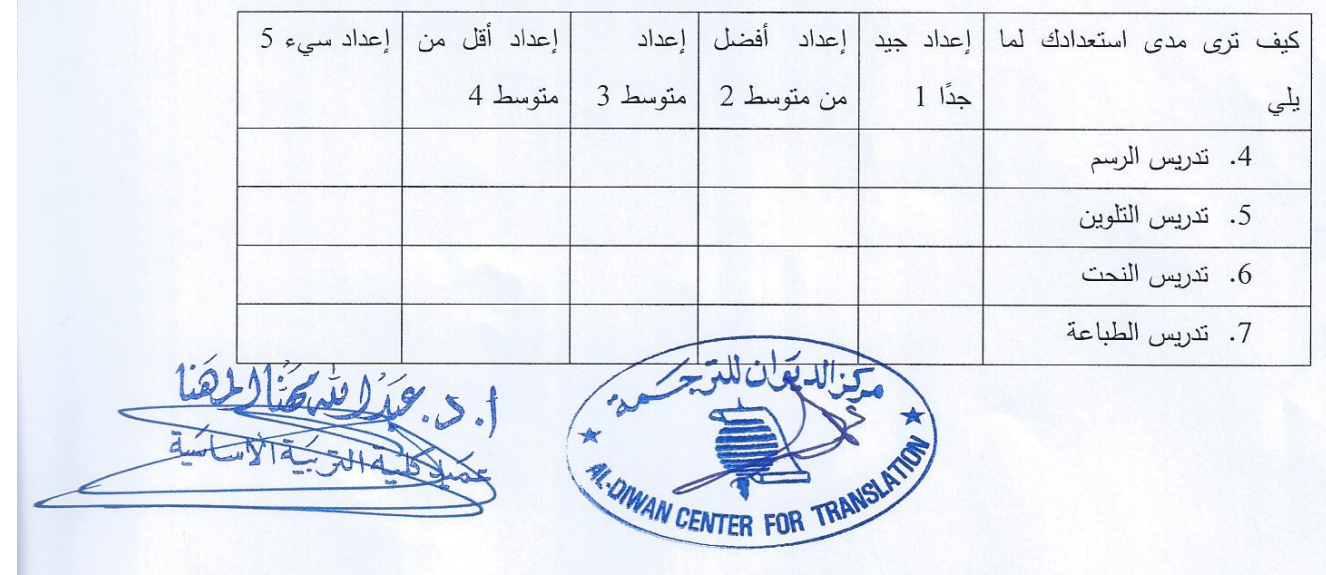




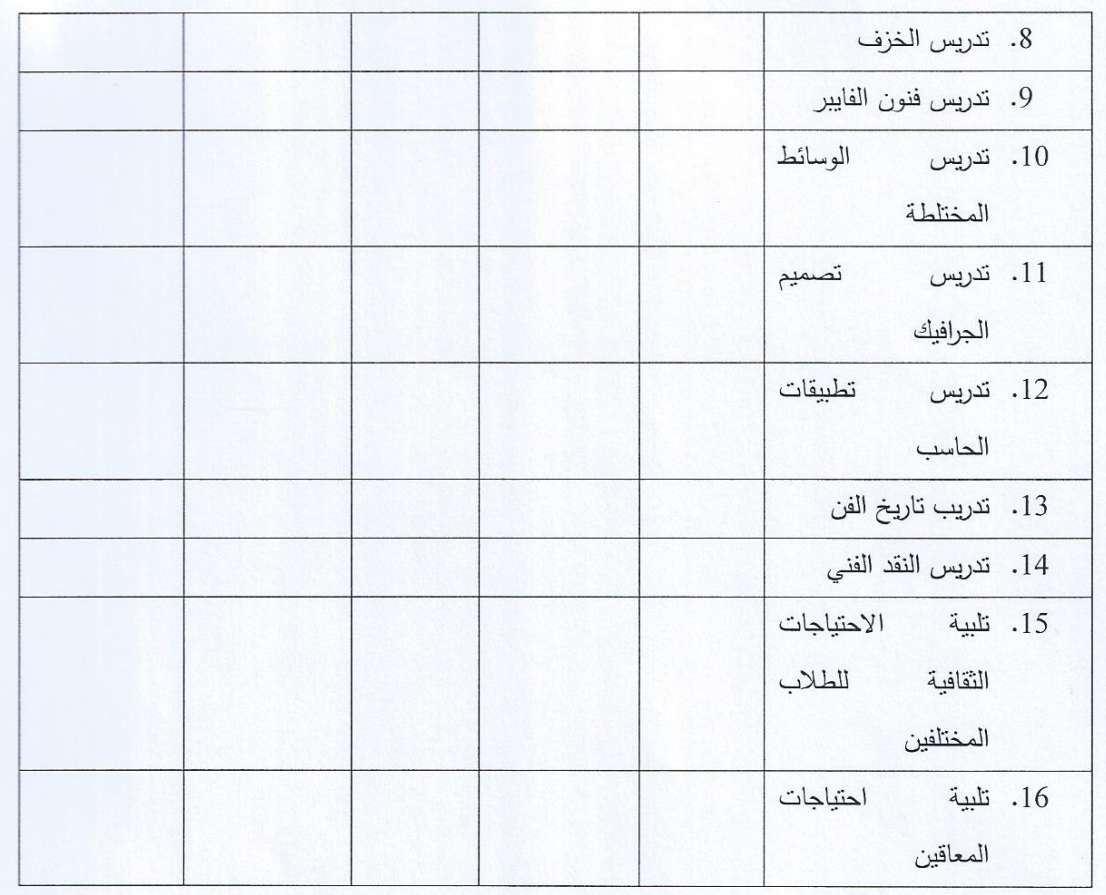

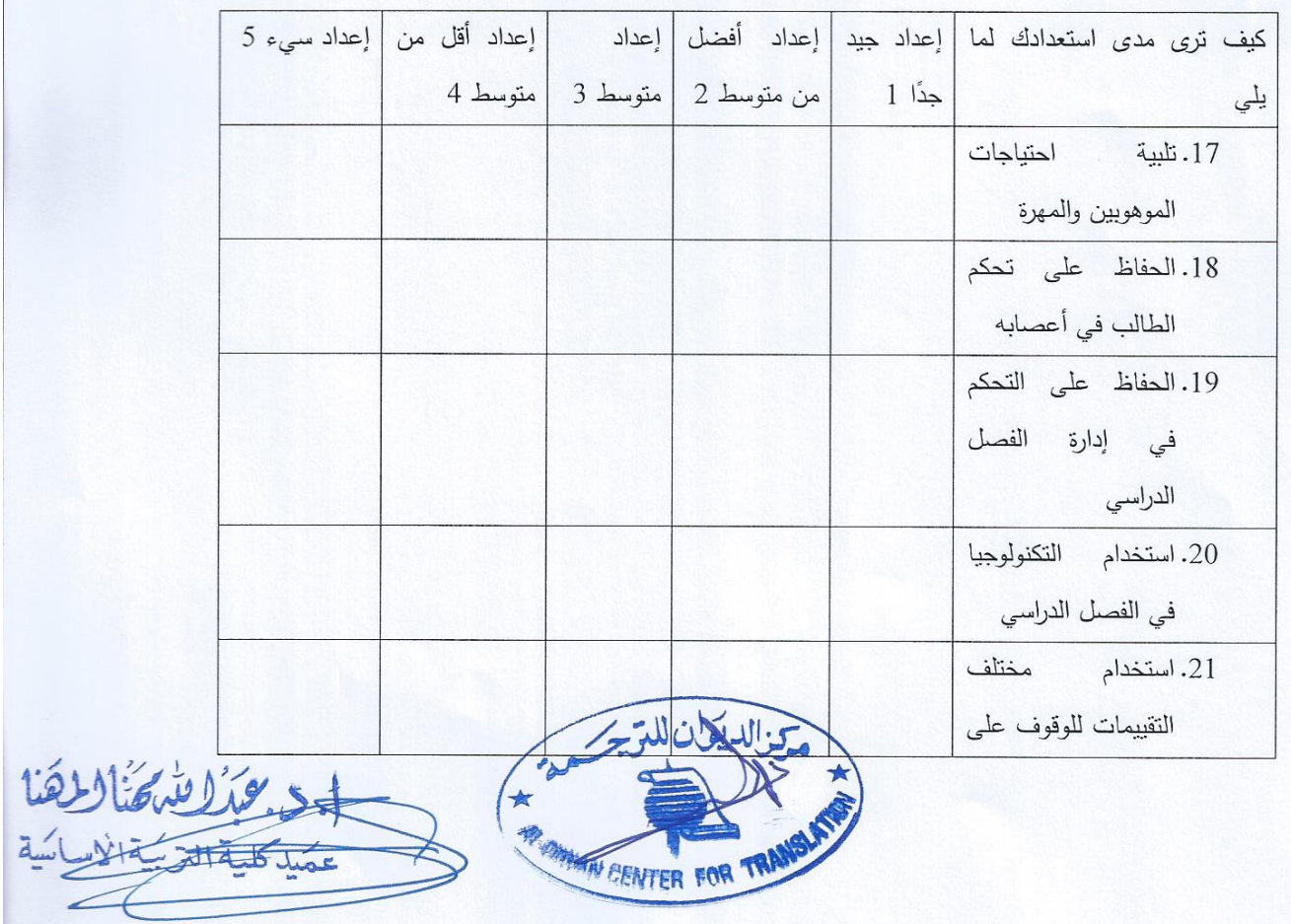




\begin{tabular}{|c|c|c|c|c|}
\hline & & & \multicolumn{2}{|c|}{ تقدم الطلاب } \\
\hline & & & \multicolumn{2}{|r|}{ لجزء 3: الميول } \\
\hline SA & A & DK & D & SD \\
\hline أوافق بشدة & أوافق & لا أعرف & لا أوافق & لا أوافق بشدة \\
\hline
\end{tabular}

\begin{tabular}{|l|l|l|r|r|r|}
\hline SA & A & DK & D & SD & \\
\hline
\end{tabular}




\begin{tabular}{|c|c|c|c|c|c|c|}
\hline & & & & & تدريب التدريس الخاص بي خلص برنامج الخبرة & .30 \\
\hline \multirow[t]{6}{*}{ SA } & A & DK & D & SD & البيان & \# \\
\hline & & & & & احتباجات تدريب التدريس الخاصة بي تحسنت & .31 \\
\hline & & & & & تدريب التدريس الخاص بي لم تتخير & .32 \\
\hline & & & & & طول برنامج الخبرة الميدانية الخاص بي أصبح ممنازًا & .33 \\
\hline & & & & & 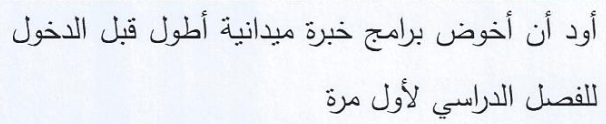 & .34 \\
\hline & & & & & 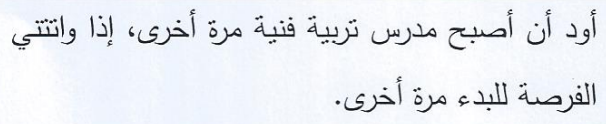 & .35 \\
\hline
\end{tabular}

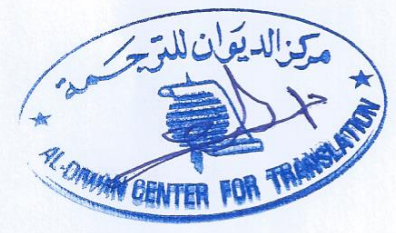




\section{Appendix $\mathbf{J}$}

Arabic Version of the Survey Questionnaire for the In-Service Art Teachers 


$$
\begin{aligned}
& \text { استبيان مسحي لمدرسي التزبية الفنية في الخدمة في ددارس التعليم العام في وزارة } \\
& \text { التربية في الكوبيت }
\end{aligned}
$$

توجيهات: برجاء قراءة المستند بعناية، ضع دائزة صغيرة جوار الإجابة التي تنلل

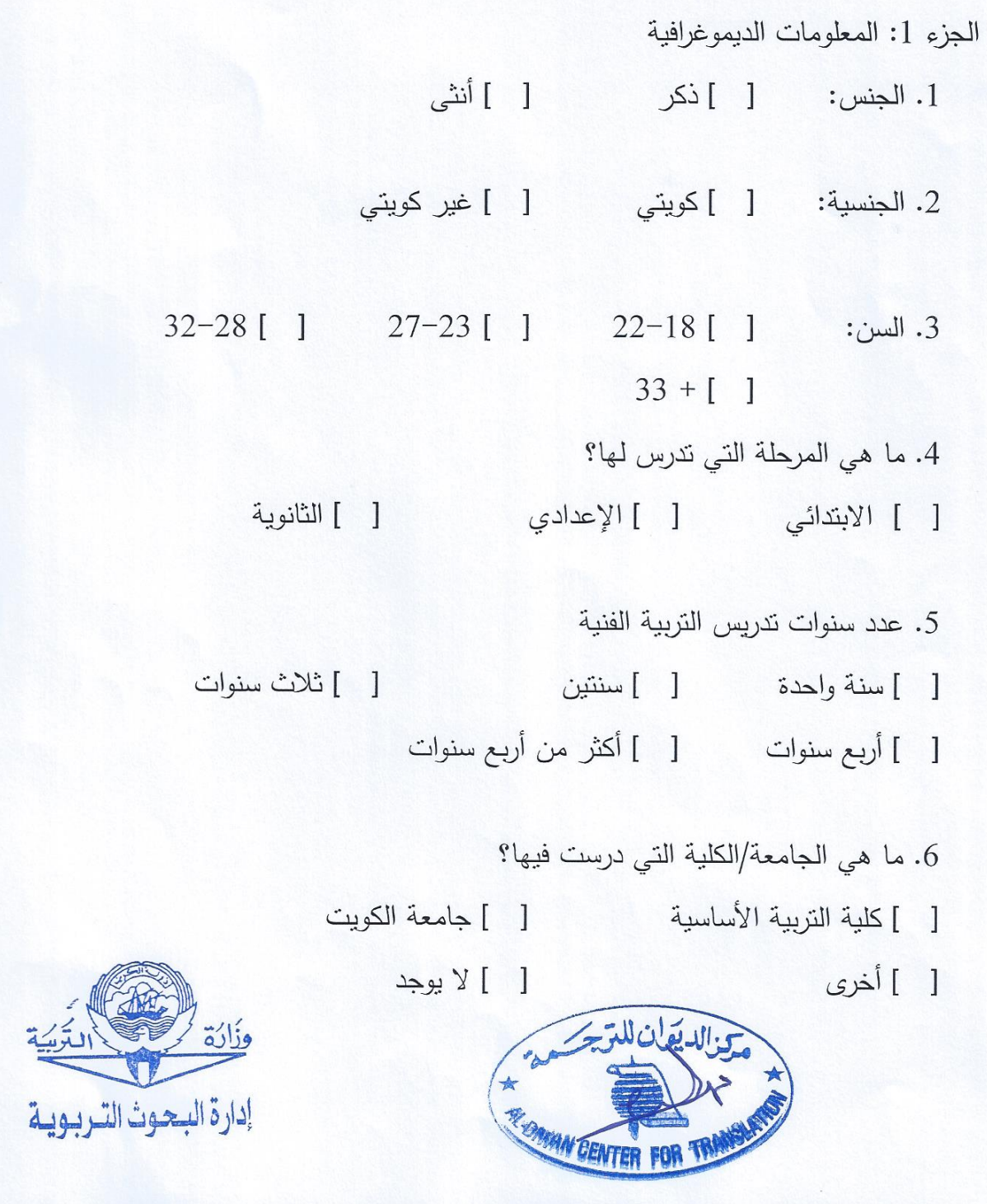


الجزء 2: الدفاهيم والخبرات التدربيية:

توجيهات: برجاء قراءة المستند بعناية، ضع دائرة صغيرة جوار الإجابة التي ثمثل

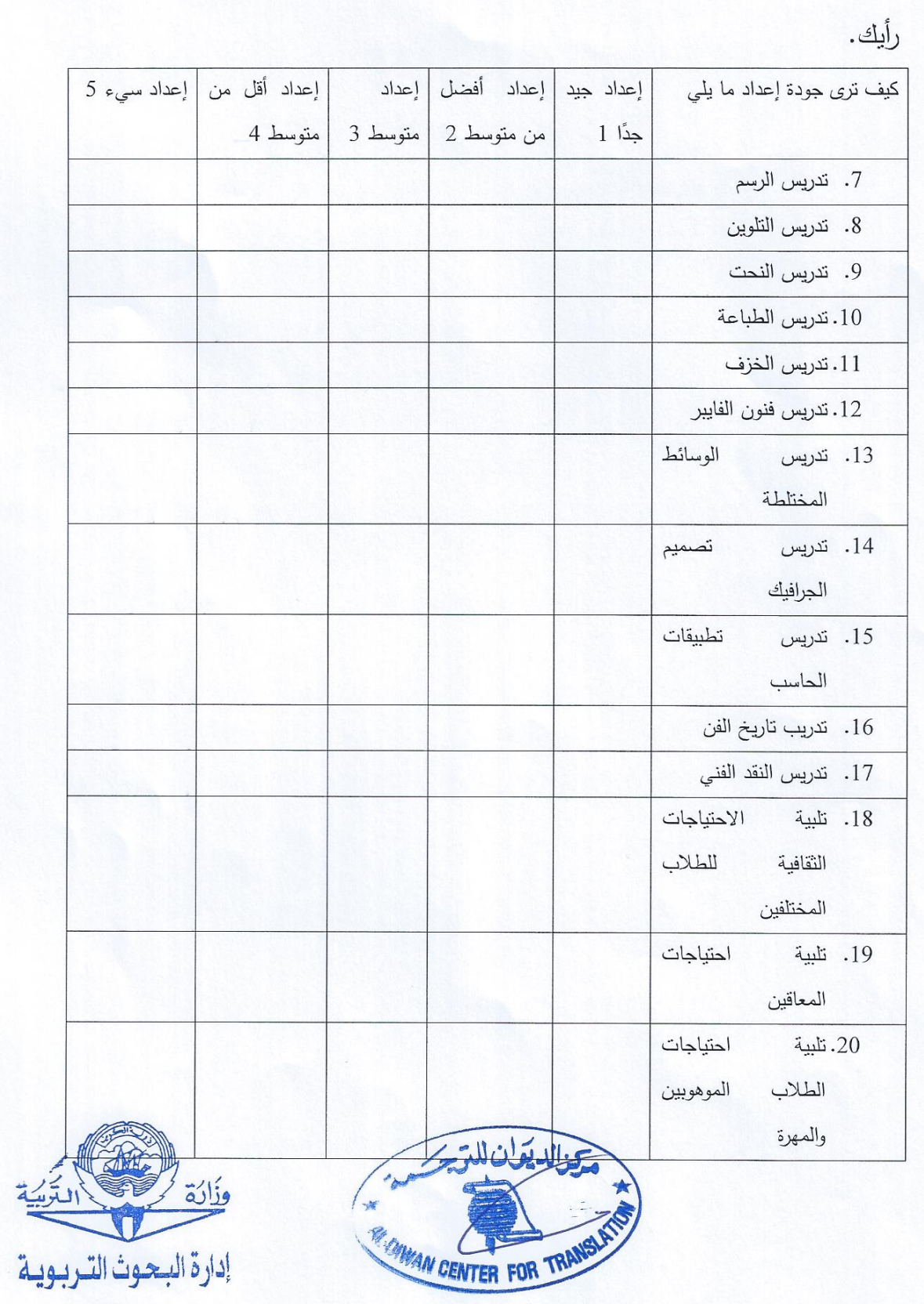




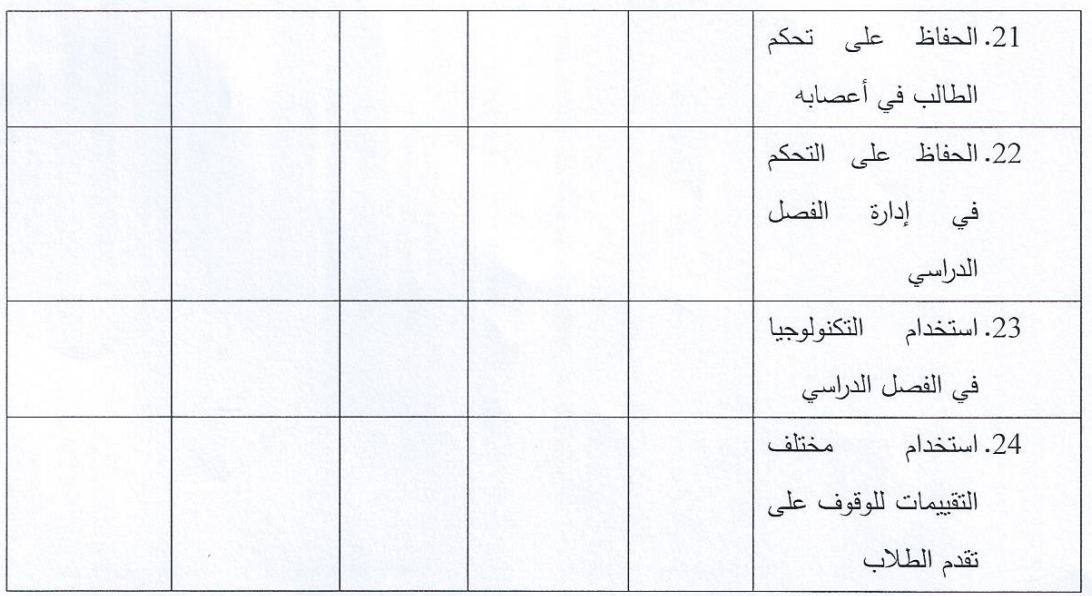

$$
\text { الجزء 3: الميول }
$$

توجيهات: برجاء قراءة المستتد بعناية، ضع دائرة صغيرة جوار الإجابة التي تمثلك ميولك فيما بتعلق بيرنامج التدريب الفني الخاص بك.

\begin{tabular}{|c|c|c|c|c|}
\hline SA & A & DK & $\mathrm{D}$ & $\mathrm{SD}$ \\
\hline أوافق بشدذ & أوافق & لا أعرف & لا أوافق & لا أوافق بشدة \\
\hline
\end{tabular}

\begin{tabular}{|c|c|c|c|c|c|c|}
\hline SA & A & DK & $\mathrm{D}$ & SD & البيان & $\#$ \\
\hline & & & & & 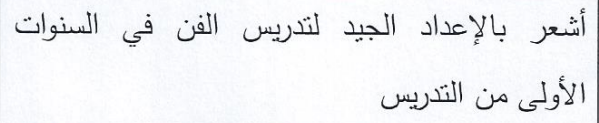 & .25 \\
\hline & & & & & قالمدرسة بالاتصال بمدرسي تربية فنية آخرين في نفس & .26 \\
\hline & & & & & قالمدرسة بالاتصال بمدرسي تربية فنية آخرين في نفس & .27 \\
\hline & & & & & لدي ميزانية مناسبة للمعدات والموارد & .28 \\
\hline & & & & & لادية الوقت الكافي للإعداد للتدريس & .29 \\
\hline
\end{tabular}




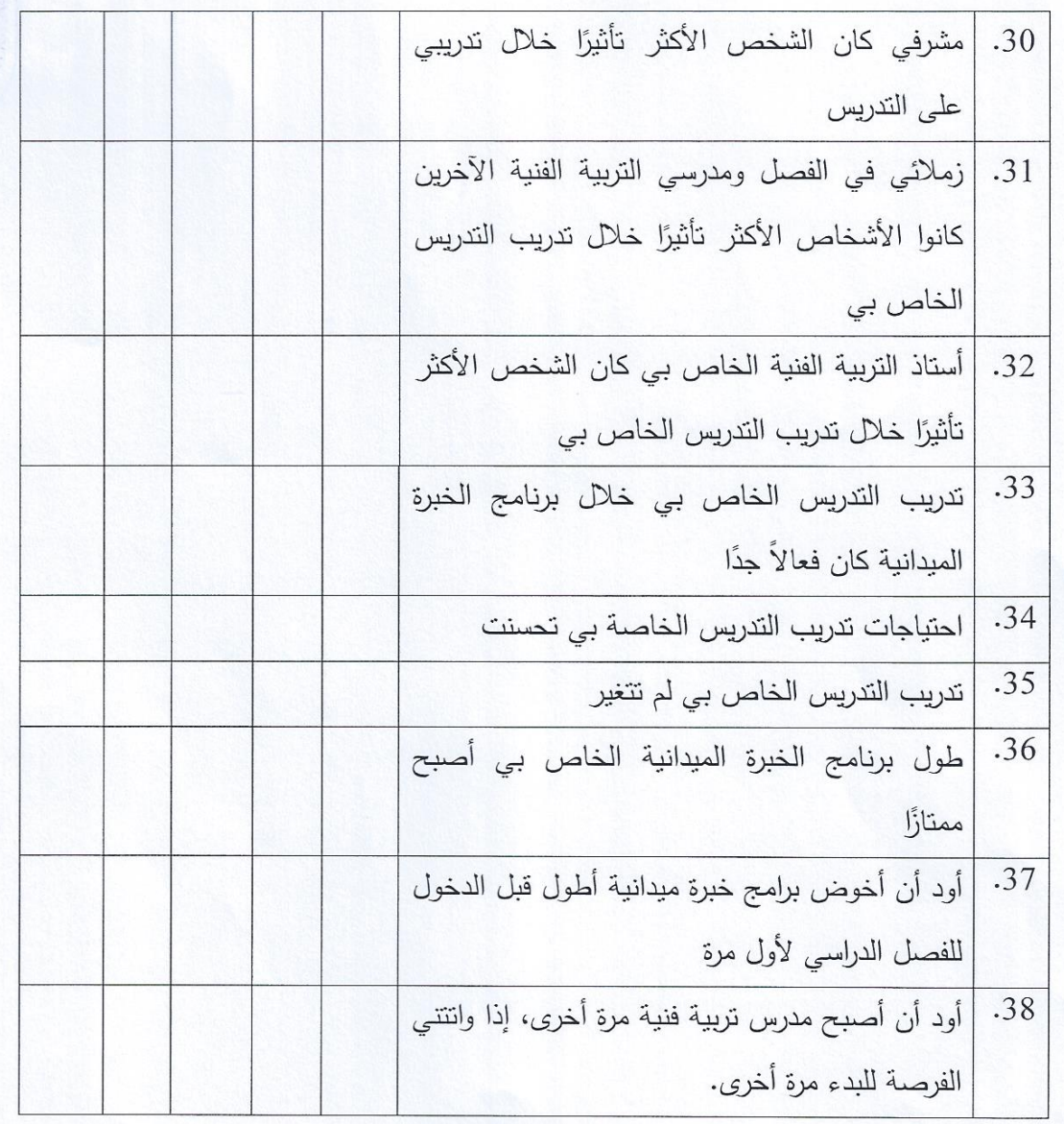
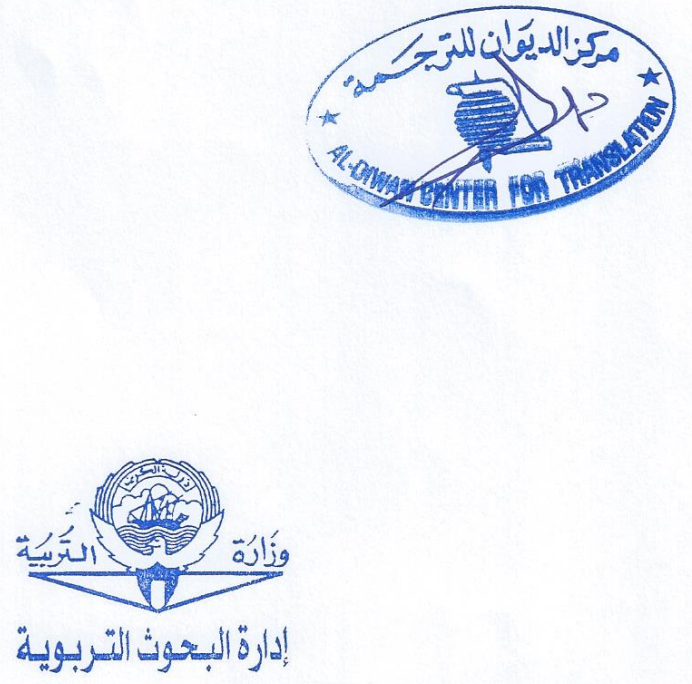


\section{Appendix K}

Arabic Version of the Cover letter Form for both the Pre-Service Art Teachers at the CBE and In-Service Art Teachers at the MOE in Kuwait 


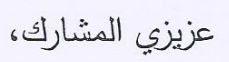

هذا كتاب هو طلبك المشاركة في دشروع بحثي لتحصيل المعلومات المنعلقة بالمفاهيم والميول تجاه تعليم مدرس التربية الفنية وخبرات التدريس من كلية التربية الأساسية لرسالتي البحثية. نم إجراء هذا المشروع من قبل غدير الحداد، في الكويت بإنراف د. جوي ساب، دكتر في كلية التربية بجامعة ويست فرجينيا، للحصول على درجة الدكتراة في التربية. مشاركتك في هذا المشروع تحظى بتقدير بالغ وسيستخرق الأمر 10 دقائق لملء الاستييان المرفقز مشاركناك في هذا الهشروع سيتم الحفاظ على سريتها بالثكل القانوني. كل البيانات سيتم الإبلاغ عنها بشكل مجمع. يجب أن يكون عمرك على الأقل 18 سنة أو أكبر لتتمكن من المشاركة. لن أسأل عن أية معلومات ثؤدي إلى معرفة هوينك كشارك. مشاركتلك هي مشاركة طوعية بشكل كامل. يمكنك تجنب أي سؤال لا نرغب في الإجابة عليه ويمكنأك التوقف في أي وقت.

نأمل أن تثارك في مشروع البحث هذا، حيث أنه مفبد في تقديم المعلومات التي ستؤدي إلى زيادة المعرفة فيما بتعلق بخبرات التدريب للمدرسين المبندئين. هذه المعرفة تساعد في زيادة فعالية برنامج إعداد ددرسي التربية الفنية في الكويت وسيدعم في تحسين إعداد مدرسي التربية الفنية قبل الخدمة في كلية التربية الأساسية

$$
\text { في دولة الكويت. (CBE) }
$$

شكرًا جزيلاً على وقتاك. للادتفسار على أية أسئلة حول هذا الكتاب أو مشروع البحث، برجاء الاتصال على غدير الحداد على رقم: 8855-777 (724) (البريد الإلكتروني: galhadda@,mix.wvu.edu أو د. جوي فيني، مستشار كلية التربية الفنية والذي يشرف على مشروع البحث هذا، على رقم (3778-293-304)

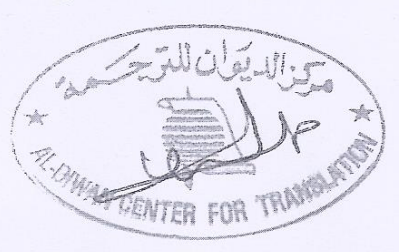




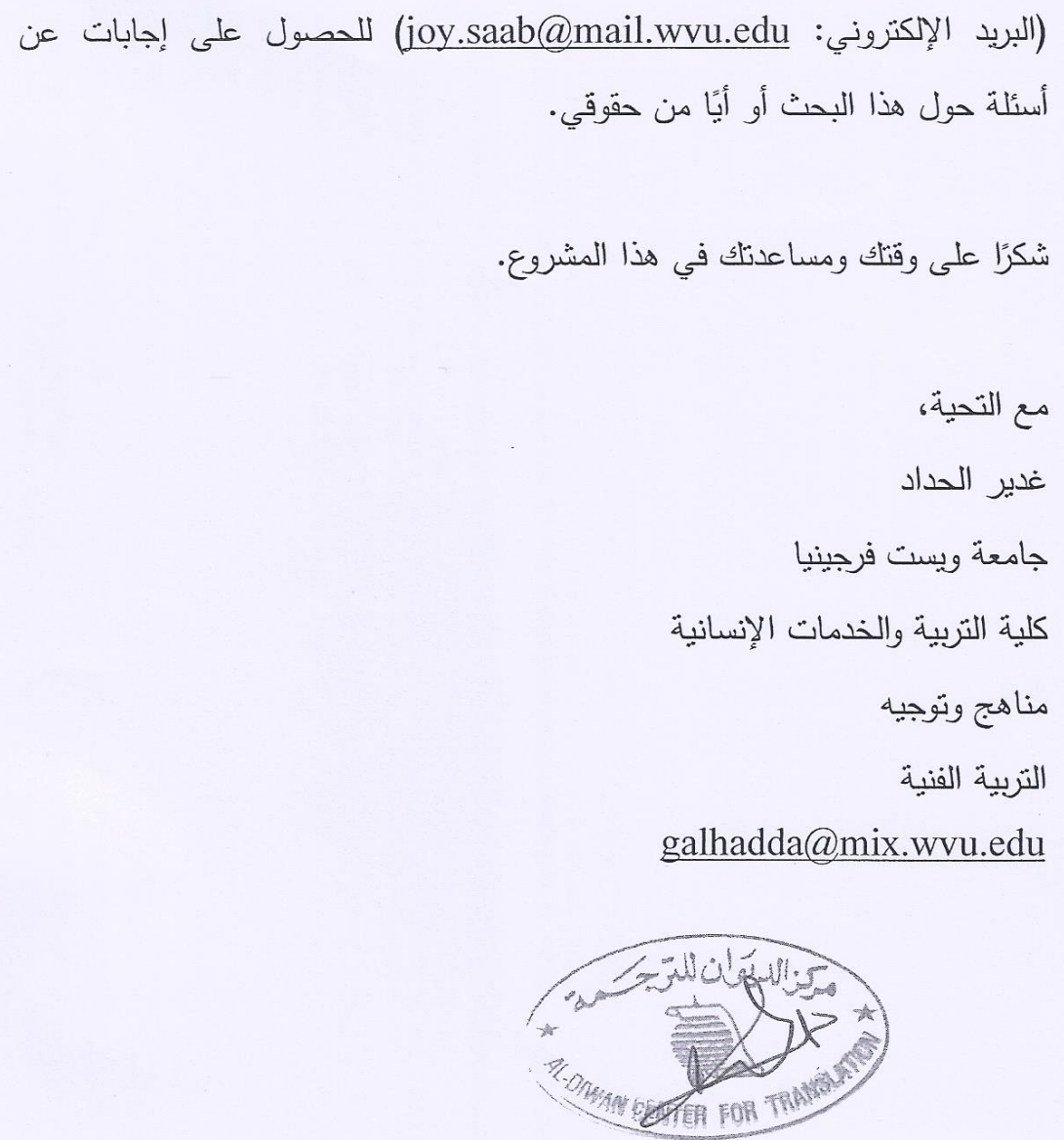




\section{Appendix L}

Arabic Version of the Consent Form for both the Pre-Service Art Teachers at the CBE and In-Service Art Teachers at the MOE in Kuwait 
نموذج موافقة لمدرسي التربية الفنية في الخدمة في وزارة التربية

بحرية وطواعية وبدون إجبار أو فرض، أوافق على أنا المشاركة في المشروع البحثي بحنوان: مفاهيم وميول فعالية برنامج إعداد مدرسي التربية الفنبة في الكويت. أنا أتفهم أن الغرض من المشروع البحثي هو البحث في ميول ومفاهيم مدرسي التربية الفنية الكويثيين في الخدمة وقبل الخدمة بثأن حول فعالية برنامج تعليم مدرس التربية الفنية.

تم إجراء هذا البحث من قبل غدير الحداد، وهي طالبة تخرجت هن قيم التربية في جامعة ويست فربينيا. أنا أتفهم الغرض من مشروع البحث الخاص بها وهو الفهم الأفضل لمفاهيم مدرسي التربية الفنية المبتدئين حول ممارسات التدريس وفعالية برنامج تعليم مدرس التربية الفنية. أنا أتفهم أنه إذا قمت بالمشاركة في المشروع سيتم سؤالي حول مفهومي وميولي تجاه تعليمي كمدر وخبراتي التنريسية. أنا أفهم أن مشاركتي في هذه الدراسة هي لملء الاستبيان المسحي بالمعلومات المتحلقة بالهفاهيم والميول حول تعليم المدرس وخبراتي التبريسية. أن على دراية أن هذا الاستبيان سيستخرق حوالي 10 دقائق لإكمالله.

أنا أتقهم أن هنالك فوائد من المشاركة في هذا المشروع البحثي. أولاً، وعيب الخاص بممارسات التدريس سبزيد. كذلك، سأقدم المعلومات التي تؤدبي إلى زيادة المعرفة الكتعلقة بخبرات التدربس للمدرسين المبتدئين. هذه المعرفة يمكن أن تساعد على زيادة فلعالية برنامج إعداد ددرس التربية الفنية في الكويت وستساعد في تحسين إعداد مدرسي التربية الفنبة قبل الخدمة في كلبة التربية الأساسية (CBE) في دولنة

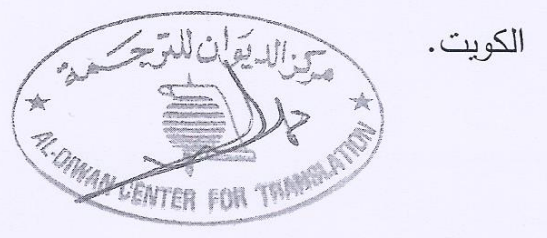


أنا أتقهم أن مشاركتي طوعية بالكامل وأنه يمكنتي أن أثوقف عن المشاركة والانسحاب في أي وقت بدون أذى أو جزاء، ولا يوجد مخاطر متوقعة، إذا وافقت

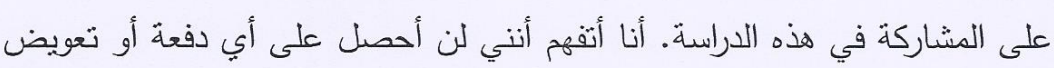
آخر مقابل مشاركتي في هذه الدراسة.

أنا أفهم أن الباحث في مكان آمن سيحافظ على هذا الاستبيان وإجاباتي. إضافة إلى ذللك، كل إجاباتي والردود الكتابية ستحفظ في سرية وسيتم تحديدها برقم كودي. كذلك

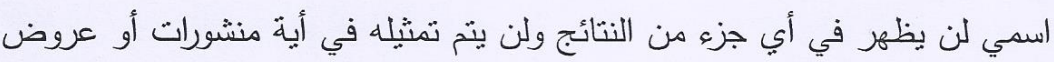
فيما يتعلق بالدراسة. كذلك أنا أدرك أن الباحث ستكون لايه هذه البيانات، وسيتم تدميرها بحلول 20 مايو 2014.

حصلت على حق السؤال وأجبت على أي استفسار ينعلق بالدراسة. وقد تم الإجابة

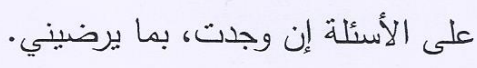

أنا أفهم أن جهة اتصال غدير الدداد هو 8855-777 (724) (البريد الإلكتروني: (galhadda@mix.wvu.edu أو د. جوي فياني ساب، دسنتشار كلية التربية الفنية وهو يشرف على مشُروع البحث هذا، على رقم (3778-293-304) (البريد

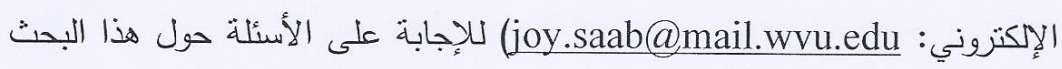

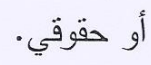

أنا أفهر هذه الدراسة البحثية تمت مراجعتها واعتمادها من قبل مجلس المراجعة

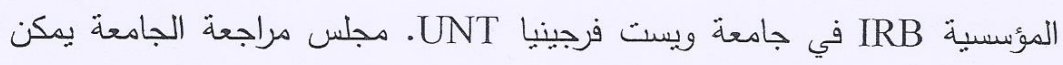

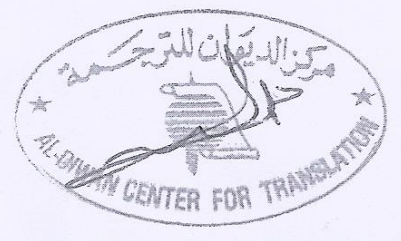




$$
\text { بحقوق عينات البحث. عليه على رقم (7073-293-304) للاستقسار عن أبة أسئلة فيما يتعلق }
$$

وقد قرأت وفهمت نموذج الموافقة هذا.

$$
\text { (اسم المشارك مطبوعًا) (اسمار }
$$

(توقيع وتاريخ المشارك)

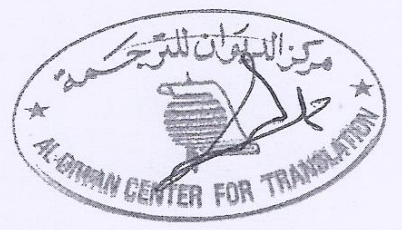


Appendix M

Letter of Confirmation of Translations 


\section{Letter of Confirmation for Translation}

I,

Mohamed Abars

confirm that the translation is correct and not affect the mores of the culture.

\section{Signature}

mohamed Abass

Printed Name

Mohamed Abass

$24 / 8 / 2013$

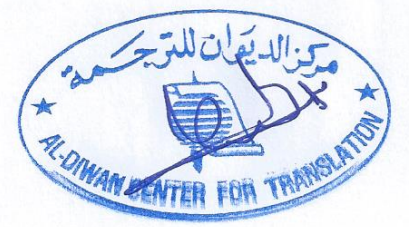




\section{Appendix $\mathrm{N}$}

The CBE Program of Study 


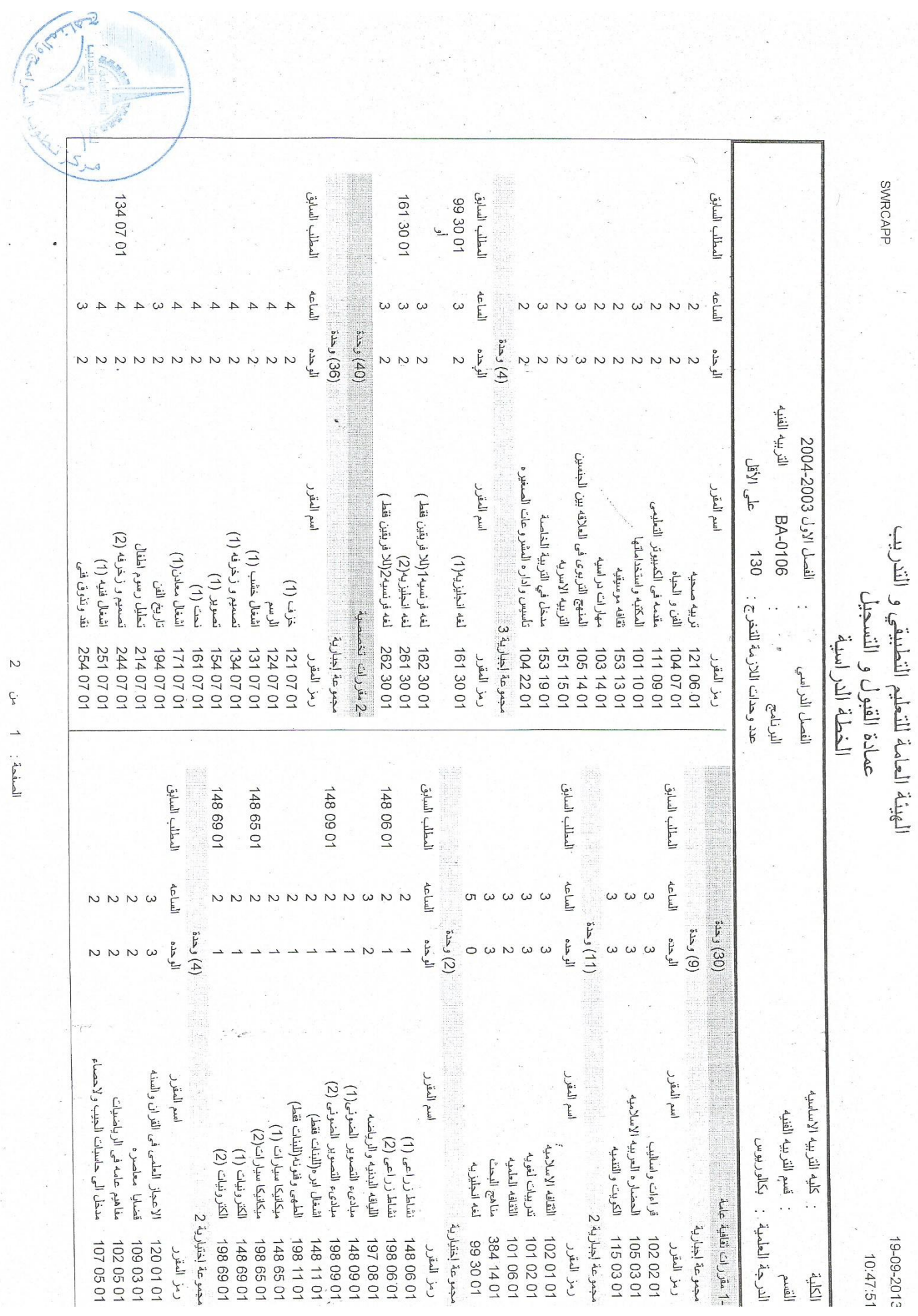




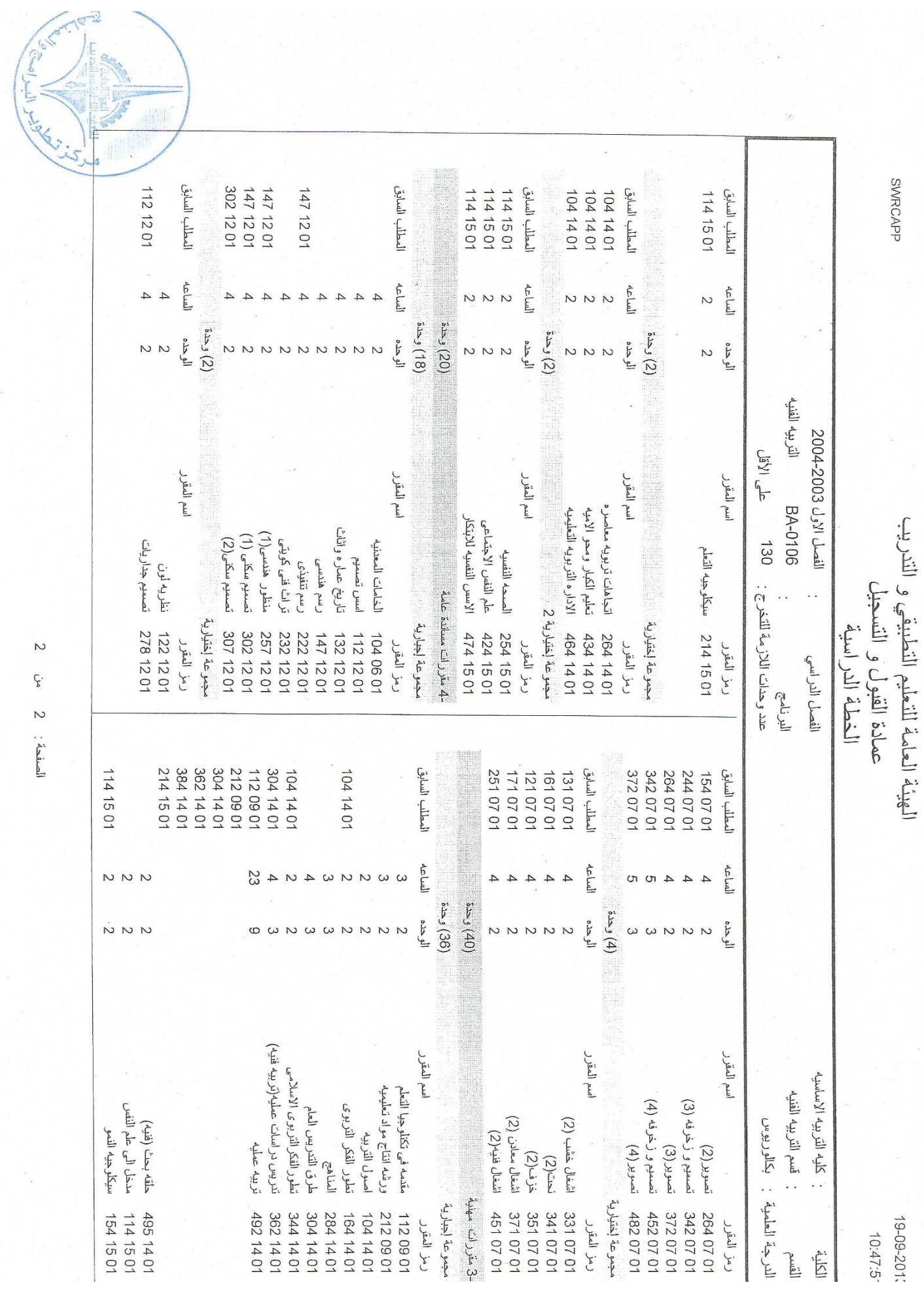




\section{Appendix $\mathrm{O}$}

A Form for The MOE Numbers of Art Teachers for the 2012-2013 


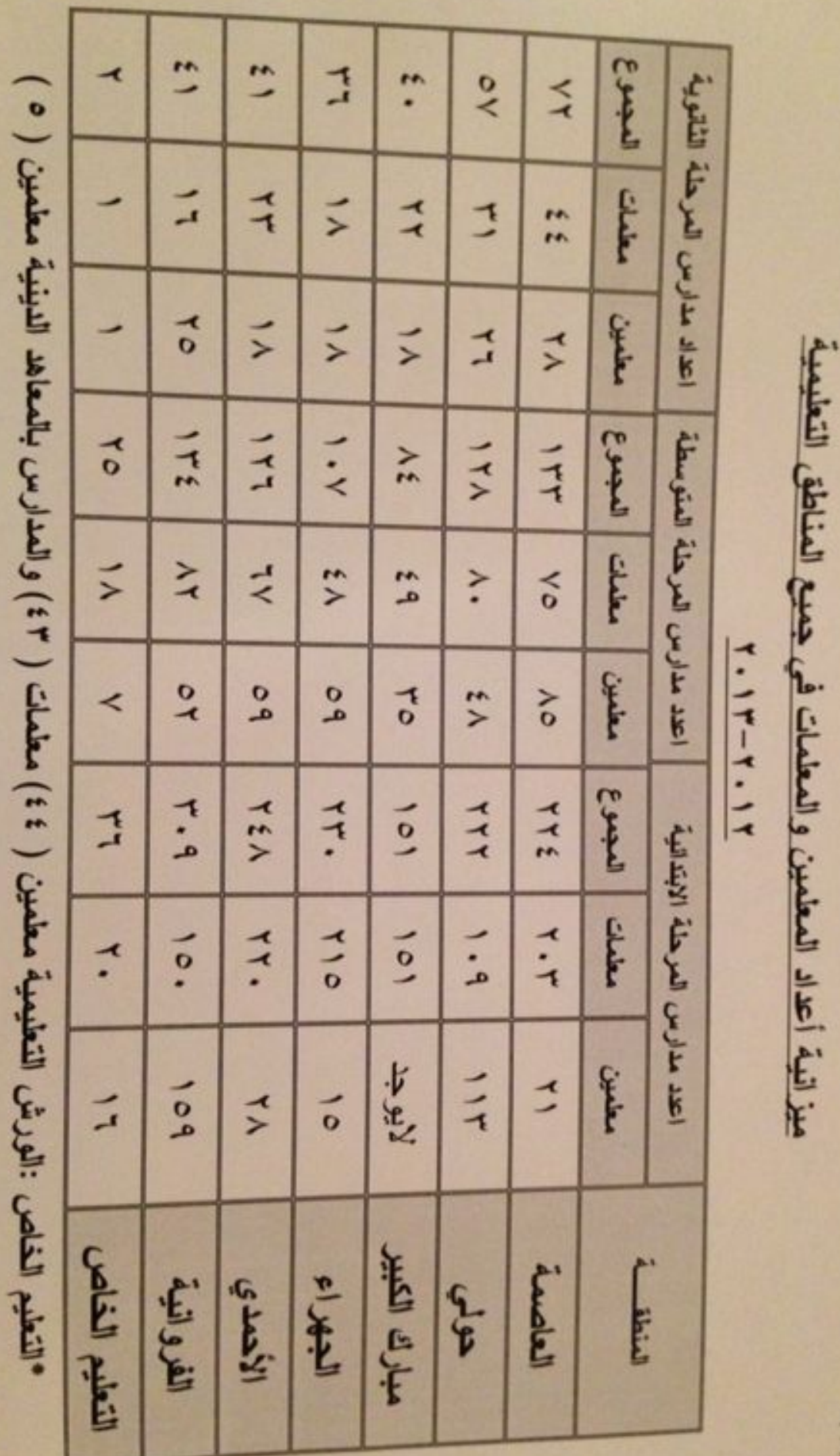

E' 


\section{Appendix $\mathrm{P}$}

A Form for The MOE Numbers of Schools for the 2012-2013 


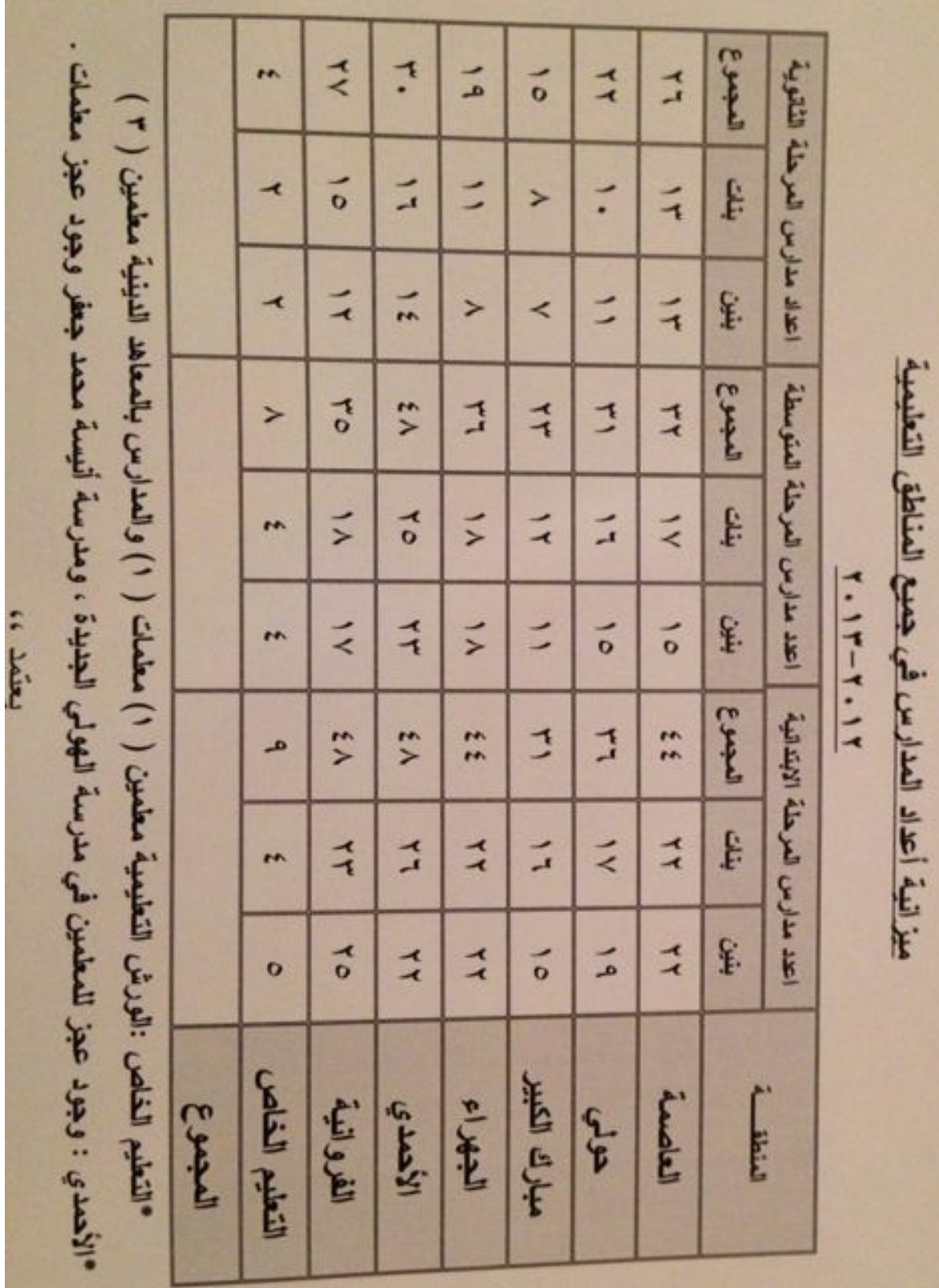




\section{REFERENCES}

Al-Ahmad, A. (1980). Student teacher supervisor effects in preparing teachers, and his future role in the future College of Education at Kuwait University. Journal of Gulf and Arabic Island Studies, 6 (24), 57-71. Bufarsan, 2000).

Al-Ahmad, A. (1986). The development of general education system in the state of Kuwait. Kuwait: Al-Arqum.

Al-Amri , M. (2010). Evaluating art studio courses at sultan Qaboos University in Light of the Discipline Based Art Education Theory. Journal of Instructional Pedagogies, 2(3), Retrieved from http://www.aabri.com/jip.html

Al-Enezi, W. S. (1999). The Development of Art Education in Elementary Schools in Formal Education in Kuwait (1912-1997). Dissertation Abstract International, University of Pittsburgh. Retrieved September 5. 2012 from PROQUESTMS Pennsylvania ProQuest Dissertations \& Theses (PQDT).

AL-Mass, F. (1999). Evaluating the Potential for a Computer Graphic Design Program for the College of Basic Education in Kuwait. Dissertation Abstract International, The Florida State University. Retrieved September 5. 2012 from PROQUESTMS FloridaProQuest Dissertations \& Theses (PQDT).

Al-Muhanna, A. M. (1989). Toward a strategy for implementing discipline based art education in Kuwait. Unpublished doctoral dissertation, Florida State University, Tallahassee.

Al-Najar, A. (2001). A study of first and second year Kuwaiti elementary art teachers' perception of their professional preparation. Unpublished doctoral dissertation, University of Missouri, Columbia.

Al-Najdi, K. (2001). Reforming Arabic calligraphy for computer art and design in Kuwaiti art education. Unpublished doctoral dissertation, Pennsylvania State University, University Park.

Al-Sayegh, A. (1998). Developing an Islamic Geometric Design Course for the Department of Art Education at the College of Basic Education in Kuwait. Dissertation Abstract International, University of Maryland College Park. Retrieved September 5. 2012 from PROQUESTMS. MarylandProQuest Dissertations \& Theses (PQDT).

Arnold, R. (1976). The State of Teacher Education: An Analysis of Selected Art Teacher Preparation Programs in the United States: 1975. Art Education. 29(2), 27-29. 
Art education-Kuwait. (2009). Retrieved from http://www.arteducation-kw.net/1.html

Babbie, E. (1995). The Practice of Social Research (Seventh ed.). Belmont, Cal.: Wadsworth Publishing Co.

Beudert, L. (2006). Work, pedagogy and change: foundations for the art teacher educator. Reston. VA: National Art Education Association.

Blackman, C. R., \& etc. (1977). Louisiana Public School Art Teachers: Profile, Preparation, and Opinions. (Research Report Volume 7, No. 7). Baton Rouge, La.: Louisiana State University.

Bowen, G. A. (2009). Document analysis as a qualitative research method. 9(2), 27-40.

Boyd, D., Grossman, P., lankford, H., Loeb, S., \& Wyckoff, J. (2009). Who leaves? teacher attrition and student achievement. National Center For Analysis of Longitudinal Data in Education Research, CALDER Working Paper(23), Retrieved from http://www.urban.org/UploadedPDF/1001270_teacher_attrition.pdf

Brimfield. R., \& Leonard, R. (1983). The student teaching experience: A time to consolidate one's perceptions. College Student Journal, 77,401-406.

Bufarsan, F. A. (2000). Curriculum Analysis in Teacher Preparation Programs at the College of Basic Education in Kuwait. Dissertation Abstract International, University of North Texas. Retrieved September 16. 2012 from PROQUESTMS TexasProQuest Dissertations \& Theses (PQDT).

Buouyan, S. (1999). Evaluation of the Islamic Education Teacher Preparation Programme in the College of Basic Education in Kuwait. Thesis submitted to the University of Manchester for the degree of Doctor of Philosophy in the Faculty of Education.

Buldu, N. (2005). Attitudes of Pre-Service Elementary Teachers Towards Science: A Cross-National Study between the United States of America and Turkey. Indiana University, 2005. United States. Retrieved October, 12. 2012 from IndianaProQuest Dissertations \& Theses (PQDT).

Bullock, A. L. \& Galbraith, L. (1992). Images of Art Teaching: Comparing the Beliefs and Practices of Two Secondary Art Teachers. Studies in Art Education. 33 (2), 86-97.

Burton, D. (2001). How Do We Teach? Results of a National Survey of Instruction in Secondary Art Education. Studies in Art Education. 42 (2), 131-145. 
Chapman, L. (1979). Teacher Viewpoint Survey: The Results. School Arts, 78(9), 2-5.

Creswell, J. W., \& Plano Clark, V. L. (2007). Designing and conducting mixed methods research. Thousand Oaks, CA: Sage Publications, Inc

College of Basic Education Manual. (2003/2004). Art education program. Kuwait: Public Authority for Applied Education and Training Press. (In Arabic).

Cooper, J., \& Alvarado, A. (2006). Preparation, recruitment, and retention of teachers. Education policy booklet series, 5. Retrieved from http://www.iiep.unesco.org

Cramer, E. S. (2008). Practice Makes Teachers: Affordances and Constraints of an Art Education Field Experience Program. Dissertation Abstract International, University of Kentucky. Retrieved September 16. 2012 from PROQUESTMS KentuckyProQuest Dissertations \& Theses (PQDT).

Darling-Hammond, L. (1992). Teaching and knowledge: Policy issues posed alternative certification for teachers. Peabody Journal of Education, 67(3), 123-154.

Darling-Hammond, L. (1998). Teacher learning that supports student learning. Educational Leadership, 55(5), 6-l.

Darling-Hammond, L., \& MacDonald, M. B. (2000). Where there is learning there is hope: The preparation of teachers at the Bank Street College of Education. In L. Darling-Hammond (Ed.), Studies of excellence in teacher education: Preparation at the graduate level, pp. 1-95. Washington, DC: American Association of Colleges for Teacher Education.

Darling-Hammond, L. and Bransford, J. (Eds.) (2005). Preparing Teachers for a Changing World: What Teachers Should Learn and Be Able to Do. National Academy of Education, Committee on Teacher Education. San Francisco: Jossey Bass, Inc., 12.

Darling-Hammond, L. Powerful Teacher Education: Lessons from Exemplary Programs. (2006). San Francisco: John Wiley and Sons, Inc. 21.

Darling-Hammond, L. (2007). A good teacher in every classroom: Preparing the highly qualified teachers our children deserve. Educational Horizons, 85(2), 111-132.

Darling-Hammond, L., Chung, R., \& Frelow, F. (2002). Variation in teacher preparation: how well do different pathways prepare teachers to teach? Journal of Teacher Education, 53(4), 286-302.

Darling-Hammond, L., Cobb, V. L., Asia Pacific Economic Cooperation Secretariat, (Singapore), \& Department of Education, W. y. (1995). Teacher Preparation and Professional Development in APEC Members: A Comparative Study. 
Darweesh, A. H. (2010). The Enameling Arts in Kuwaiti Pre-Service Art Teacher Education. Dissertation Abstract International, University of North Texas. Retrieved September 5. 2012 from PROQUESTMS TexasProQuest Dissertations \& Theses (PQDT).

Davis, J. D. (1990). Teacher education for the visual arts. In R. Houston (Ed.), Handbook of research on teacher education (pp. 746-757). New York: Macmillan.

Day, M. (1997). Preparing Teachers of Art for the Year 2000 and Beyond. In M. Day (Ed.), Preparing Teachers of Art (pp. 3-26). Reston, Va.: National Art Education Association.

Degge, R. M. (1987). A Descriptive Study of Community Art Teachers with Implications for Teacher Preparation and Cultural Policy Studies in Art Education. 28 (3), 164175.

Dewey, J. (1902). The child and the curriculum. Chicago, IL: University of Chicago.

Dodds, P. (1985). Trainees field experience and socialization into teaching. In T. J. Templin, \& P. G. Schempp (Eds.), Socialization in physical education: Learning to teach (pp. 81-104).

Duncum, P. (2003). Why not visual culture. National Art Education Association, 56(2), 25-32.

Duru, S. (2006). Pre-Service Elementary Education Teachers' Beliefs about Teaching and Learning in Turkey. Indiana University. United States. Retrieved October, 12. 2012 from IndianaProQuest Dissertations \& Theses (PQDT).

Eisner, Elliot W. (2002). The Arts and the Creation of Mind. New Haven, CT: Yale University Press.

Fereday, J, \& Muir-Cochrance, E. (2006). Demonstrating rigor using thematic analysis: A hybrid approach of inductive and deductive coding and theme development. International journal of qualitative methods, 5(1), 80-92.

Freedman, K. (2003). Teaching visual culture: Curriculum, aesthetics, and the social life of art. New York: Teachers College Press.

Fenimore-Smith, J. (2004). Democratic practices and dialogic frameworks: Efforts toward transcending the cultural myths of teaching. Journal of Teacher Education, 55(5), 227-239.

Galbraith, L. (1990). Examining issues from general teacher education: Implications 
for preservice art education methods courses. Visual Arts Research, 16(2), $51-58$.

Galbraith, L. (1995). The Preservice Art Education Classroom: A Look Through the Window. In L. Galbraith (Ed.), Preservice Art Education: Issues and Practices. Reston, Va.: National Art Education Association.

Galbraith, L. (1997). What Are Teachers Taught? An Analysis of Curriculum Components for Art Teachers Preparation Programs. In M. Day (Ed.), Preparing Teachers of Art (pp. 45-72). Reston, Va.: National Art Education Association.

Goldhaber, D. (2006). Everyone's Doing It, But What Does Teacher Testing Tell Us About Teacher Effectiveness? http://www.crpe.org. Center on Reinventing Public Education. Paper presented at the AERA annual meeting April 4, 2006, 31.

Grauer, K. (1998). Beliefs of Preservice Teachers toward Art Education. Studies in Art Education, Vol. 39(4), 350-370.

Grieco, A. P. (2011). Exploring the Early Field Experience to Examine the Impact on Pre-Service Teacher Development. Indiana University of Pennsylvania. United States. Retrieved October 18. 2012 from PennsylvaniaProQuest Dissertations \& Theses (PQDT).

Grossman, P. L. (1989). Learning to teach without teacher education. Teachers College Record, 91(2), 191-208.

Hammond, L. D., \& Bransford, J. (2001). Preparing Teachers for A Changing World . San Francisco, CA : Jossey Bass A Wiley Imprint.

Hanes, J. M., \& Schiller, M. (1994). Collaborating with cooperating teachers in Pre-service art education. Studies in Art Education, 35(4), 218-228.

Harrell, L. A. (2007). Beginning art teachers in Florida: Perceptions of their preparation to teach art. The Florida State University. Retrieved October 18. 2012 from FloridaProQuest Dissertations \& Theses (PQDT).

Harting-McChesney, J. (2008). Learning from Two First Year Teachers: Reflections of a Teacher Educator. Hofstra University. United States. Retrieved October 18. 2012 from New YorkProQuest Dissertations \& Theses (PQDT).

Henry, C. (2007). Changing Teacher Preparation in Art Education. Art Education, $60(1), 47-51$.

Hsieh, H., \& Shannon, S. (2005). Three approaches to qualitative content analysis. Qualitative Health Research, 15(9), 1277-1288. 
Hogg, J. C. (1982). A study of the influence on the attitude formation process of fine art majors. Unpublished doctoral dissertation, Ohio State University, Columbus.

Hoover, J. J. (1986). The preparation of regular class elementary teachers for education of exceptional children: An emphasis upon knowledge, attitudes, and skills. Educational Research Quarterly, 10(3), 2-7.

Hovanec, J. L. (2011). Who Art I? A Phenomenological Study of Reflective Practice, Professional Identity Construction, and Student Teaching. Dissertation Abstract International, Capella University. Retrieved September 16. 2012 from PROQUESTMS MinnesotaProQuest Dissertations \& Theses (PQDT).

Hutchens, J. (1997). Accomplishing Change in the University: Strategies for Improving Art Teacher Preparation. In M. Day (Ed.), Preparing Teachers of Art (pp. 139-154). Reston, Va.: National Art Education Association.

Jaeger, R. M. (1997). Survey research methods in education. In R. M. Jaeger (Ed.), Complementary methods for research in education (2nd ed.). Washington, D.C.: American Educational Research Association.

Jeffers, C. S. (1996). Professional Development in Art Education Today: A Survey of Kansas Art Teachers. Studies in Art Education, 37(2), 101-114.

Jelmberg, J. R. (1996). College based teacher education versus state sponsored alternative programs. Journal of Teacher Education , 47, 60-66.

Jones, A. G. The Transition of Visual Arts Education in the United States into the Twenty-First Century, and the Implications for this Transition from John Dewey's Philosophy of Art Experience. Dissertation Abstract International, University of the Incarnate Word. . Retrieved September 16. 2012 from PROQUESTMS TexasProQuest Dissertations \& Theses (PQDT).

Kowalchuk, E. (1999). Perceptions of practice: What art students say they learn and need to know. Studies in Art Education, 41(1), 71-90.

Kvale, S \& Brinkmann, S. (2009). Interviews. Learning the craft of qualitative research intervening. SAGE.

LCB Coordinators. (2005, Spring). Arts in education definitions. Retrieved from http://www.earts.org/usr/AIE_Definitions.pdf

Lim, E. H. (2008). Studio art practices and K--12 art teachers' identities: Pedagogy, art curricula, and professional discourses.

Northern Illinois University. Retrieved October 18. 2012 from IllinoisProQuest Dissertations \& Theses (PQDT) 
Lui, W. (2003). Preservice teachers' reflections on student teaching experiences: Lessons learned and suggestions for reform in PETE programs. The Physical Educator, $60\{2), 2-12$.

McDermott, M. (2002). Collaging preservice teacher identity. Teacher Education Quarterly, 29\{4), 53-68.

Merriam, S. B. (1988). Case study research in education: A qualitative approach. San Fransisco:Jossey-Bass.

Milbrandt, M. K. (2006). A Collaborative Model for Art Education Teacher Preparation. Arts Education Policy Review, 107(5), 13-21.

Milbrandt, M. K., \& Klein, S. R. (2008). Survey of Art Teacher Educators: Qualifications, Identity, and Practice. Studies In Art Education, 49(4), 343-357.

Mohammad, A. (2007). An Examination of the Perceived Need and Recommended Body of Knowledge for Architectural Internship Programs in Kuwait. Dissertation Abstract International, Texas A\&M University. Retrieved September 5. 2012 from PROQUESTMS TexasProQuest Dissertations \& Theses (PQDT).

Monsivais, G. (1990). Latino teachers: Well educated but not prepared. Informally published manuscript, Tomas Rivera Center, Tomas Rivera Center, Claremont, CA, Available from ERIC. (ED372887).

Morse, J. M. (1991). Approaches to qualitative-quantitative methodological triangulation. Nursing Research, 40, 120-123.

Murphy, P. Delli, L. M., \& EdwardsReviewed, M. N. (2004). The Good Teacher and Good Teaching: Comparing Beliefs of Second-Grade Students, PreserviceTeachers, and Inservice Teachers. The Journal of Experimental Education, 72(2), 69-92.

National Art Education Association. (2009). Standards for art teacher preparation. Retrieved from http://www.arteducators.org/research/sabol_pro_dev_report.pdf

NCRTL. (1992). Findings from the Teacher Education and Learning to Teach study: Final report, the National Center for Research on Teacher Education. 96 pp.

Ortiz, C. (2008). A Self-Exploration of the Relationship between Art Teaching and Artistic Practice. Dissertation Abstract International, University of Houston. . Retrieved September 16. 2012 from PROQUESTMS TexasProQuest Dissertations \& Theses (PQDT).

Paaet-kuwait. (2013). Retrieved from Art education-Kuwait. Retrieved from http://www.arteducation-kw.net/1.html 
Sabol, E R. (2004). An overview of art teacher recruitment, certification, and retention, In E. Eisner \&M. Day (Eds.), Handbook of research and policy in art education (pp. 523-551). Mahwah, NJ: Lawrence Erlbaum Associates.

Sabol, F. R. (2006). Professional development in art education: A study of needs, issues, and concerns of art educators. Informally published manuscript, Purdue University, Purdue University, West Lafayette, Indiana, Retrieved from http://www.arteducators.org/research/sabol_pro_dev_report.pdf

Seidman, I. (1998). Interviewing as Qualitative Research. New York: Teachers College Press.

Shen, J. (2003). New teachers' certification status and attrition pattern. A survival analysis using the Baccalaureate and Beyond Longitudinal Study 1993-97. Paper presented at the AERA annual meeting, Chicago.

Smith, K. J. (2010). A Qualitative Case Study Exploring the Impact of Experienced Teachers' Stories on Pre-Service Teachers. The University of North Carolina at Chapel Hill. United States. Retrieved October 18. 2012 from North CarolinaProQuest Dissertations \& Theses (PQDT).

Sonquist, J. A., \& Dunkelberg, W. C. (1977). Survey and opinion research: Procedures for processing and analysis. Englewood Cliffs, NJ: Prentice-Hall, Inc.

Stuckhardt, M. H. (1976). The development of a scale to measure attitudes held toward the visual arts. Unpublished doctoral dissertation, University of Illinois, Urbana.

Susi, F. (1992). Using clinical supervision techniques with student art teachers. Art Education, 45(6), 45-51.

Thurber, E. (2004). Teacher education as a field of study in art education. In E. Eisner \& M, Day (Eds.), Handbook of research and policy in art education (pp. 415-4.17). Mahwah, Nf: Lawrence Erlbaum Associates.

Unrath, K., \& Kerridge, D. (2009). Becoming an Art Teacher Storied Reflections of Two Preservice Students. Studies in Art Education, 50(3), 272-286.

U.S. Department of Education. (2007, June). The condition of education 2007. Retrieved from http://nces.ed.gov/pubs2007/2007064.pdf

Vance, F. (1989). Attitude toward and knowledge about art: A survey of public elementary school principles. Unpublished doctoral dissertation, Illinois State University, Normal. 
Wilson, Suzanne M., Floden, Robert E., and Ferrini-Mundy, Joan. (2001) Executive Summary: Teacher Preparation Research: Current Knowledge, Gaps, and Recommendations. Center for the Study of Teaching and Policy, University of Washington in collaboration with Michigan State University, 2. Prepared for the U.S. Department of Education's Office for Educational Research and Improvement. The report is available at http://depts.washington.edu/ctpmail.

Yost, D. (1997). The moral dimensions of teaching and pre-service teachers: Can moral dispositions be influenced? Journal of Teacher Education, 48\{A), 281-292.

Zimmerman, E. (1997). Whence Come We? What Are We? Whither Go We? Demographic Analysis of Art Teacher Preparation Programs in the United States. In M. Day (Ed.), Preparing Teachers of Art (pp. 27-44). Reston, Va.: National Art Education Association.

Zimmerman, E. (2004). Introduction to teaching and teacher education. In E. Eisner \& M. Day (Eds.). Handbook of research and policy in art education (pp. 409-413). Mahwah, NJ: Lawrence Erlbanm Associates. 